Prepared in cooperation with the Stanislaus and Tuolumne Rivers Groundwater Basin Association

\title{
Hydrologic Model of the Modesto Region, California, 1960-2004
}

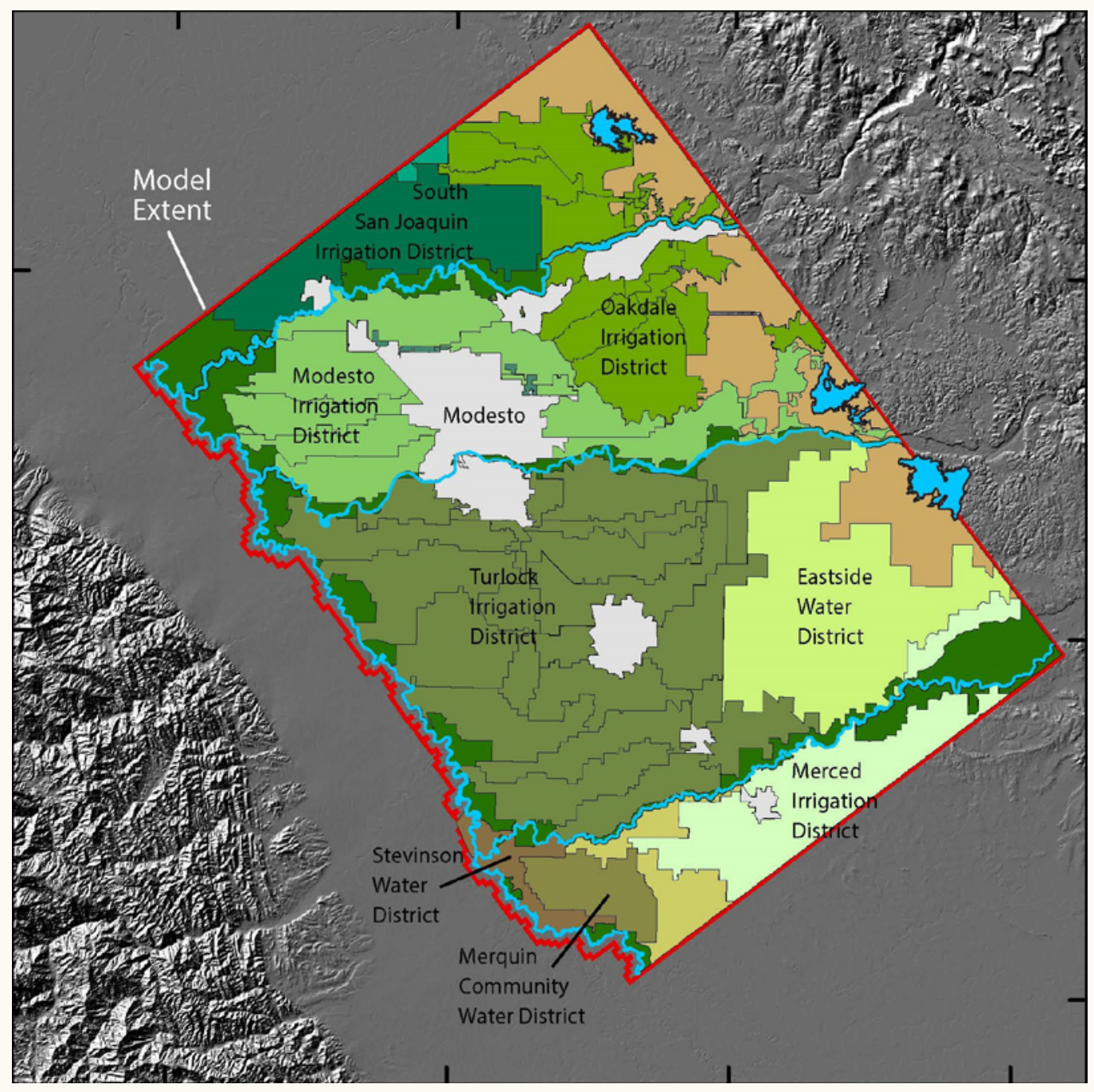

Scientific Investigations Report 2015-5045 



\section{Hydrologic Model of the Modesto Region, California, 1960-2004}

By Steven P. Phillips, Diane L. Rewis, and Jonathan A. Traum

Prepared in cooperation with the Stanislaus and Tuolumne Rivers Groundwater

Basin Association

Scientific Investigations Report 2015-5045 


\title{
U.S. Department of the Interior SALLY JEWELL, Secretary
}

\section{U.S. Geological Survey Suzette M. Kimball, Acting Director}

\author{
U.S. Geological Survey, Reston, Virginia: 2015
}

For more information on the USGS - the Federal source for science about the Earth, its natural and living resources, natural hazards, and the environment-visit http://www.usgs.gov or call 1-888-ASK-USGS.

For an overview of USGS information products, including maps, imagery, and publications, visit http://www.usgs.gov/pubprod/.

Any use of trade, firm, or product names is for descriptive purposes only and does not imply endorsement by the U.S. Government.

Although this information product, for the most part, is in the public domain, it also may contain copyrighted materials as noted in the text. Permission to reproduce copyrighted items must be secured from the copyright owner.

Suggested citation:

Phillips, S.P., Rewis, D.L., and Traum, J.A., 2015, Hydrologic model of the Modesto Region, California, 1960-2004:

U.S. Geological Survey Scientific Investigations Report, 2015-5045, 69 p., http://dx.doi.org/10.3133/sir20155045. 


\section{Acknowledgments}

The authors gratefully acknowledge the financial, technical, and data contributions to this study from the members of Stanislaus and Tuolumne Rivers Groundwater Basin Associationthe cities of Modesto, Oakdale and Riverbank; Modesto and Oakdale Irrigation Districts; and Stanislaus County. We also thank Turlock Irrigation District for providing data and technical assistance. 


\section{Contents}

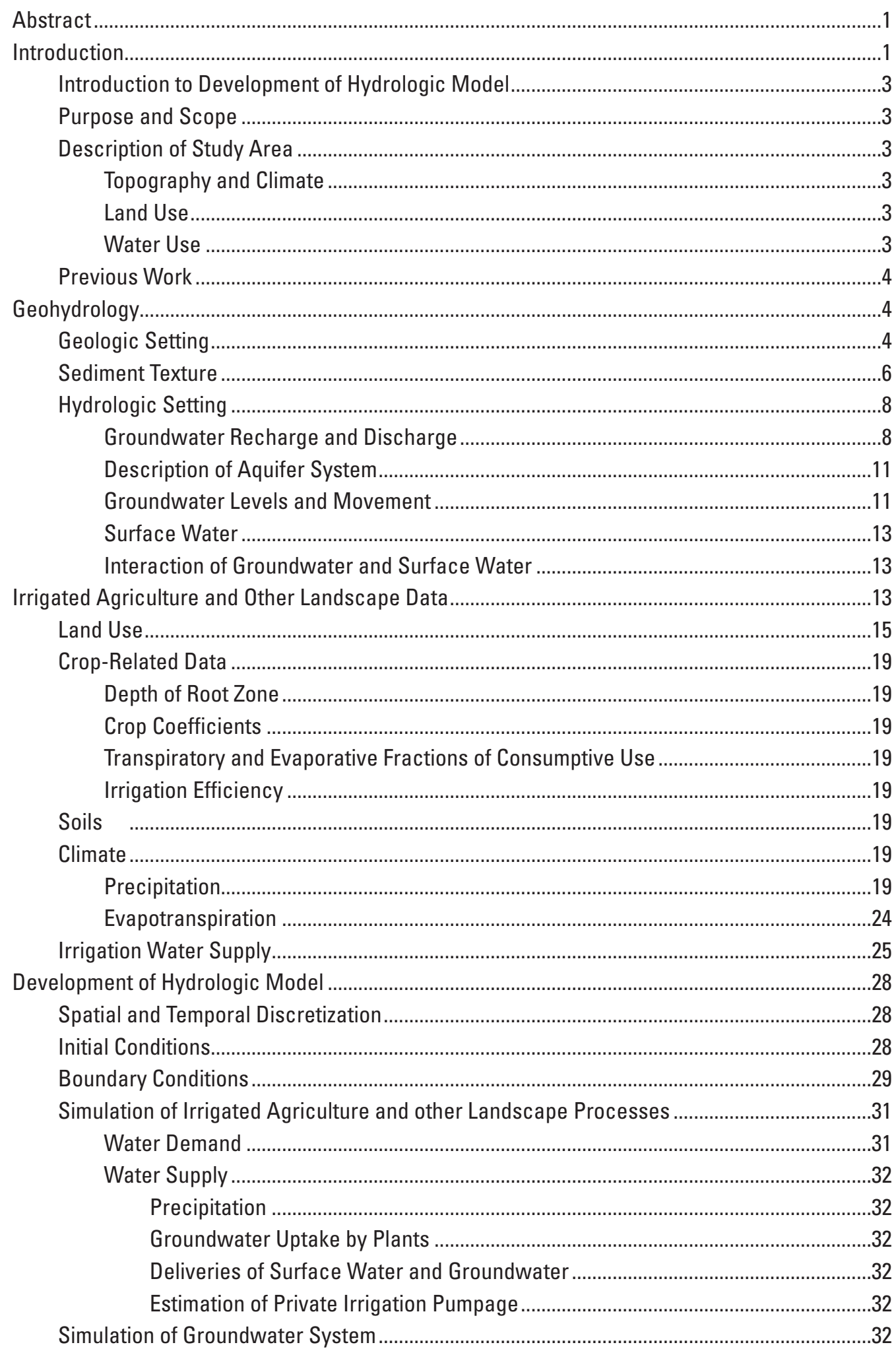




\section{Contents-Continued}

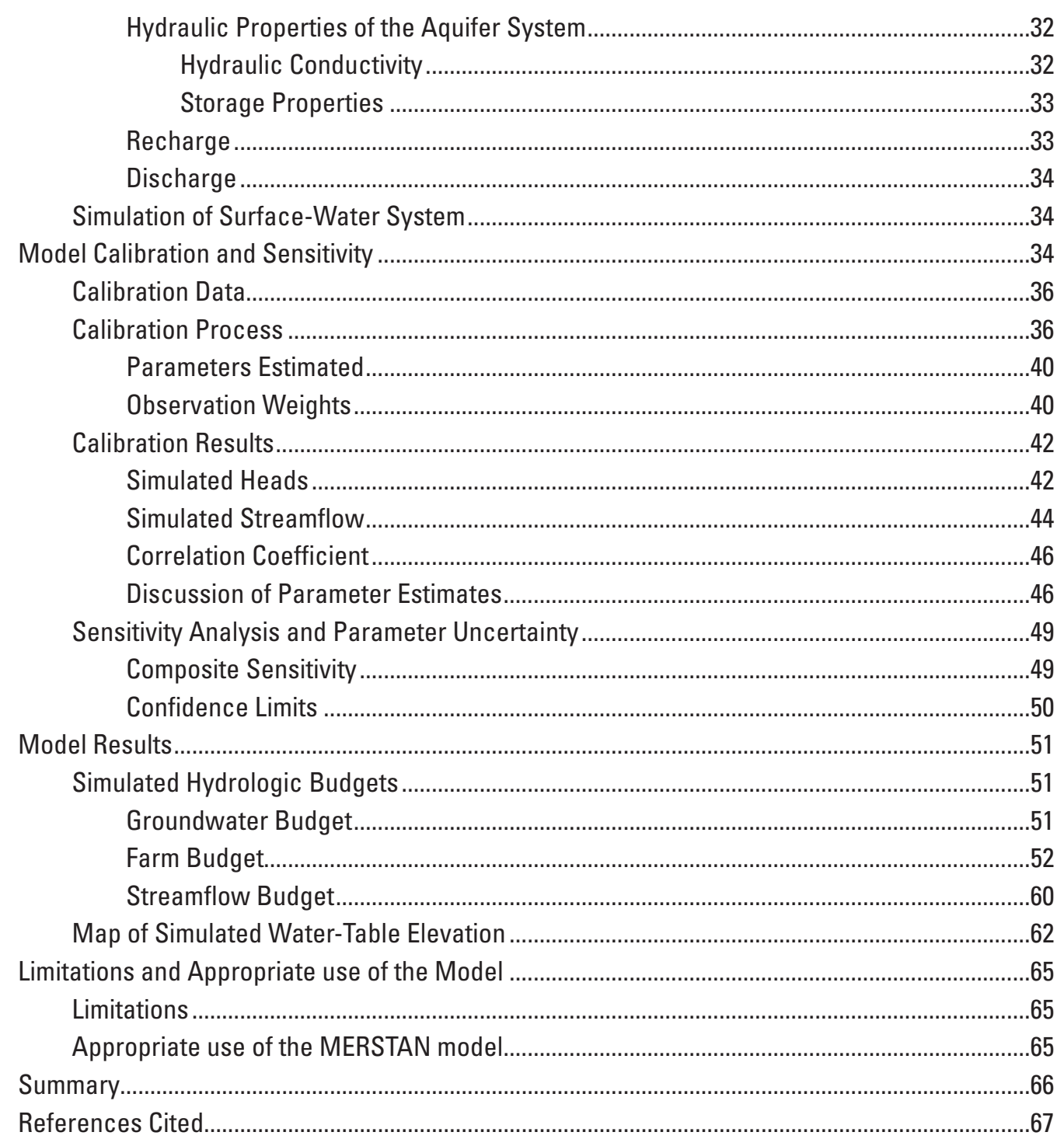

\section{Figures}

1. Map showing location of the Stanislaus and Tuolumne Rivers Groundwater Basin Association (STRGBA) boundary in the study area, Modesto region, California ..............2

2. Map showing selected surficial geologic units in the Modesto region, California............5

3. Images showing two-dimensional slices through a three-dimensional model of the percentage of coarse-grained sediments for the Modesto region, California ..................7

4. Graphs showing measured and estimated urban groundwater pumpage from 1960 to 2004, Modesto region, California: $A$, annual total and $B$, average monthly.

5. Graphs showing agricultural drainage pumpage from 1960 to 2004 for the Modesto (MID) and Turlock (TID) Irrigation Districts, Modesto region, California: $A$, annual total and $B$, average monthly.

6. Map showing contours of measured water-level altitude in the unconfined to semi-confined aquifer, spring 2000, Modesto region, California 


\section{Figures-Continued}

7. Map showing agricultural, natural, and urban areas represented in the MERSTAN model by one or more water-balance subregions, Modesto region, California

8. Map showing estimated distribution of land use in 1960, Modesto region, California

9. Map showing composite circa-2004 land use in the Modesto region, California, based on 1996 (San Joaquin County), 2002 (Merced County), and 2004 (Stanislaus County) land-use data.

10. Graphs showing land use in the Modesto region, California, 1960-2004: $A$, average acreage of crops and other land uses; $B$, time series of acreage for deciduous trees, natural vegetation and riparian, urban, and pasture; $C$, time series of acreage for corn, alfalfa, vineyards and grain; and $D$, time series of acreage for field crops, truck crops, fallow acreage, and rice.

11. Map showing generalized soil distribution for the Modesto region, California...............23

12. Graphs showing annual totals for 1960-2004, Modesto region, California, of $A$, precipitation and $B$, reference evapotranspiration.

13. Graph showing average monthly precipitation and reference evapotranspiration, 1960-2004, Modesto region, California

14. Graphs showing irrigation deliveries, 1960-2004, for the Modesto region, California:

$A$, total annual and $B$, average monthly.

15. Map showing reported irrigation deliveries, converted to rates, for agricultural water-balance subregions of the MERSTAN model that received deliveries, water year 2004, Modesto region, California.

16. Graph showing vertical discretization of MERSTAN model along row 73, Modesto region, California.

17. Map showing boundary conditions for the MERSTAN model, Modesto Region, California

18. Map showing model cells used to represent rivers, and groups of cells representing river reaches, in the MERSTAN model, Modesto Region, California

19. Map showing locations of wells used to calibrate the MERSTAN model, Modesto region, California.

20. Graphs showing heads for the MERSTAN model, Modesto Region, California: $A$, simulated and observed; $B$, residual (simulated - observed) and observed; and $C$, a histogram of residuals

21. Hydrographs showing measured water levels for all wells used to calibrate the MERSTAN model, Modesto region, California, and simulated heads in the model cells most representative of each well

22. Graphs showing comparisons of observed and simulated streamflow from the MERSTAN model, Modesto region, California, 1960-2004: $A$, simulated versus observed streamflow; $B$, residual (simulated - observed) versus observed streamflow; and $C$, a histogram of residual streamflow .

23. Graphs showing observed (symbols) and simulated (lines) stream stage and discharge for selected streamgages on the San Joaquin, Merced, Tuolumne, and Stanislaus Rivers, 1960-2004, Modesto region, California

24. Graphs showing observed and simulated stream discharge for selected streamgages on the San Joaquin, Merced, Tuolumne, and Stanislaus Rivers, 1960-2004, Modesto region, California

25. Graph showing relative composite sensitivities for model parameters estimated for the MERSTAN model, Modesto region, California 


\section{Figures-Continued}

26. Graph showing key components of the simulated groundwater budget, 1960-2004, for the MERSTAN model, Modesto region, California

27. Graph showing simulated farm-budget results, 1960-2004, for the MERSTAN model, Modesto region, California.

28. Graphs showing farm-well (private agricultural) pumpage, 1960-2004, for the MERSTAN model, Modesto region, California: $A$, simulated annual and $B$, average monthly.

29. Map showing average simulated rates of private agricultural pumpage for waterbalance subregions of the MERSTAN model, 1960-2004, Modesto region, California ...55

30. Graphs showing simulated deep percolation for the MERSTAN model, 1960-2004, Modesto region, California: $A$, annual and $B$, average monthly .

31. Map showing simulated deep percolation for the MERSTAN model, 1960-2004, Modesto region, California: $A$, annual and $B$, average monthly.....

32. Map showing simulated percentage of precipitation, groundwater uptake, irrigation delivery, and groundwater pumpage for irrigation, in 2004, for waterbalance subregions of the MERSTAN model, Modesto region, California

33. Map showing simulated percentage of evapotranspiration and deep percolation (groundwater recharge), in 2004, for water-balance subregions of the MERSTAN model, Modesto region, California. The size of each pie chart is proportional to the total volume...

34. Graph showing monthly specified stream inflow for 1960-2004 at the MERSTAN model boundaries for the Stanislaus (SR), Tuolumne (TR), and Merced (MR) Rivers and at the upper end of the San Joaquin (SJR) River; the mean monthly simulated outflow from the model at the lower end of the San Joaquin River; and the difference between the total stream inflows and simulated outflow for the Modesto region, California

35. Graphs showing average simulated stream-cell loss (negative) or gain, 1960-2004, for the Stanislaus, Tuolumne, Merced, and San Joaquin Rivers, MERSTAN model, Modesto region, California.

36. Graphs showing annual simulated stream loss (negative) or gain for the Stanislaus, Tuolumne, Merced, and San Joaquin Rivers, MERSTAN model, Modesto region, California.

37. Map showing contour of the simulated water table during March 2000, MERSTAN model, Modesto region, California

\section{Tables}

1. Crop categories and types, and associated maximum root depths and lowest and highest irrigation efficiencies, specified in the MERSTAN model, Modesto region, California.....

2. Monthly crop coefficients specified in the MERSTAN model, Modesto region, California.

3. Monthly transpiratory fraction of consumptive use (FTR), evaporative fraction of consumptive use related to precipitation (FEP), and evaporative fraction of consumptive use related to irrigation (FEI) specified in the MERSTAN model, Modesto region, California.

4. Monitored wells in the Modesto region, California, used to calibrate the MERSTAN model.

5. Parameters estimated for the MERSTAN model, Modesto region, California 


\section{Tables-Continued}

6. Average annual simulated water budget, $1960-2004$, for the MERSTAN model, Modesto region, California.

\section{Conversion Factors, Datums, and Abbreviations}

\section{Conversion Factors}

Inch/Pound to International System of Units

\begin{tabular}{|c|c|c|}
\hline Multiply & By & To obtain \\
\hline \multicolumn{3}{|c|}{ Length } \\
\hline inch (in.) & 2.54 & centimeter $(\mathrm{cm})$ \\
\hline inch (in.) & 25.4 & millimeter $(\mathrm{mm})$ \\
\hline foot (ft) & 0.3048 & meter $(\mathrm{m})$ \\
\hline mile (mi) & 1.609 & kilometer $(\mathrm{km})$ \\
\hline \multicolumn{3}{|c|}{ Area } \\
\hline acre & 4,047 & square meter $\left(\mathrm{m}^{2}\right)$ \\
\hline acre & 0.4047 & square hectometer $\left(\mathrm{hm}^{2}\right)$ \\
\hline acre & 0.004047 & square kilometer $\left(\mathrm{km}^{2}\right)$ \\
\hline section (640 acres or 1 square mile) & 259.0 & square hectometer $\left(\mathrm{hm}^{2}\right)$ \\
\hline square mile $\left(\mathrm{mi}^{2}\right)$ & 259.0 & hectare (ha) \\
\hline square mile $\left(\mathrm{mi}^{2}\right)$ & 2.590 & square kilometer $\left(\mathrm{km}^{2}\right)$ \\
\hline \multicolumn{3}{|c|}{ Volume } \\
\hline cubic foot $\left(\mathrm{ft}^{3}\right)$ & 28.32 & cubic decimeter $\left(\mathrm{dm}^{3}\right)$ \\
\hline cubic foot $\left(\mathrm{ft}^{3}\right)$ & 0.02832 & cubic meter $\left(\mathrm{m}^{3}\right)$ \\
\hline acre-foot (acre-ft) & 1,233 & cubic meter $\left(\mathrm{m}^{3}\right)$ \\
\hline \multicolumn{3}{|c|}{ Flow rate } \\
\hline acre-foot per day (acre-ft/d) & 0.01427 & cubic meter per second $\left(\mathrm{m}^{3} / \mathrm{s}\right)$ \\
\hline acre-foot per year (acre-ft/yr) & 1,233 & cubic meter per year $\left(\mathrm{m}^{3} / \mathrm{yr}\right)$ \\
\hline acre-foot per year (acre-ft/yr) & 0.001233 & cubic hectometer per year $\left(\mathrm{hm}^{3} / \mathrm{yr}\right)$ \\
\hline foot per day $(\mathrm{ft} / \mathrm{d})$ & 0.3048 & meter per day $(\mathrm{m} / \mathrm{d})$ \\
\hline foot per year (ft/yr) & 0.3048 & meter per year (m/yr) \\
\hline cubic foot per second $\left(\mathrm{ft}^{3} / \mathrm{s}\right)$ & 0.02832 & cubic meter per second $\left(\mathrm{m}^{3} / \mathrm{s}\right)$ \\
\hline cubic foot per day ( $\left.\mathrm{ft}^{3} / \mathrm{d}\right)$ & 0.02832 & cubic meter per day $\left(\mathrm{m}^{3} / \mathrm{d}\right)$ \\
\hline \multicolumn{3}{|c|}{ Hydraulic conductivity } \\
\hline foot per day (ft/d) & 0.3048 & meter per day $(\mathrm{m} / \mathrm{d})$ \\
\hline \multicolumn{3}{|c|}{ Hydraulic gradient } \\
\hline foot per mile $(\mathrm{ft} / \mathrm{mi})$ & 0.1894 & meter per kilometer $(\mathrm{m} / \mathrm{km})$ \\
\hline \multicolumn{3}{|c|}{ Leakance } \\
\hline foot per day per foot $[(\mathrm{ft} / \mathrm{d}) / \mathrm{ft}]$ & 1 & meter per day per meter \\
\hline inch per year per foot $[(\mathrm{in} / \mathrm{yr}) / \mathrm{ft}]$ & 83.33 & millimeter per year per meter $[(\mathrm{mm} / \mathrm{yr}) / \mathrm{m}]$ \\
\hline
\end{tabular}

Temperature in degrees Fahrenheit $\left({ }^{\circ} \mathrm{F}\right)$ may be converted to degrees Celsius $\left({ }^{\circ} \mathrm{C}\right)$ as follows:

${ }^{\circ} \mathrm{C}=\left({ }^{\circ} \mathrm{F}-32\right) / 1.8$. 


\section{Conversion Factors, Datums, and Abbreviations-Continued}

\section{Datum}

Vertical coordinate information is referenced to the North American Vertical Datum of 1988 (NAVD 88).

Horizontal coordinate information is referenced to the North American Datum of 1983 (NAD 83).

Altitude, as used in this report, refers to distance above the vertical datum.

\section{Abbreviations}

$\begin{array}{ll}\text { MID } & \text { Modesto Irrigation District } \\ \text { NAWQA } & \text { National Water Quality Assessment } \\ \text { OPC } & \text { Quaternary Plio-Pleistocene age semi-consolidated } \\ \text { SFR2 } & \text { Streamflow Routing Package, version 2 } \\ \text { STATSGO } & \text { State Soil Geographic } \\ \text { STRGBA } & \text { Stanislaus and Tuolumne Rivers Groundwater Basin Association } \\ \text { TID } & \text { Turlock Irrigation District } \\ \text { USGS } & \text { U.S. Geological Survey } \\ \text { WBS } & \text { water-balance subregions }\end{array}$

\section{Well Numbering System}

Wells are identified and numbered according to their location in the rectangular system for the subdivision of public lands. Identification consists of the township number, north or south; the range number, east or west; and the section number. Each section is divided into sixteen 40 -acre tracts lettered consecutively (except I and 0 ), beginning with " $A$ " in the northeast corner of the section and progressing in a sinusoidal manner to " $R$ " in the southeast corner. Within the 40 -acre tract, wells are sequentially numbered in the order they are inventoried. The final letter refers to the base line and meridian. In California, there are three base lines and meridians; Humboldt (H), Mount Diablo (M), and San Bernardino (S). All wells in the study area are referenced to the Mount Diablo base line and meridian. Well numbers consist of 15 characters and follow the format 003S007E13A001. In this report, well numbers are abbreviated and written $3 \mathrm{~S} / 7 \mathrm{E}-13 \mathrm{~A} 1$. The following diagram shows how the number for well 3S/7E-13A1 is derived.

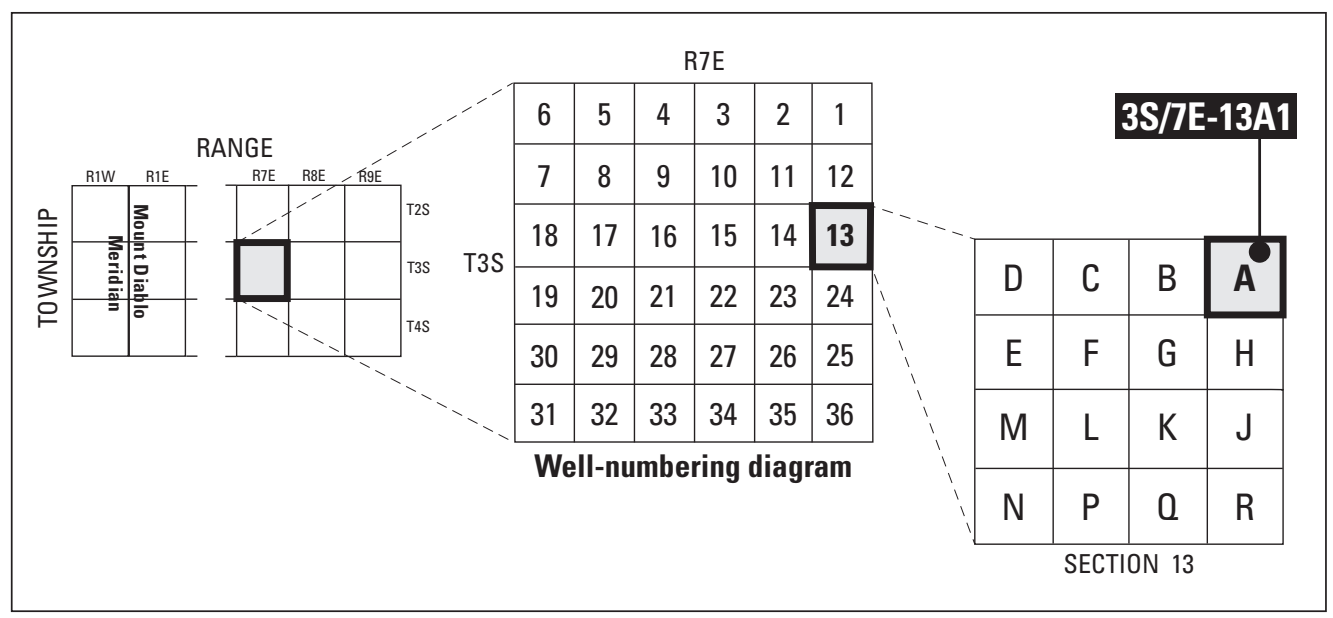




\title{
Hydrologic Model of the Modesto Region, California, 1960-2004
}

\author{
By Steven P. Phillips, Diane L. Rewis, and Jonathan A. Traum
}

\section{Abstract}

Strategies for managing water supplies and groundwater quality in the Modesto region of the eastern San Joaquin Valley, California, are being formulated and evaluated by the Stanislaus and Tuolumne Rivers Groundwater Basin Association. Management issues and goals in the basin include an area in the lower part of the basin that requires drainage of the shallow water table to sustain agriculture, intra- and inter-basin migration of poor-quality groundwater, and efficient management of surface and groundwater supplies. To aid in the evaluation of water-management strategies, the U.S. Geological Survey and the Stanislaus and Tuolumne Rivers Groundwater Basin Association have developed a hydrologic model that simulates monthly groundwater and surface-water flow as governed by aquifer-system properties, annual and seasonal variations in climate, surface-water flow and availability, water use, and land use. The model was constructed by using the U.S. Geological Survey groundwatermodeling software MODFLOW-OWHM with the Farm Process.

Available measurements of groundwater pumped for municipal, irrigation, and drainage purposes are specified in the model, as are deliveries of surface water. Private irrigation pumping and recharge associated with agricultural land use were estimated by using the Farm Process in MODFLOWOWHM, which simulates landscape processes associated with irrigated agriculture and other land uses. The distribution of hydraulic conductivity in the aquifer system was constrained by using data from more than 3,500 drillers' logs. The model was calibrated to 4,061 measured groundwater levels in 109 wells and 2,739 mean monthly surface-water flows measured at 6 streamgages during 1960-2004 by using a semiautomated method of parameter estimation.

The model fit to groundwater levels was good, with an absolute mean residual of 0.8 feet; 74 percent of simulated heads were within 10 feet of those observed. The model fit to streamflow was biased low, but reasonable overall; the absolute mean residual of streamflow was 780 cubic feet per second, and 68 percent of simulated streamflows were within
500 cubic feet per second of observed. Hydrographs both of groundwater levels and streamflow indicated overall an acceptable fit to observed trends.

Simulated private agricultural pumpage ranged from about 780,000 to $1,380,000$ acre-feet per year and averaged about 1,000,000 acre-feet per year from 1960 to 2004.

Simulated deep percolation, or groundwater recharge from precipitation and irrigation, varied with climate and land use from about 1,100,000 to 1,700,000 acre-feet per year, averaging 1,360,000 acre-feet per year. Key limitations of the model with respect to estimating these large components of the water budget are the uncertainty associated with actual irrigation deliveries and irrigation efficiencies and the lack of metered data for private agricultural groundwater pumping. Different assumptions with respect to irrigation deliveries and efficiencies, and other model input, would result in different estimates of private agricultural groundwater use.

The simulated exchange between groundwater and surface water was a small percentage of streamflow, typically ranging within a loss or gain of about 2 cubic feet per second per mile. The simulated exchange compared reasonably with limited independent estimates available, but substantial uncertainty is associated with these estimates.

\section{Introduction}

Strategies for managing local water supplies and groundwater quality are being formulated and evaluated by the Stanislaus and Tuolumne Rivers Groundwater Basin Association (STRGBA), an organization dedicated to understanding, managing, and protecting groundwater resources in part of the eastern San Joaquin Valley, California. The STRGBA oversees a region of about 300 square miles $\left(\mathrm{mi}^{2}\right)$ in area bounded by the San Joaquin River, the foothills of the Sierra Nevada, and the Stanislaus and Tuolumne Rivers (fig. 1). The members of STRGBA, as of the writing of this report, are the cities of Modesto, Oakdale, and Riverbank; Modesto and Oakdale Irrigation Districts; and Stanislaus County. 


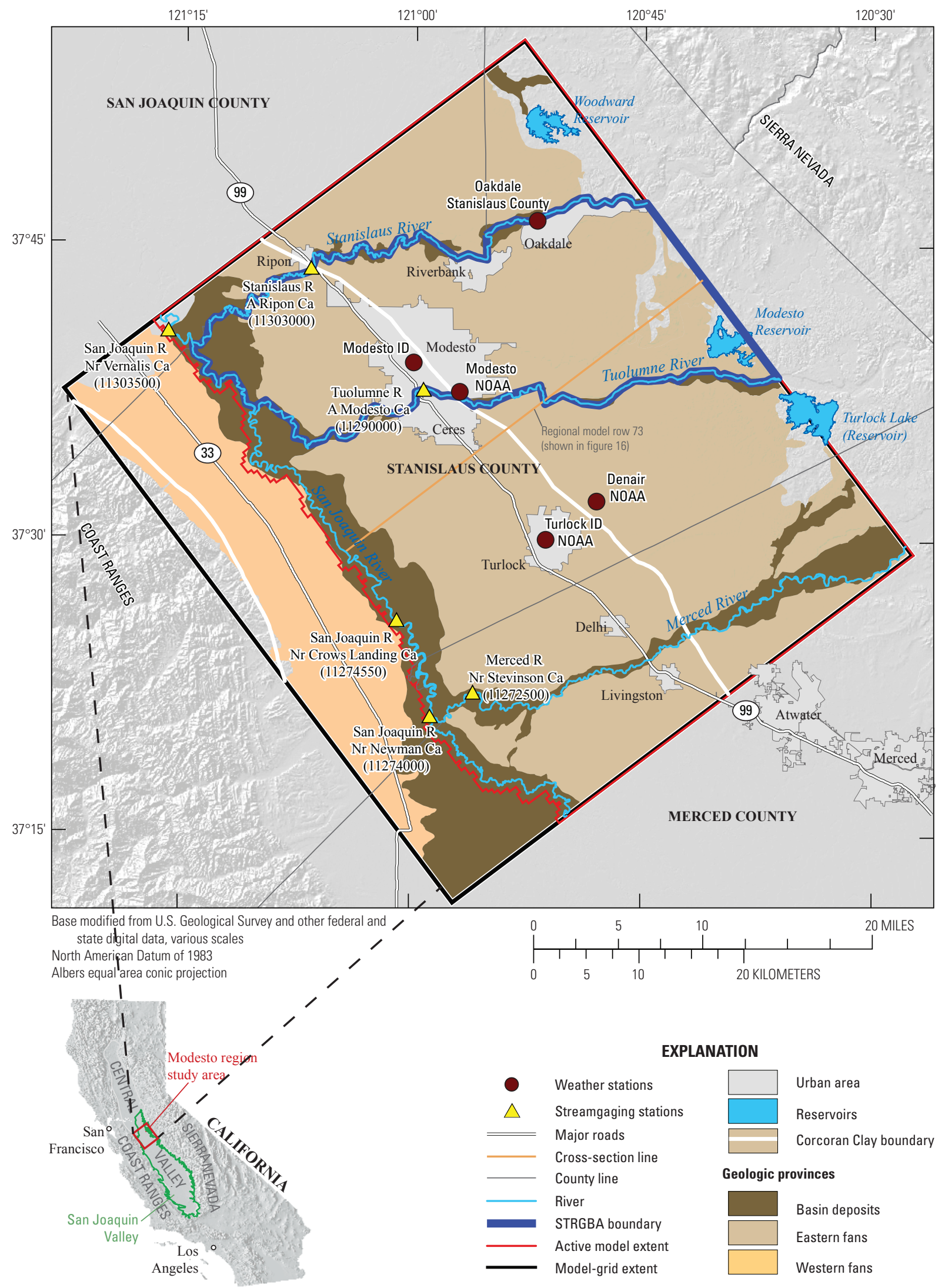

Figure 1. Location of the Stanislaus and Tuolumne Rivers Groundwater Basin Association (STRGBA) boundary in the study area, Modesto region, California. ID, Irrigation District. 
Water-management issues in the Stanislaus and Tuolumne Rivers Groundwater Basin include ongoing artificial drainage of shallow groundwater to maintain agriculture in lower parts of the basin and intra- and inter-basin migration of poorquality groundwater; a key goal is the efficient management of surface and groundwater supplies to meet current and future demands as well as possible. To aid in the evaluation of water-management strategies, the U.S. Geological Survey (USGS) and STRGBA worked cooperatively to understand the groundwater basin better and to develop a tool to help evaluate water-management options.

\section{Introduction to Development of Hydrologic Model}

A transient hydrologic model was developed as part of this study to simulate hydrologic conditions during 1960-2004 by calendar year (water years are used in this report where noted). This model, which simulates the area that spans from south of the Merced River to north of the Stanislaus River (fig. 1), is called the MERSTAN model. The key hydrologic processes in the region are simulated by the MERSTAN model, including groundwater and surfacewater flow, the interaction between these two systems, water use (groundwater pumping, surface-water deliveries, and so on), and landscape processes primarily associated with irrigated agriculture. Model input data, related analyses and assumptions, calibration data and methods, and model limitations are documented and discussed in this report.

\section{Purpose and Scope}

In the first phase of this USGS-STRGBA cooperative investigation, the USGS (1) defined the hydrogeologic framework of the basin by using existing data and information, and (2) collected and analyzed new hydrogeologic data to refine the conceptual model of the aquifer system. Results from the first phase were published in Burow and others (2004).

The purpose of this report is to document the results of the second phase of investigation: the development of the MERSTAN model, which was designed to help evaluate the effectiveness of current, and potential future, watermanagement activities. Such evaluations are not documented in this report.

\section{Description of Study Area}

The San Joaquin Valley is more than 250 miles (mi) long, 25 to $55 \mathrm{mi}$ wide, and occupies the southern two-thirds of the Central Valley of California (fig. 1). The valley floor is underlain by a structural trough filled with marine and continental sediments up to 6 mi thick (Gronberg and others, 1998). The Sierra Nevada rise east of the valley to a peak altitude of over 14,000 feet (ft); the Coast Ranges, having moderate altitude, form the western edge of the valley. The San Joaquin River drains the northern part of the San Joaquin Valley through San Francisco Bay; the southern part of the valley is a hydrologically closed basin.

The study area, which is the same as the model area (active portion) for this study, is a region surrounding the city of Modesto (also referred to as the Modesto region), covering about 1,000 $\mathrm{mi}^{2}$ in the northeastern San Joaquin Valley (fig. 1). The study area is bounded on the west by the San Joaquin River, on the north near the Stanislaus River, on the south near the Merced River, and on the east within the foothills of the Sierra Nevada.

\section{Topography and Climate}

The land surface in the study area slopes downward to the west from the foothills of the Sierra Nevada to the San Joaquin River; gradients range from less than 5 feet per mile (ft/mi) in downslope areas to more than $25 \mathrm{ft} / \mathrm{mi}$ in places near the foothills and next to streams and rivers (fig. 1). The climate is semi-arid, characterized by hot summers and mild winters; the rainfall averaged 12.4 inches (in.) annually from 1931 to 1997, falling mostly from late fall through early spring (National Oceanic and Atmospheric Administration, 2005).

\section{Land Use}

Agriculture is the primary land use, covering about 65 percent of the study area. The primary crops are almonds, walnuts, peaches, grapes, grain, corn, pasture, and alfalfa. The cities of Modesto, Turlock, and a number of smaller urban areas covered about 6 percent of the regional study area in 1995-96. The remaining area was predominantly natural vegetation near the foothills and in riparian areas (California Department of Water Resources, 2001a, 2001b).

\section{Water Use}

Agricultural irrigation supplied by surface water and groundwater accounted for about 94 percent of the total water use in the region during the year 2000, a normal climatic year (Burow and others, 2004). Surface-water supplies originate primarily from a series of reservoirs in the foothills of the Sierra Nevada. These supplies are managed by irrigation districts and delivered to agricultural users through hundreds of miles of pipelines and lined and unlined canals. 
Most irrigation districts and many private agricultural users also pump groundwater for irrigation; in addition, some districts pump groundwater to lower the water table in areas where it has risen too close to the land surface to support agriculture without active management- this practice is referred to as "drainage" in this report. Private agricultural groundwater use was not measured in the study area, but was estimated in a water-budget analysis (Burow and others, 2004) to be about 32 percent of total agricultural water use in water year 2000 (October 1, 1999, through September 30, 2000). The potential error in this estimate is high; reduction of this source of error was addressed in this study through direct simulation of agricultural processes.

Urban water demand is met by surface-water and groundwater supplies. Before 1995, the city of Modesto, the largest urban center in the study area, used groundwater exclusively for public supply. A surface-water treatment plant was completed by the Modesto Irrigation District in 1994, which provided about one-half of Modesto's municipal and industrial water supplies during the remainder of the study period. About 72 percent of the total urban water requirement, for all urban areas, was met by groundwater in water year 2000 (Burow and others, 2004).

Based on information from local drillers' logs, about 60 percent of wells in the study area were for domestic use; followed by 27 percent for irrigation; 4 percent for public supply; and 7 percent for test, stock, industrial, and other uses (Burow and others, 2004). Well depths ranged from $15 \mathrm{ft}$ to more than $1,200 \mathrm{ft}$ below land surface; the median depth was $194 \mathrm{ft}$. The median depths below land surface to the midpoints of perforated intervals in domestic, irrigation, and municipal wells were 154, 207, and $223 \mathrm{ft}$, respectively. Fewer wells were present during 1960-2004 in the northeastern part of the study area (near the northeastern boundary, toward the foothills) and along the San Joaquin River compared with the rest of the study area. The deepest wells generally were in the eastern part of the study area, and the shallowest wells were in the western part and along the rivers. Additional clusters of deep wells were in the urban areas (Burow and others, 2004).

Rural domestic groundwater use was unknown, but was assumed to be small compared to that for irrigation of crops and urban use.

\section{Previous Work}

In addition to the hydrologic characterization work by Burow and others (2004), previous work includes the development of a steady-state model of the same area as the current model (Phillips and others, 2007) in support of two smaller-scale modeling efforts by the USGS National Water Quality Assessment (NAWQA) Program (Domagalski and others, 2008; Burow and others, 2008). The steady-state model, funded by the USGS NAWQA Program, served as the basis for development of the current model. It represents hydrologic conditions during water year 2000 and incorporates the sediment-texture distribution and water budget developed by Burow and others (2004).

\section{Geohydrology}

\section{Geologic Setting}

The geologic setting of the region is discussed extensively by Burow and others (2004); their work is summarized briefly here. The Central Valley is a northwesttrending structural trough between the Sierra Nevada and the Coast Ranges (fig. 1; Bartow, 1991). The Sierra Nevada forms the eastern side of the valley, comprises primarily pre-Tertiary granitic rocks, and is separated from the Central Valley by a foothill belt of marine and metavolcanic rocks. The Coast Ranges lie on the western side of the valley and are a complex assemblage of rocks, including marine and continental sediments of Cretaceous to Quaternary age (Gronberg and others, 1998).

The San Joaquin Valley generally can be divided into three physiographic regions (fig. 1): the western alluvial fans, the eastern alluvial fans, and basin deposits (Burow and others, 2004). Alluvial-fan deposits on both sides of the valley comprise coarse-grained and fine-grained sediments heavily influenced, particularly on the east side, by fluvial processes. The sediments in the eastern alluvial-fan region, which are dominant in the study area, generally are more permeable than sediments in the western alluvial fan region because of their granitic source (compared to an oceanic source in the west) and the high relief and corresponding high-energy erosion of the Sierra Nevada. The basin deposits in the study area are a combination of coarse-grained channel deposits and finegrained deposits from flood events.

Consolidated rocks and deposits exposed along the margin of the valley floor include Tertiary and Quaternary continental deposits (fig. 2), Cretaceous and Tertiary marine sedimentary rocks, and the pre-Tertiary Sierra Nevada basement complex (Piper and others, 1939; Davis and others, 1959). The basement complex generally is thousands of feet deep in the study area, far below the deepest wells. The Mehrten Formation, the youngest of the Tertiary rocks, is made up of volcanic rocks of mafic composition. Unconsolidated deposits in the study area generally comprise gravel, sand, silt, and clay derived primarily from granitic sources, and most are contained within the PliocenePleistocene Laguna (not mapped at the surface in study area), Turlock Lake, Riverbank, and Modesto Formations. These are interspersed with minor amounts of Holocene dune, stream-channel, and flood-basin deposits (Davis and Hall, 1959; Arkley, 1962). The Turlock Lake, Riverbank, and Modesto Formations form a sequence of overlapping terrace and alluvial fan systems (Marchand and Allwardt, 1981), indicating cycles of alluviation, soil formation, and channel incision that were influenced by climatic fluctuations and the resultant glacial stages in the Sierra Nevada (Bartow, 1991). 


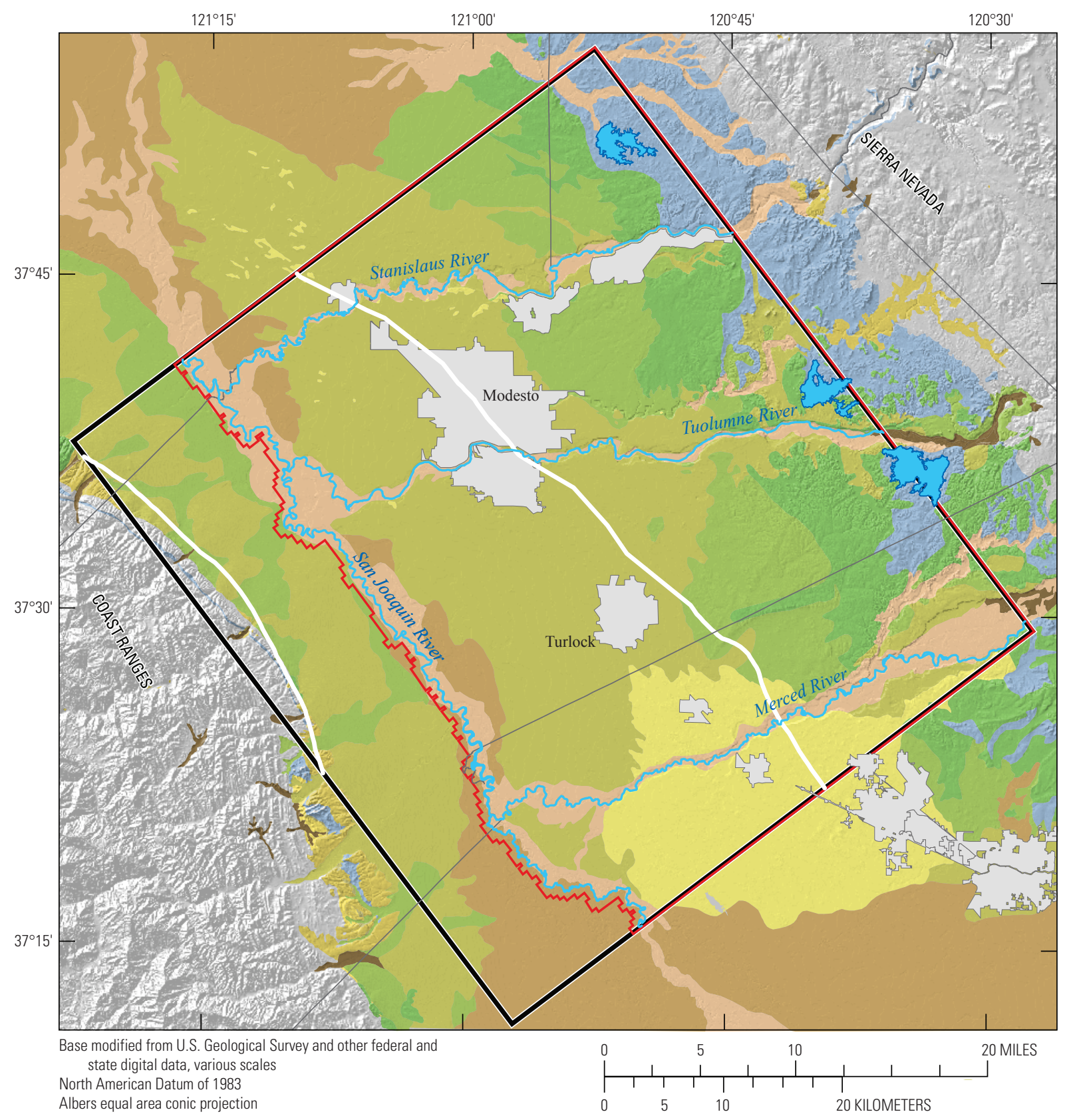

EXPLANATION

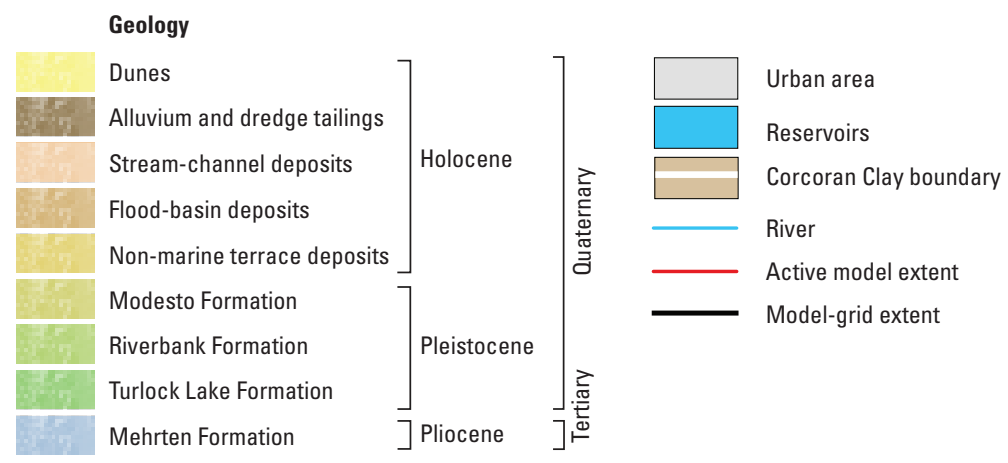

Figure 2. Selected surficial geologic units in the Modesto region, California. Modified from Burow and others, 2004. 
The Corcoran Clay, a lacustrine deposit and Member of the Tulare Formation (Croft, 1972) is a key hydrogeologic feature that limits vertical groundwater flow and confines groundwater flow in large parts of the San Joaquin Valley. The Corcoran Clay has been equated to the E-clay (Page, 1986) and the lacustrine clay in the Turlock Lake Formation in the study area (Marchand and Allwardt, 1981). Page (1986) used results of previous work and a limited number of well logs and geophysical logs to map the areal extent of this regional confining unit. Additional lithologic data from well logs were used recently to modify the mapped extent of this prominent unit in the regional study area (Burow and others, 2004). The eastern extent of the Corcoran Clay roughly parallels the San Joaquin River valley axis (fig. 2). In the study area, the top of the Corcoran Clay is between about 85 and $260 \mathrm{ft}$ below land surface, and the unit has a maximum thickness of about $190 \mathrm{ft}$.

The Mehrten Formation is a key part of the aquifer system tapped by wells in the eastern part of the study area (fig. 2) and marks a change in lithology and texture in the overlying sediments from primarily unconsolidated coarsegrained sediments of arkosic composition to the primarily consolidated sediments of volcanic-derived mafic materials that compose the formation. The Mehrten Formation outcrops in the eastern part of the regional study area and lies at least $400 \mathrm{ft}$ below land surface beneath Modesto (Burow and others, 2004).

\section{Sediment Texture}

The analysis of sediment texture is discussed in detail in Burow and others (2004) and is summarized here. The sediment-texture distribution from that report was used to define the distribution of hydraulic conductivity for the steadystate model by Phillips and others (2007) and the MERSTAN model.

With the exception of the Corcoran Clay, the subsurface distribution of the geologic formations discussed previously is not well understood and, therefore, was not used directly in the development of the MERSTAN model. To better understand the spatial variability of sedimentary materials in the subsurface, an approach based on sediment texture information from a subset of about 10,000 available drillers' logs was used to develop a three-dimensional model of sediment texture; this model was used to define the distribution of hydraulic properties in the study area. This approach was similar to that developed by Laudon and Belitz (1991) and Phillips and Belitz (1991) and subsequently adapted for other studies (for example, Phillips and others, 2007; Faunt, 2009; Faunt and others, 2010).
To facilitate this texture-based approach, an earlier phase of this study focused on the development of a database to organize information about well construction and subsurface lithology in the study area (Burow and others, 2004). About 10,000 drillers' logs were examined. Because sediment descriptions on drillers' logs can be ambiguous and widely variable in the interpretation of lithology, a rating scheme, modified from Laudon and Belitz (1991), was developed to select a subset of about 3,500 logs for analysis. In addition to lithologic information, the database contains well-construction information, which was used for other purposes in this study.

A geostatistical approach was used to generate a threedimensional, heterogeneous sediment-texture distribution for the study area by using the primary texture of sediments from the database (Burow and others, 2004). Lithologic descriptions in the database were expressed as a percentage of coarse-grained sediment for 1-meter (about $3.3 \mathrm{ft}$ ) depth intervals. These percentages were then interpolated by using three-dimensional kriging, with no lateral anisotropy, over a 400 -meter (about $0.25 \mathrm{mi}$ ) grid in the horizontal dimension for successive 10-meter (about $33 \mathrm{ft}$ ) thick intervals in the vertical dimension. A detailed description of kriging parameters is provided by Burow and others (2004). The resulting estimated texture distributions for selected depths below the land surface are shown in figure 3 . The estimated texture distributions were well constrained (high density of drillers' logs) by sedimenttexture data to a depth of about $160 \mathrm{ft}$, reasonably constrained to $330 \mathrm{ft}$, and poorly constrained below $330 \mathrm{ft}$. For the deeper parts of the aquifer system, for which no data were available, the texture value estimated for the lowest layer containing data was used in all underlying model cells. These cell-bycell texture values were used to generate the distribution of hydraulic conductivity values, as described in the "Hydraulic Conductivity" section of this report.

Key depositional patterns in the sediment-texture distribution are evident in figure 3, particularly at the shallower depths. For example, at a depth of $82 \mathrm{ft}$ (fig. $3 B$ ), the texture distribution shows coarse-grained materials generally aligned with the river channels, and fine-grained materials generally between the channels. This makes geologic sense with respect to the depositional environment, because rivers are capable of transporting and depositing coarse-grained materials over long distances within their channels. Also apparent in figure $3 B$ is a potential ancestral channel of the Tuolumne River, south of its current position. This analysis of data from thousands of drillers' logs enabled the inclusion of these types of geologic features in the MERSTAN model. 

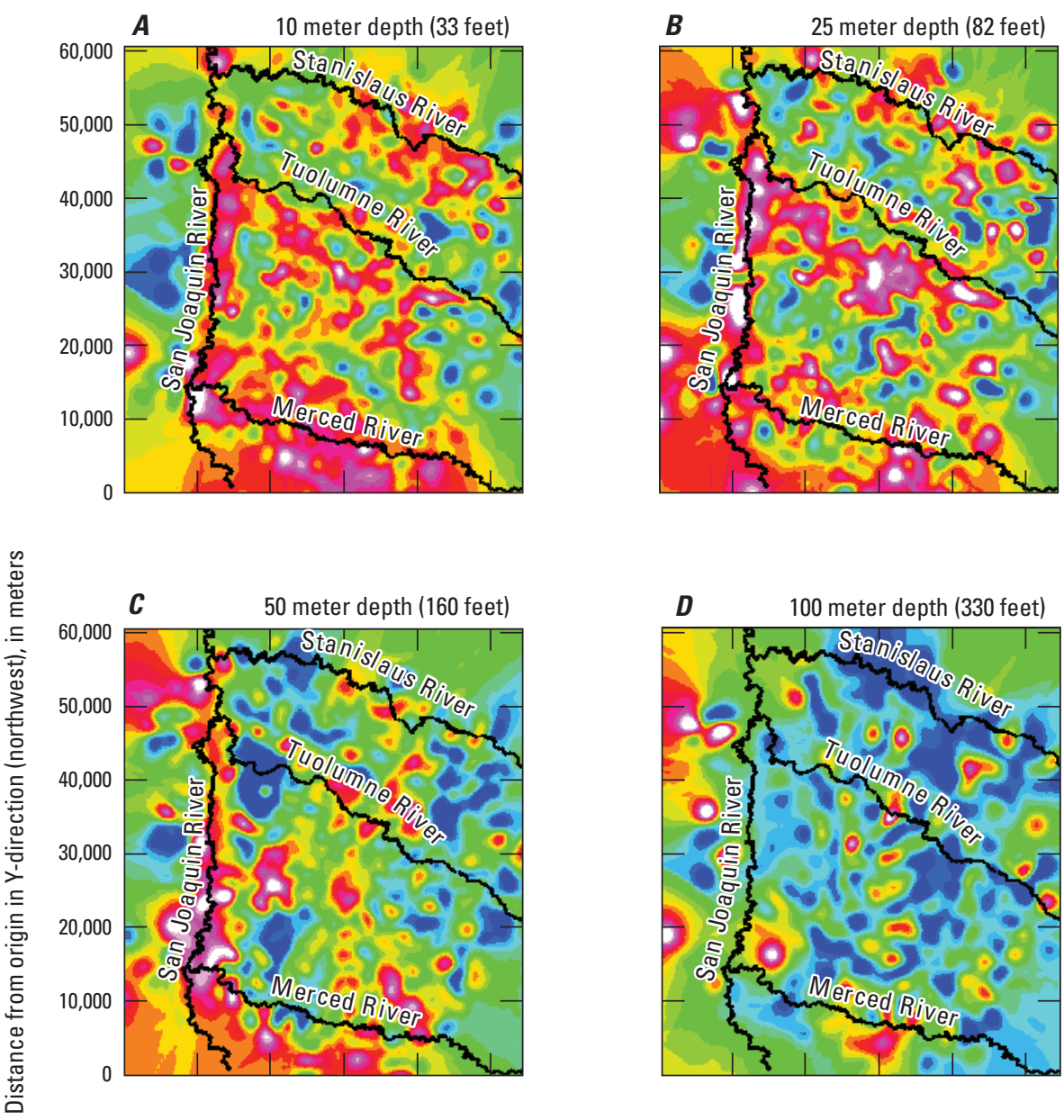

EXPLANATION

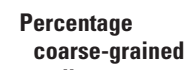

sediments
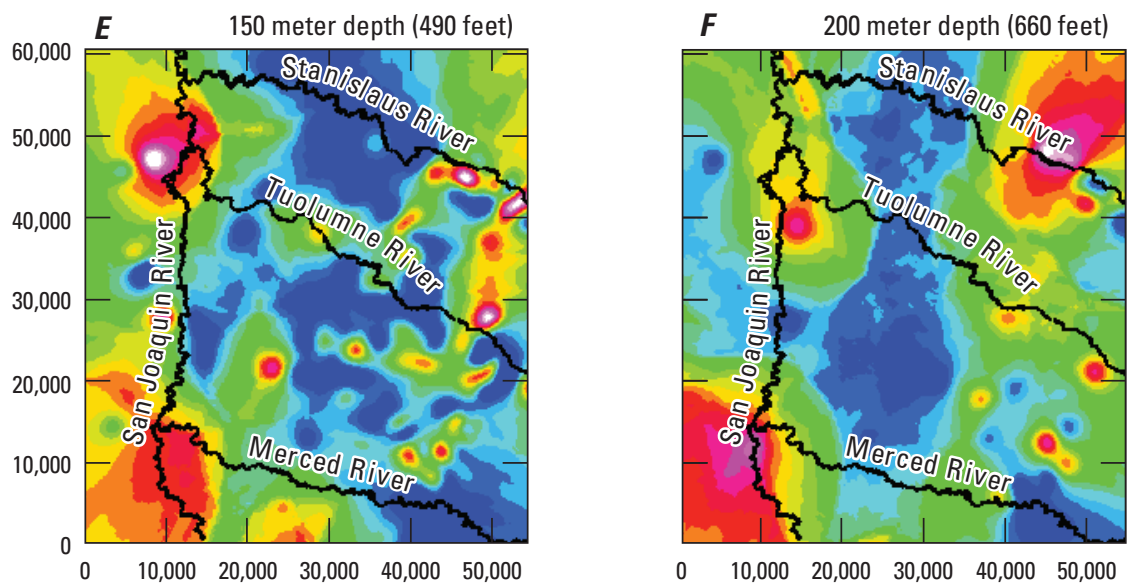

Distance from origin in X-direction (northeast), in meters

Figure 3. Two-dimensional slices through a three-dimensional model of the percentage of coarse-grained sediments for the Modesto region, California. Modified from Burow and others (2004). 
Hydrologic Model of the Modesto Region, California, 1960-2004

\section{Hydrologic Setting}

The aquifer system in the study area is composed of Tertiary and Quaternary alluvial deposits derived from the surrounding mountains. The basin-fill comprises coalescing alluvial fans, which tend to be coarser-grained near the mountains and finer-grained toward the center of the basin. On the basis of the sediment-texture model, fluvial deposition is an important depositional process east of the San Joaquin River, resulting predominantly in coarse-grained sediments associated with stream channels and fine-grained sediments between these channels. The Corcoran Clay Member of the Tulare Formation is a lacustrine deposit that separates the aquifer system in the basin-fill deposits into an upper, unconfined to semi-confined aquifer and a lower, confined aquifer in much of the study area (Burow and others, 2004).

Under natural conditions, recharge was distributed spatially and in the upper alluvial fans, where streams enter the basin; groundwater discharged primarily to the San Joaquin River and surrounding marshlands. Groundwater pumping for irrigation and public supply, combined with delivery of surface water for irrigation, has greatly altered the distribution of recharge and discharge (Burow and others, 2004). Groundwater flow has become more complex because increased surficial recharge and groundwater withdrawal have increased vertical flow in the system; water on a lateral flow path can be repeatedly removed by pumping and reapplied at the surface.

\section{Groundwater Recharge and Discharge}

Sources of recharge in the study area include agricultural-return flow (defined here as deep percolation of irrigation water not consumptively used), deep percolation of precipitation, reservoir leakage, and seepage from streams. Groundwater discharges to pumping wells, rivers, transpiration, and evaporation. Information is available for some of these processes in the study area. Results from a study conducted by the Modesto Irrigation District, which manages the Modesto Reservoir, indicated a leakage rate of about 24,000 acre-feet per year (acre-ft/yr; Modesto Irrigation District, 1999). The estimated leakage rate for Woodward Reservoir, which is about the same size as Modesto Reservoir, was 22,000 acre-ft/yr (Davids Engineering, Inc., 2012).

Discharge to pumping wells was measured for urban wells and wells owned or used by irrigation districts, generally. Measured monthly pumping by well was provided by the city of Modesto and other relatively large urban areas for the later years of the study period. Monthly total measured pumpage by city was available from the California Department of Water Resources (1968, 1975, 1983, 1994); for Modesto, these data were available from 1960 to 1990 and for Ceres and Turlock, from 1980 to 1990. A similar series of monthly pumpage data for individual wells or groups of wells was available for smaller communities serviced by the city of Modesto, including Waterman, Hickman, Del Rio, Grayson, and Salida. For the communities without available pumpage data during the earlier years of the study period, the average per capita monthly usage was calculated by using the available data, and monthly pumpage was extrapolated back to 1960 on the basis of population.

The resulting measured and estimated urban pumpage from 1960 to 2004 is shown in figure 4. Total urban pumping showed a nearly linear increase between 1960 and the late 1980 s, from less than 20,000 acre-ft/yr to about 90,000 acre-ft/yr, followed by a leveling and then decreasing during the 1987-92 drought (fig. 4A). Post-drought pumpage remained relatively low, at about 80,000 acre-ft/yr, compared to the late 1980s. This is at least partly due to reduced pumpage by the city of Modesto, which began in 1995, when surface-water deliveries from the Modesto Irrigation District were initiated. The average monthly distribution of urban groundwater use (fig. $4 B$ ) showed the low was in February, representing primarily indoor water use, followed by a steady climb to a peak in July and August, coincident with increased irrigation demand.

Pumpage data were not available for domestic wells. Although domestic wells were common in the study area, much of the water from these small-capacity wells was returned to the aquifer system by way of septic systems; therefore, the net use was assumed to be a negligible percentage of total groundwater pumpage.

Pumping by Modesto and Turlock Irrigation Districts (MID and TID, respectively) for drainage purposes was measured during 1960-2004 (fig. 5A). The measured drainage pumpage for TID was greater than that for MID, owing to larger acreage in the southwestern part of TID, where the water table was shallow, compared to that in MID. Total drainage pumpage decreased over time, from an average of about 150,000 acre-ft/yr during the 1960 s to about 50,000 acre-ft/yr during 2002-04. There was a marked decline during the 1987-92 drought (fig. 5A). Average monthly drainage pumpage from 1960 to 2004 varied from less than 2,500 acre-feet (acre-ft) to greater than 12,500 acre-ft, consistent with the primary spring and summer irrigation season (fig. 5B).

Data for private agricultural pumpage were not available for the study area. This component of groundwater use was estimated for an earlier phase of this study as the residual water demand from a water-budget analysis of water-year 2000 (October 1, 1999, through September 30, 2000; Burow and others, 2004). For this study, private agricultural pumpage was estimated by using the Farm Process in MODFLOW (Schmid and Hanson, 2009; Hanson and others, 2014), which was designed specifically to help estimate this large component of groundwater discharge; it also was used to estimate deep percolation of irrigation and precipitation, major components of total recharge in the study area. 

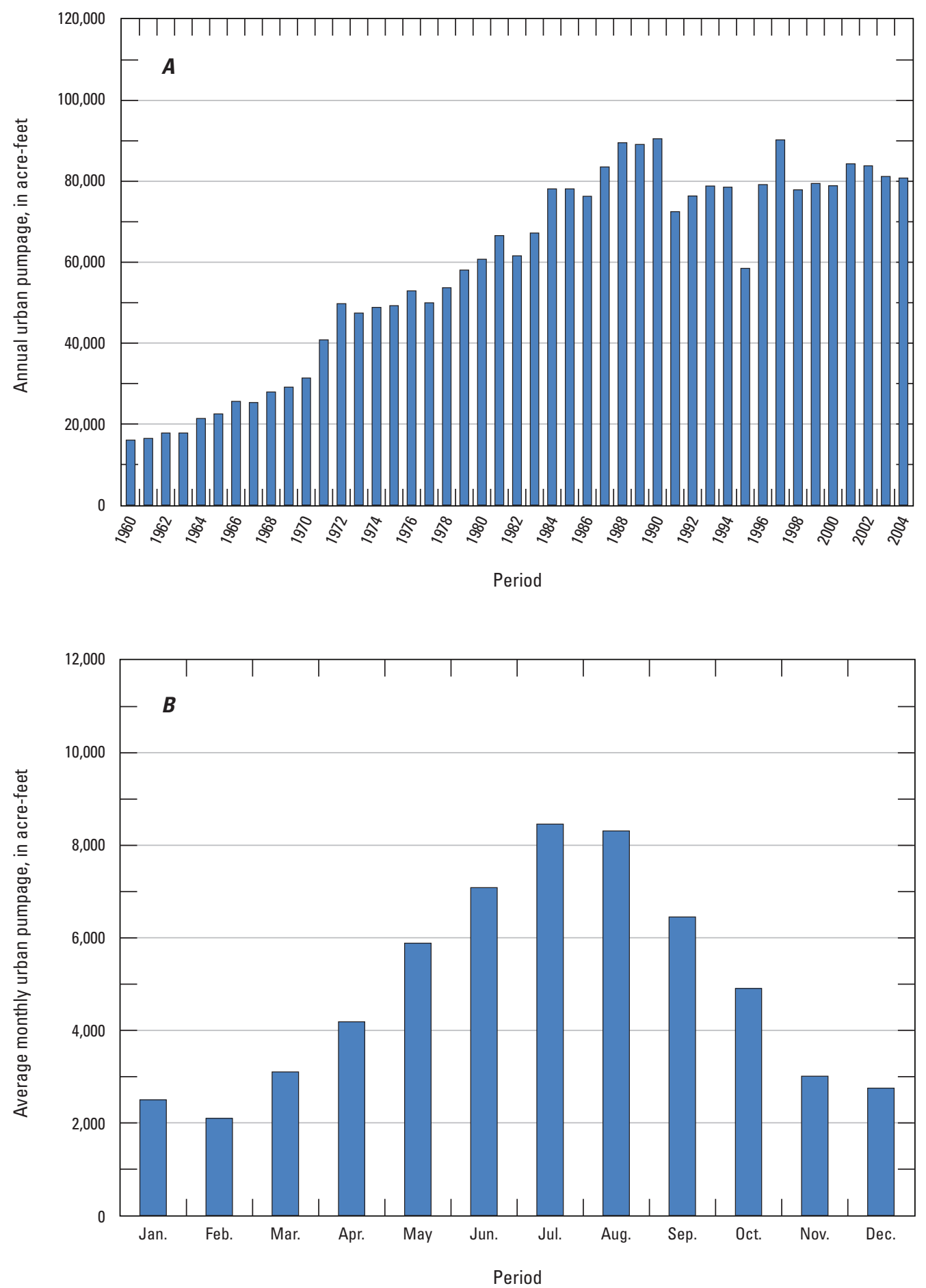

Figure 4. Measured and estimated urban groundwater pumpage from 1960 to 2004, Modesto region, California: $A$, annual total and $B$, average monthly. 

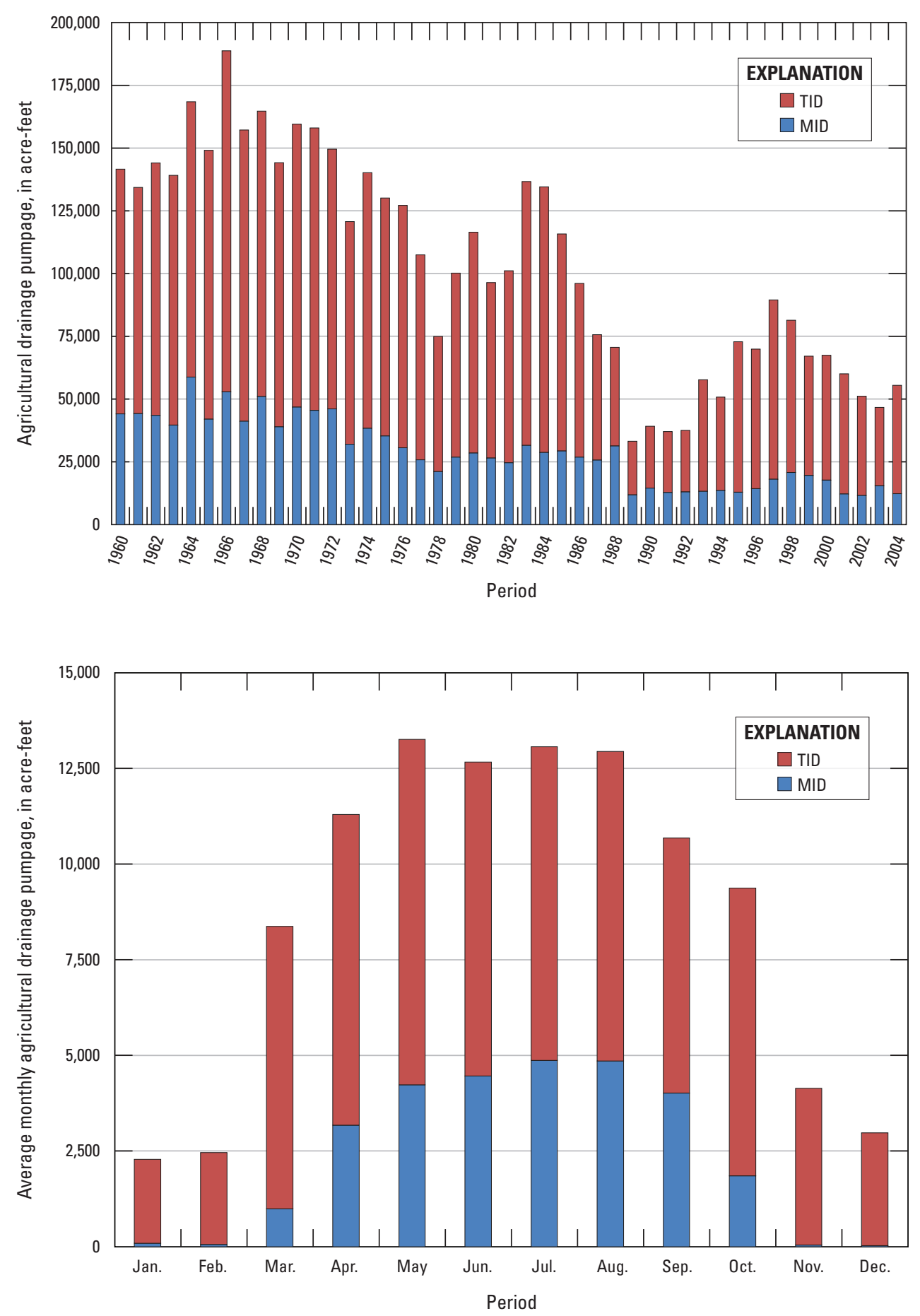

Figure 5. Agricultural drainage pumpage from 1960 to 2004 for the Modesto (MID) and Turlock (TID) Irrigation Districts, Modesto region, California: $A$, annual total and $B$, average monthly. 


\section{Description of Aquifer System}

Groundwater is in the unconfined to semi-confined aquifer overlying and east of the Corcoran Clay, within the Corcoran Clay, and in the underlying confined aquifer. The thickness of the unconfined to semi-confined aquifer overlying the Corcoran Clay ranges from about 85 to $260 \mathrm{ft}$ in the study area. East of the Corcoran Clay, this aquifer comprises primarily unconsolidated alluvial sediments, but includes the upper part of the more consolidated Mehrten Formation. Some irrigation and public-supply wells were completed in coarsegrained units in the upper Mehrten. The confined aquifer comprises alluvial sediments and upper Mehrten Formation sediments from beneath the Corcoran Clay to the deepest fresh water, well below the depths encountered in this study. The contribution of groundwater from the consolidated rocks beneath the primary aquifers was assumed to be negligible and was not considered.

\section{Groundwater Levels and Movement}

Groundwater levels are shallow (often within 10 feet of the land surface) in much of the western part of the study area. Within the STRGBA boundary (fig. 1), these areas are generally southwest of Modesto and Turlock, roughly bounded by the San Joaquin, Stanislaus, and Merced Rivers; the area of shallow groundwater in the Turlock region is indicated by the shallow (15 ft in depth) wells used to map shallow water levels in figure 6 (yellow squares). Water is pumped from shallow wells in these areas to lower the water table so crop roots are not damaged; this water is added to irrigation canals and delivered to downstream areas for irrigation. Depth to the water table increased eastward, particularly south of the Tuolumne River, where depths can exceed $130 \mathrm{ft}$ within a large cone of depression (fig. 6). In the area underlain by a shallow water table, groundwater also can discharge in the form of uptake by plants (transpiration) and evaporation from the soil; these processes would help mitigate water-table rise near the land surface.

Groundwater levels in the Modesto region during 1960-2004 generally remained stable or decreased (see the "Model Calibration and Sensitivity" section of this report). Those in the area underlain by a shallow water table generally were stable, varying seasonally and with climatic extremes, such as during drought conditions in 1976-77 and 1987-92. Groundwater levels in other areas ranged from stable to long-term declines. The greatest declines were in the Eastside Water District (northeast of the city of Turlock, fig. 1), which does not have surface-water rights; these declines commonly exceeded $50 \mathrm{ft}$ during the study period.
Data from multi-depth USGS monitoring wells in the Modesto urban area (see the "Model Calibration and Sensitivity" section of this report) showed that vertical hydraulic gradients from the water table (about $30 \mathrm{ft}$ below land surface) to the deeper production zones of most municipal wells (about 130-330 ft below land surface) were strongly downward and greater during spring and summer (gradient of about 0.2-0.3) than during fall and winter (gradient of less than 0.1 ). Seasonal water-level fluctuations were about $20 \mathrm{ft}$ in the deeper wells and generally less than $3 \mathrm{ft}$ in the USGS water-table wells. Monthly groundwater levels measured in a network of shallow (15 ft in depth) wells by Turlock Irrigation District (see fig. 6 for locations of these $15-\mathrm{ft}$ wells) showed maximum seasonal fluctuations exceeding $5 \mathrm{ft}$ and typical fluctuations of about $3 \mathrm{ft}$.

Under natural conditions, groundwater was primarily recharged spatially from precipitation and at the upper parts of the alluvial fans where the major streams enter the valley (fig. 1). Groundwater flow followed the southwest slope of the basement complex and the dip of the overlying sedimentary deposits toward the southwest in the direction of the valley trough, along the San Joaquin River. Upward hydraulic gradients and artesian conditions near the San Joaquin River indicated discharge to the river and surrounding marshlands (Davis and others, 1959).

Groundwater development in the basin changed the patterns of groundwater flow. Post-development groundwater withdrawals for agricultural irrigation and deep percolation of that irrigation water greatly exceeded natural discharge and recharge, respectively, causing an increase in vertical flow in the system (Page and Balding, 1973; Londquist, 1981). In spring 2000, groundwater near the water table generally flowed toward the southwest (fig. 6), as it did prior to development. However, groundwater moving along a lateral flow path can be extracted by wells and reapplied at the surface multiple times before reaching the valley trough, at which point it can flow beneath the San Joaquin River toward pumping centers on the west side of the valley rather than discharge to the river (Burow and others, 2004). In spring 2000, a groundwater-flow divide was centrally located south of the Tuolumne River and oriented approximately perpendicular to the river. East of the divide, groundwater flowed eastward toward irrigation wells east of Turlock, an agricultural area with no surface-water supplies; west of the divide, groundwater generally flowed southwestward toward the valley trough (fig. 6). 


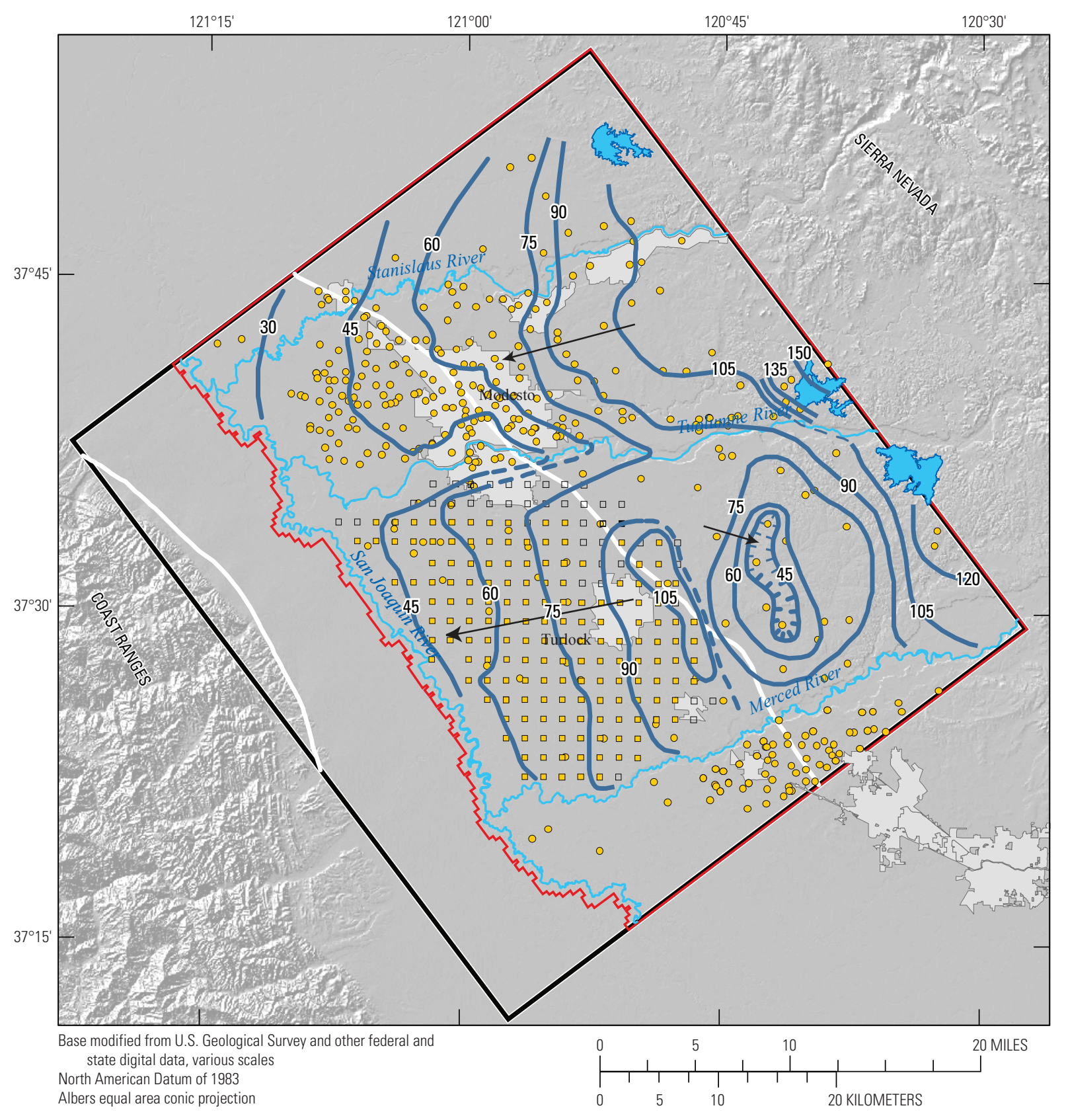

EXPLANATION

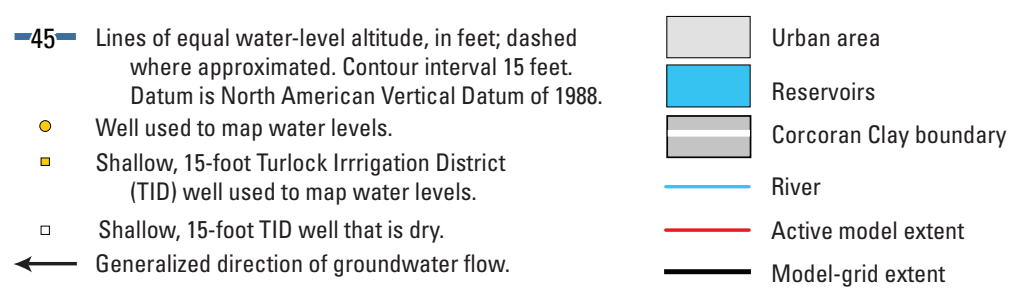

Figure 6. Contours of measured water-level altitude in the unconfined to semi-confined aquifer, spring 2000, Modesto region, California. Modified from Phillips and others, 2007. 


\section{Surface Water}

The San Joaquin River is the central drainage for the northern San Joaquin Valley and is the western boundary of the study area. Streamflow is expressed in terms of mean monthly streamflow in this report, because that is the equivalent simulated by the MERSTAN model. Streamflow in the San Joaquin River during 1960-2004 ranged from less than 100 cubic feet per second (cfs) near where the river enters the study area at the southern boundary to greater than 40,000 cfs at the gage "San Joaquin R Nr Vernalis, Ca," downstream from the confluence with the Stanislaus River, near the northwestern boundary of the study area (fig. 1). Low streamflow, usually in the 100-1,000 cfs range for the San Joaquin River, is typical during the dry months of summer and early fall. Streamflow generally is high during the wet winter months and frequently exceeds $10,000 \mathrm{cfs}$.

The Stanislaus, Tuolumne, and Merced Rivers drain the Sierra Nevada and are key tributaries to the San Joaquin River. The Tuolumne is the largest tributary and has typical average monthly low streamflow in the 100-400 cfs range; high average monthly streamflow often exceeds $1,000 \mathrm{cfs}$ and occasionally exceeds 10,000 cfs. Low streamflow on the Merced River generally is below $100 \mathrm{cfs}$, and high streamflow is about 5,000 cfs. Low average monthly streamflow on the Stanislaus is typically at least $100 \mathrm{cfs}$; high streamflow generally is less than $10,000 \mathrm{cfs}$.

All rivers in the study area have been modified by impoundments and diversions and are altered notably from their natural state; multiple upstream reservoirs are used for storage, irrigation and power generation. Oakdale Irrigation District (fig. 7) receives surface water from New Melones Reservoir, on the Stanislaus River, which has a capacity of 2,400,000 acre-ft. Modesto and Turlock Irrigation Districts receive surface water from Don Pedro Reservoir, on the Tuolumne River, which has a capacity of 2,030,000 acre-ft. Reservoirs in the study area are much smaller and are used for temporary storage of diverted streamflow prior to delivery. From north to south, these are Woodward Reservoir, north of the Stanislaus River, and Modesto Reservoir and Turlock Lake, north and south, respectively, of the Tuolumne River (fig. 1).

An extensive network of mostly lined canals is used to deliver water from the local reservoirs for irrigation and urban use. Sources of this irrigation water include surface water diverted from the tributaries and groundwater pumped by irrigation districts for supply and for drainage. Water in these canals in excess of demand is discharged to the rivers. Because of data limitations, these discharges to rivers were not simulated in the MERSTAN model.

\section{Interaction of Groundwater and Surface Water}

The magnitude and direction of exchange between groundwater and surface water is largely unknown, but some estimates were available. A previous study of a 19-mile reach of the San Joaquin River between the streamgage near Newman (at the confluence with the Merced River) and the town of Patterson (fig. 1) showed predominantly gaining conditions (groundwater inflow to the river) during a droughtaffected 11-month period in 1988-89; the average estimated groundwater inflow was $2 \mathrm{cfs} / \mathrm{mi}$ (Phillips and others, 1991). A later study (Zamora and others, 2013) estimated groundwater inflow to a 59-mile reach of the San Joaquin River between a small tributary south of the study area and the gage near Vernalis (fig. 1) during 2006-08, a period that ranged climatically from wet to dry conditions, but was not as dry as during the previous study. The estimated average groundwater inflow from this study was about $1 \mathrm{cfs} / \mathrm{mi}$.

Analysis of temperature and water-level measurements taken from March 2004 through October 2005 in and below the streambed of the Merced River about three miles west of Hwy 99 indicated predominantly gaining conditions and an average groundwater inflow of about $1 \mathrm{cfs} / \mathrm{mi}$ (Zamora, 2006).

\section{Irrigated Agriculture and Other Landscape Data}

The Farm Process (version FMP3, Hanson and others, 2014) was used in the MERSTAN model to simulate landscape processes associated with irrigated agriculture, undeveloped areas (natural vegetation), and unpaved urban areas. Input data for the Farm Process are described in this section. The MERSTAN model was divided into 63 waterbalance subregions (WBSs; fig. 7), or groups of model cells, for which the Farm Process was used to simulate key processes on the landscape. The dominant land use in the study area was irrigated agriculture; accordingly, the WBSs in large irrigation districts were defined primarily on the basis of irrigation water delivery accounting units, known locally as ditch-tender areas, for which monthly delivery volumes were available for this study. Thus, Modesto, Oakdale, and Turlock Irrigation Districts were each represented by multiple waterbalance subregions representing ditch-tender areas (fig. 7). 


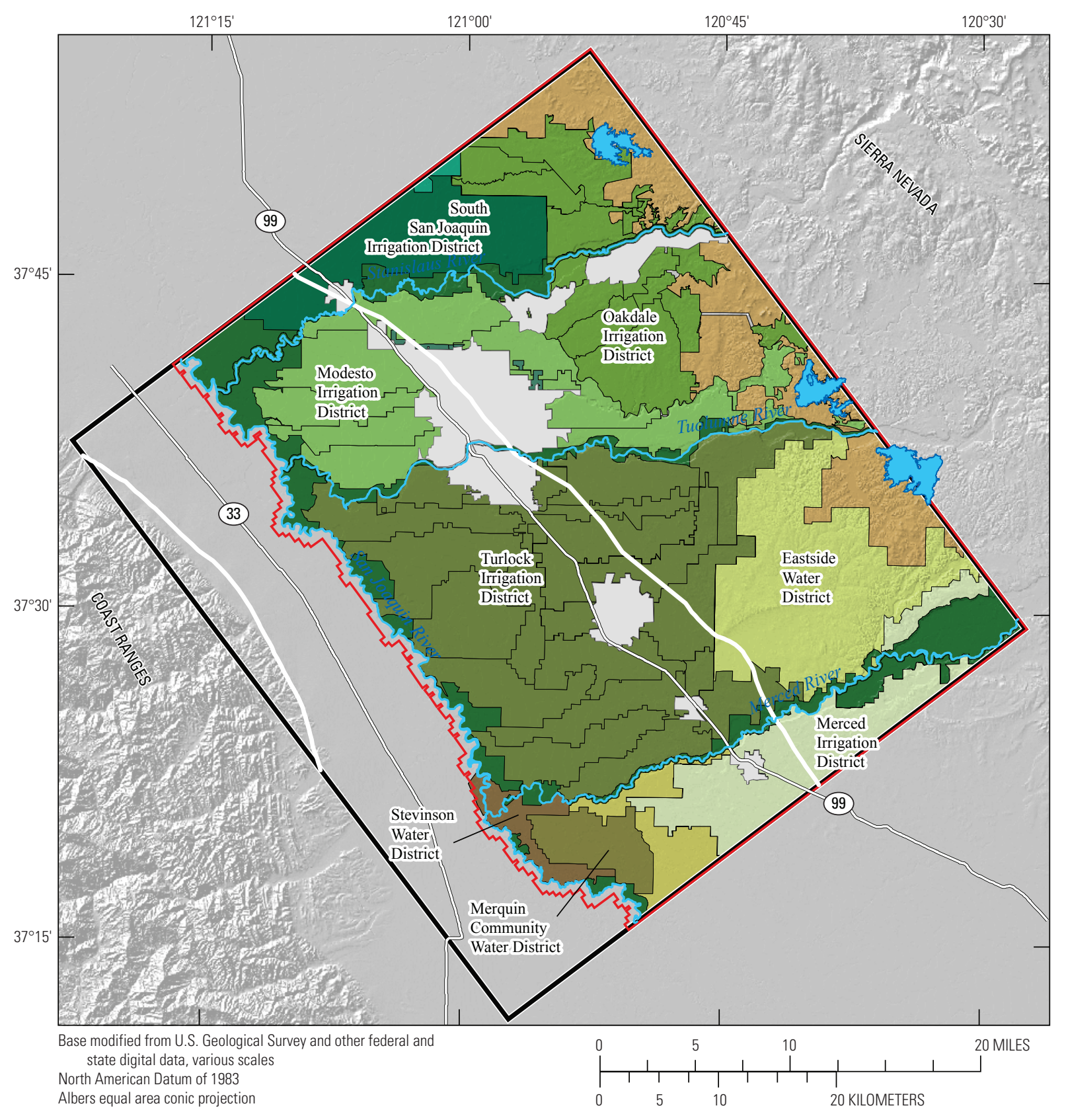

EXPLANATION

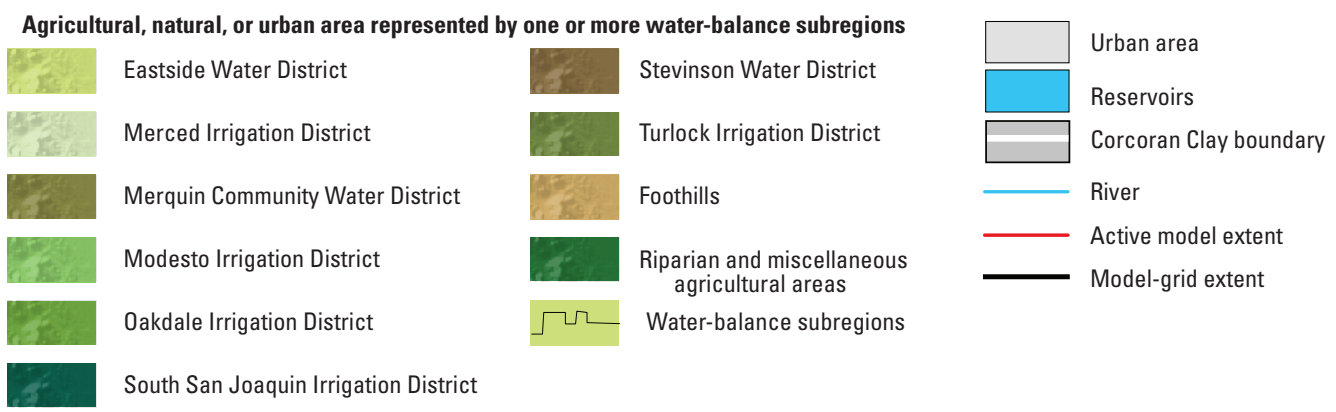

Figure 7. Agricultural, natural, and urban areas represented in the MERSTAN model by one or more water-balance subregions, Modesto region, California. Modesto, Oakdale, and Turlock Irrigation Districts were divided into multiple water-balance subregions. 


\section{Land Use}

Land use is a key driver for the Farm Process, defining the changing agricultural and urban footprints and trends in crop type. The land use in the study area from 1960 to 2004 was defined by using high-quality but low-frequency (every 6-8 years) maps from the California Department of Water Resources for San Joaquin County (1988 and 1996), Merced County (1995 and 2002), and Stanislaus County (1996 and 2004; www.water.ca.gov/landwateruse/lusrvymain.cfm). Annual total crop acreages, by county, were obtained from the offices of the Agricultural Commissioner for San Joaquin County (http://www.sjgov.org/agcomm/annualrpts.aspx), Stanislaus County (http://www.stanag.org/crop-reports. shtm), and Merced County (http://ageconsearch.umn.edu/ bitstream/94291/2/MERCED\%201961-1966.pdf and http://www.co.merced.ca.us/Archive.aspx). The land-use maps, which covered the recent portion of the study period, were used in conjunction with annual trends indicated by the total crop acreages to develop annual maps for intervening and earlier years. Each annual land-use map was adjusted manually to match the acreage trend and location of each crop type between mapped years as well as possible.

There were many crop types grown in the study area, and it was impractical to include each individual crop. Some individual crop types, for example, corn and cotton, were included because of their importance or unique characteristics. Most crop types were represented as groups of crops that had similar growth and water consumption characteristics, as defined in the land-use maps from California Department of Water Resources mentioned previously. The crop and other land-use types used for this study are shown in table 1.

The resulting time-series of annual land-use maps showed substantial changes from 1960 (fig. 8) to 2004 (fig. 9) that were reflected in the annual crop acreages (fig. 10). Definitions of the land-use categories shown on the maps are included in table 1. Most notable was the large increase in deciduous trees, primarily almonds and walnuts, and corresponding decrease in pasture and natural vegetation. Urban areas grew, and increased corn acreage (primarily silage) was largely offset by decreasing alfalfa (figs. 8-10).
Table 1. Crop categories and types, and associated maximum root depths and lowest and highest irrigation efficiencies, specified in the MERSTAN model, Modesto region, California.

[Abbreviations: ID, identification; - , none; \%, percent; >, greater than]

\begin{tabular}{|c|c|c|c|c|}
\hline \multirow[t]{2}{*}{$\begin{array}{l}\text { Crop } \\
\text { ID }\end{array}$} & \multirow[t]{2}{*}{ Description } & \multirow[t]{2}{*}{$\begin{array}{l}\text { Maximum } \\
\text { root depth, } \\
\text { in feet }\end{array}$} & \multicolumn{2}{|c|}{$\begin{array}{c}\text { Irrigation } \\
\text { efficiency } \\
\text { (dimensionless) }\end{array}$} \\
\hline & & & Lowest & Highest \\
\hline-1 & Fallow & - & - & - \\
\hline 1 & $\begin{array}{l}\text { Grain (for example, wheat, } \\
\text { oats, rye) }\end{array}$ & 3.9 & 0.5 & 0.65 \\
\hline 2 & Rice & 5.2 & 0.5 & 0.65 \\
\hline 3 & $\begin{array}{l}\text { Field crops (for example, } \\
\text { beans, hay) }\end{array}$ & 4.9 & 0.5 & 0.65 \\
\hline 4 & Cotton & 9.2 & 0.5 & 0.65 \\
\hline 5 & Corn & 6.6 & 0.5 & 0.65 \\
\hline 6 & Pasture & 5.2 & 0.5 & 0.65 \\
\hline 7 & Alfalfa & 3.9 & 0.5 & 0.65 \\
\hline 8 & Turf & 3.3 & 0.5 & 0.65 \\
\hline 9 & $\begin{array}{l}\text { Truck crops (for example, } \\
\text { melons, squash, tomatoes, } \\
\text { onions) }\end{array}$ & 6.2 & 0.5 & 0.65 \\
\hline 10 & Artichoke & 3.3 & 0.5 & 0.65 \\
\hline 11 & Asparagus & 3.3 & 0.5 & 0.65 \\
\hline 12 & Christmas trees & 6.6 & 0.5 & 0.65 \\
\hline 13 & Strawberries & 2.6 & 0.5 & 0.65 \\
\hline 14 & Deciduous trees & 12.8 & 0.5 & 0.80 \\
\hline 15 & Citrus trees & 10.5 & 0.5 & 0.80 \\
\hline 16 & Vineyards & 6.6 & 0.7 & 0.80 \\
\hline 17 & $\begin{array}{l}\text { Abandoned orchards and } \\
\text { vineyards }\end{array}$ & 5.2 & 0.5 & 0.65 \\
\hline 18 & Natural vegetation and riparian & 10.8 & 0.5 & 0.65 \\
\hline 19 & Urban turf, $0-25 \%$ by area & 3.3 & 0.5 & 0.65 \\
\hline 20 & Urban turf, $26-50 \%$ by area & 3.3 & 0.5 & 0.65 \\
\hline 21 & Urban turf, $51-75 \%$ by area & 3.3 & 0.5 & 0.65 \\
\hline 22 & Urban turf, $>75 \%$ by area & 3.3 & 0.5 & 0.65 \\
\hline 23 & Urban, impervious & - & - & - \\
\hline
\end{tabular}




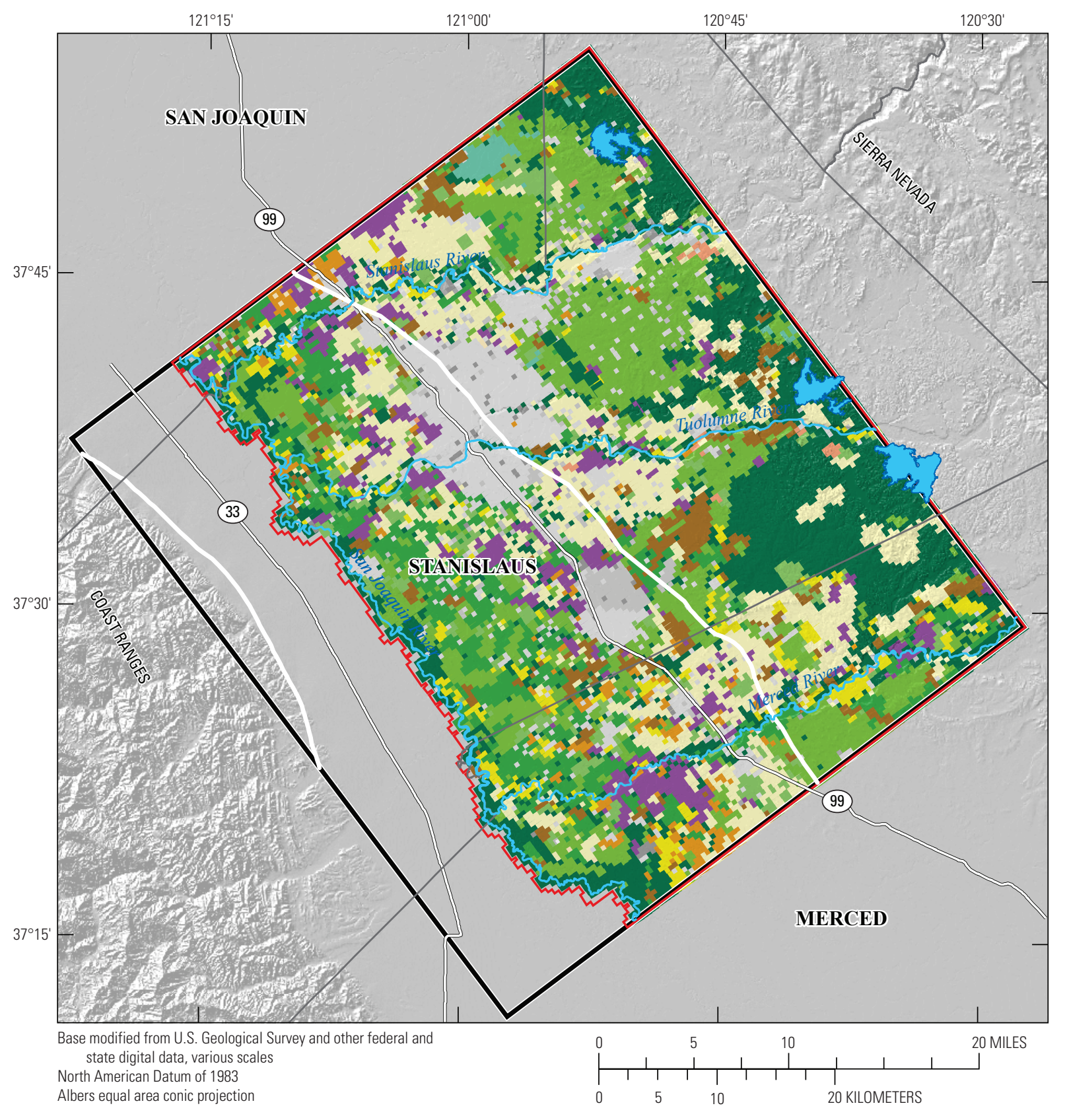

EXPLANATION

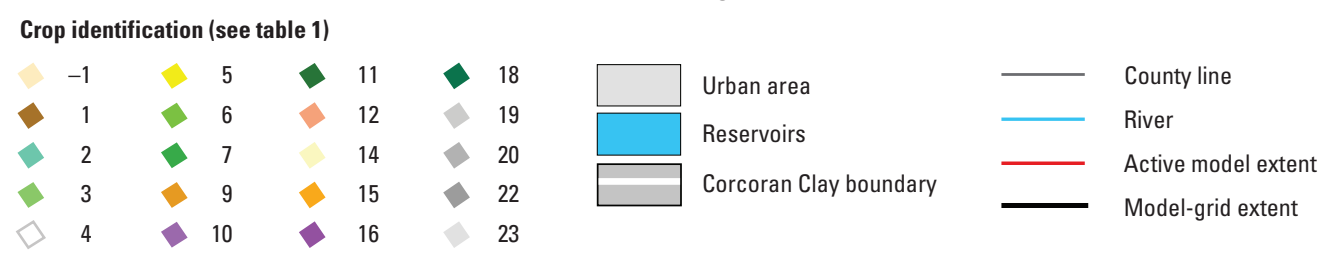

Figure 8. Estimated distribution of land use in 1960, Modesto region, California. The land-use definitions are shown in table 1. 


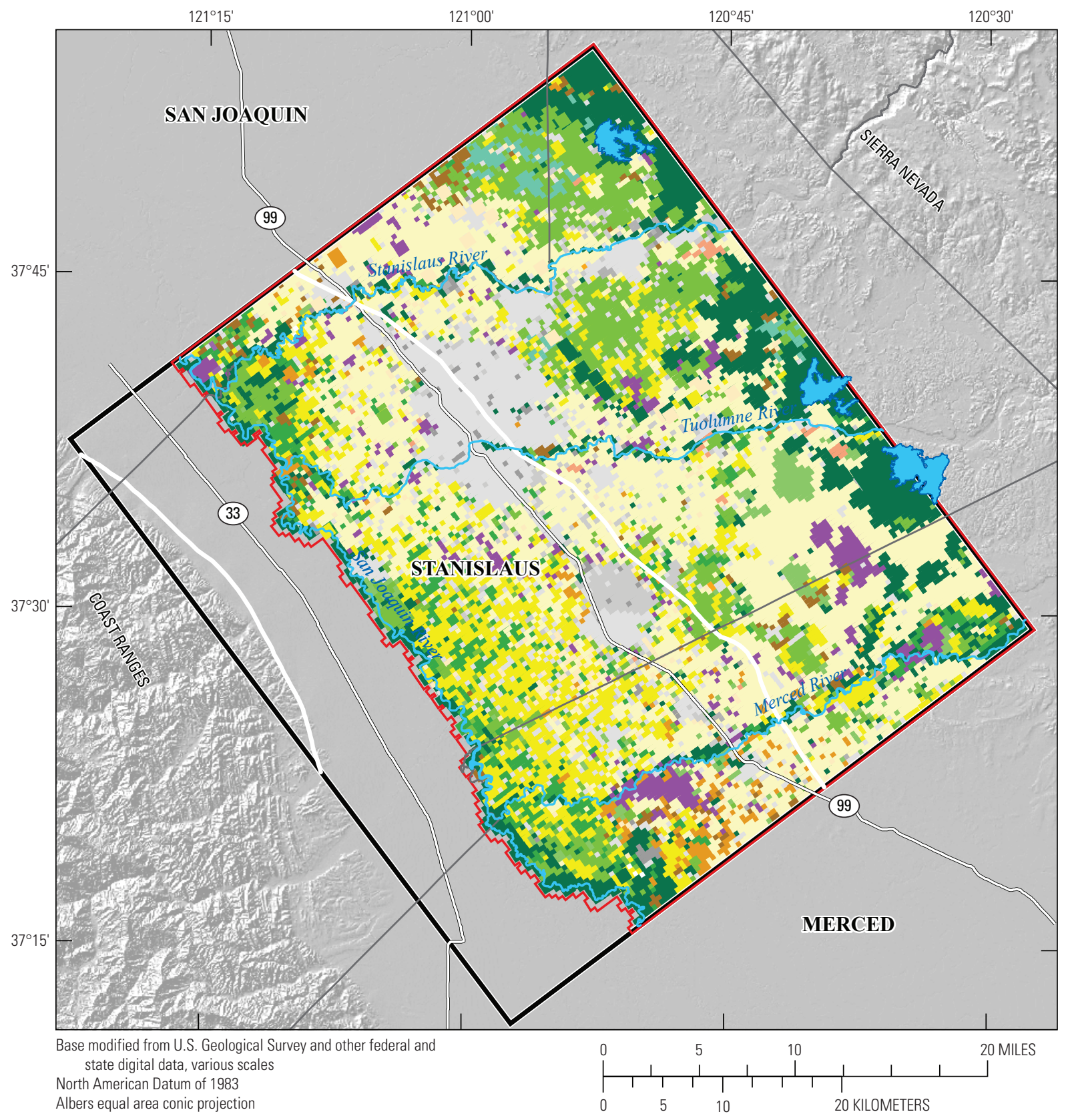

EXPLANATION

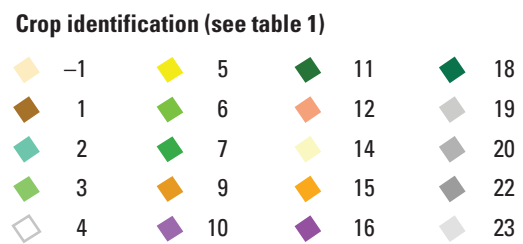
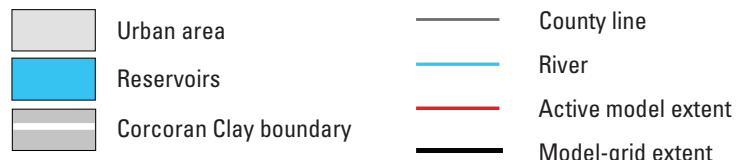

Figure 9. Composite circa-2004 land use in the Modesto region, California, based on 1996 (San Joaquin County), 2002 (Merced County), and 2004 (Stanislaus County) land-use data. The land-use definitions are shown in table 1. (Data source: California Department of Water Resources: http://www.water.ca.gov/landwateruse/lusrvymain.cfm). 


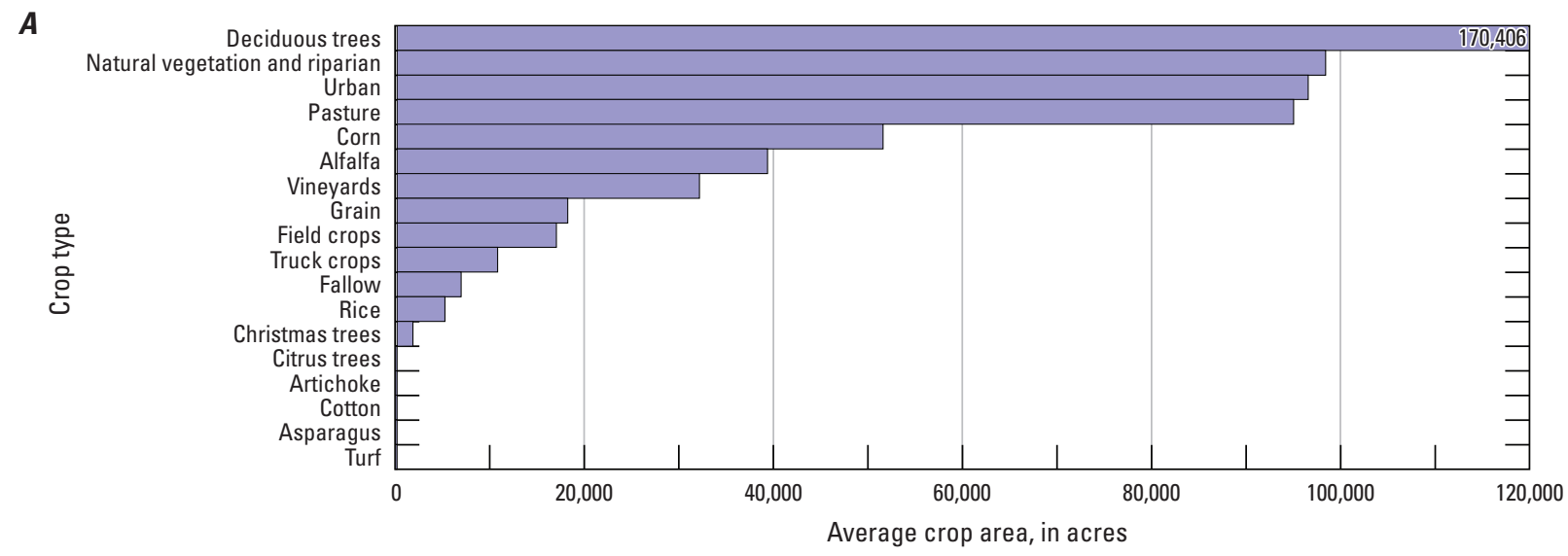

$\boldsymbol{B}$

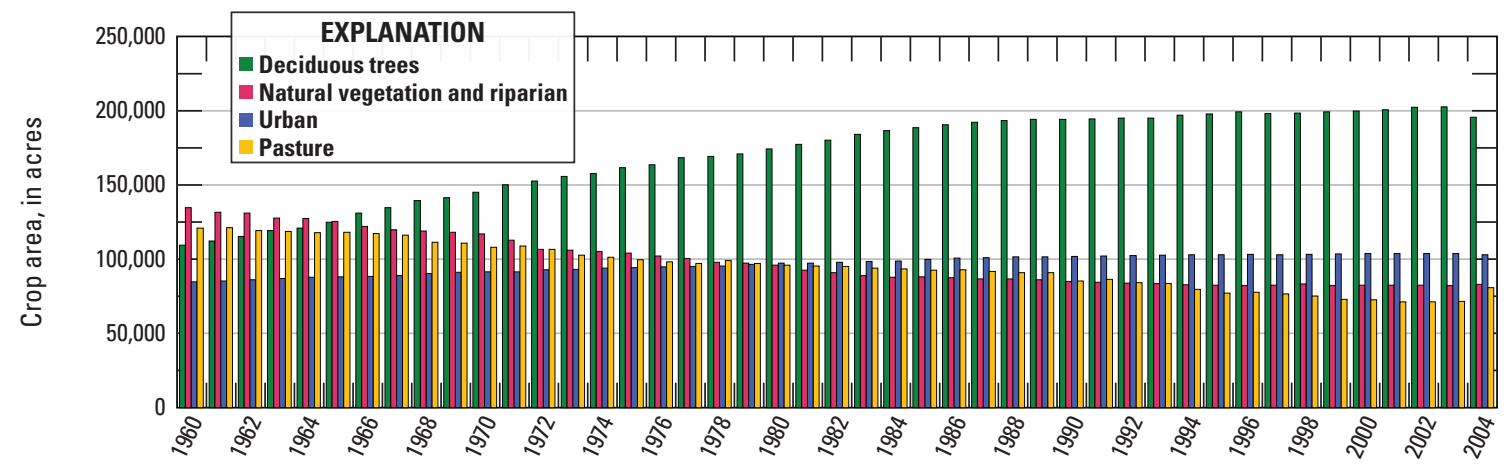

$\boldsymbol{C}$

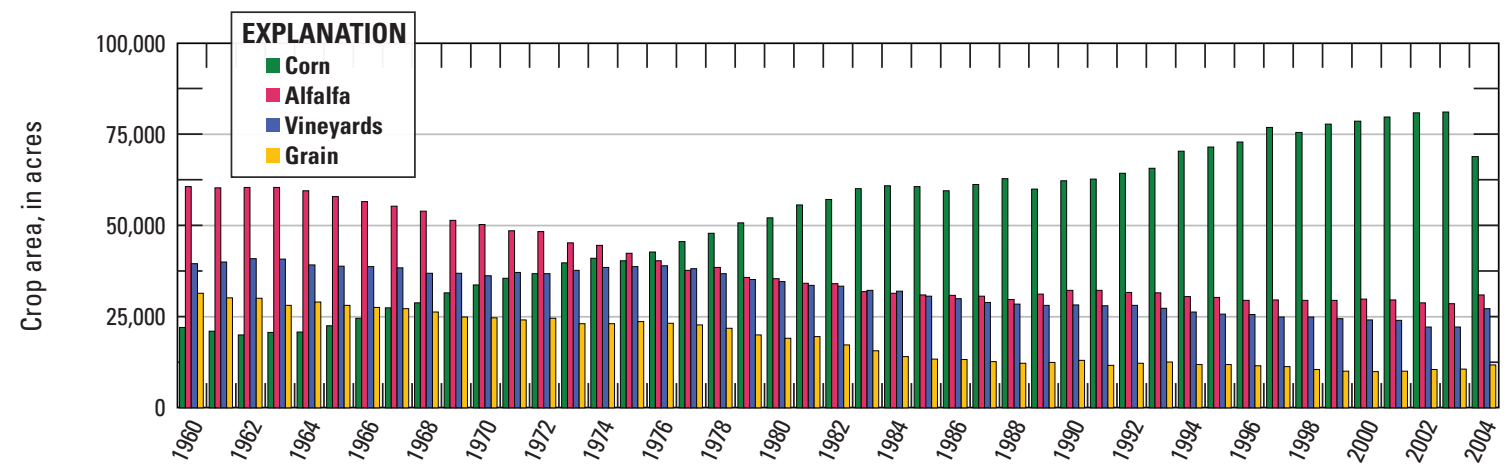

$\boldsymbol{D}$

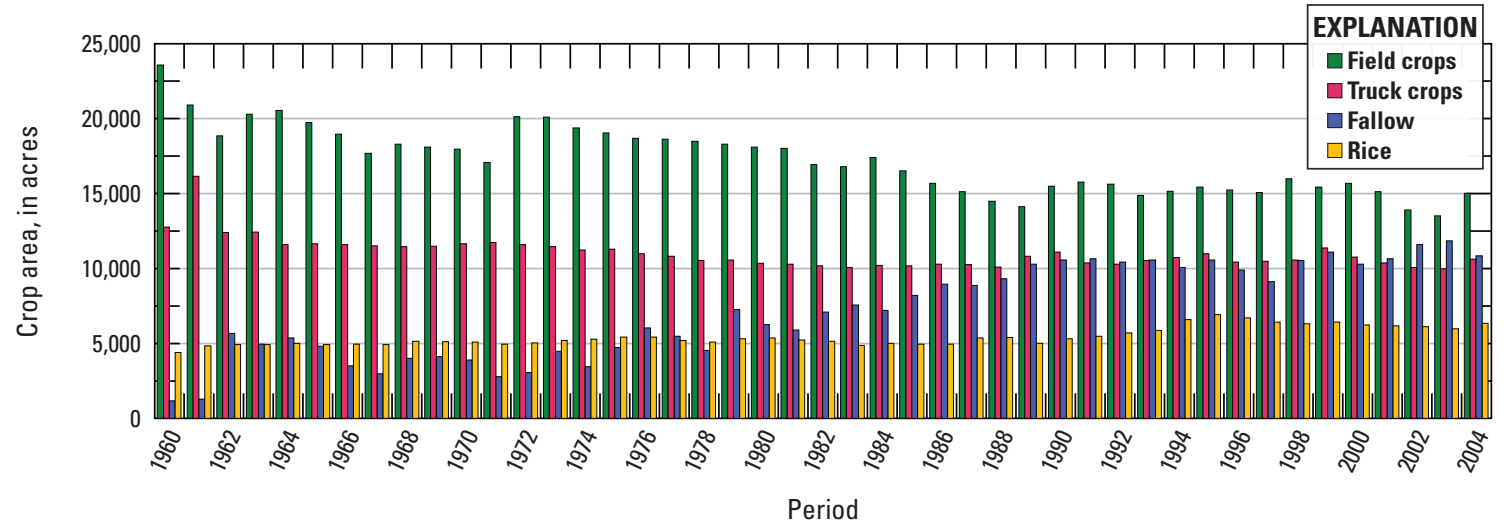

Figure 10. Land use in the Modesto region, California, 1960-2004: $A$, average acreage of crops and other land uses; $B$, time series of acreage for deciduous trees, natural vegetation and riparian, urban, and pasture; $C$, time series of acreage for corn, alfalfa, vineyards and grain; and $D$, time series of acreage for field crops, truck crops, fallow acreage, and rice. 


\section{Crop-Related Data}

Data requirements for the Farm Process include cropspecific information for each crop type listed in table 1. Five categories of crop-specific information used in the MERSTAN model are described in following sections.

\section{Depth of Root Zone}

The depth of the root zone for each crop was specified as a constant value representing the maximum root depth for that crop. Root depths used in the MERSTAN model ranged from $2.6 \mathrm{ft}$ for strawberries to $12.8 \mathrm{ft}$ for deciduous trees (table 1). It was assumed that nothing grew on fallowed land or impervious urban areas.

\section{Crop Coefficients}

Potential evapotranspiration was estimated in the Farm Process by multiplying the reference evapotranspiration, which was estimated spatially and is discussed in the Evapotranspiration section of this report, by a monthly crop coefficient. The crop coefficients are expressed as fractions, and represent the potential evapotranspiration of a given crop relative to a reference crop, a type of grass. The monthly crop coefficients used in the MERSTAN model, which were not varied annually, are shown in table 2.

\section{Transpiratory and Evaporative Fractions of Consumptive Use}

The transpiration and evaporation associated with consumptive use are partly a function of the growth stage, and related canopy cover, of each crop type. The greater the canopy cover, the greater the transpiration by plants and the lower the evaporation from soil. This relation is expressed as monthly fractions of the total evapotranspiration associated with transpiration $\left(\mathrm{F}_{\mathrm{tr}}\right)$ and evaporation of precipitation $\left(\mathrm{F}_{\mathrm{ep}}\right)$ and irrigation $\left(\mathrm{F}_{\mathrm{ei}}\right)$. Because precipitation falls uniformly at the scale of a plant, $F_{\text {tr }}$ plus $F_{\text {ep }}$ is equal to one. Irrigation in the study area generally is applied uniformly by flood, sprinkler, or border-strip methods; in those cases, $\mathrm{F}_{\mathrm{tr}}$ plus $\mathrm{F}_{\mathrm{ei}}$ is also equal to one, and $\mathrm{F}_{\mathrm{ei}}$ is equal to $\mathrm{F}_{\mathrm{ep}}$. For crops often associated with more direct irrigation methods, such as micro-sprinklers or drip systems, the $\mathrm{F}_{\mathrm{ei}}$ can be less than the $\mathrm{F}_{\mathrm{ep}}$. The values of the transpiratory and evaporative fractions of consumptive use specified in the MERSTAN model are shown in table 3.

\section{Irrigation Efficiency}

Irrigation efficiency is conceptually defined for the Farm Process as the fraction of irrigation water available for consumptive use by plants. The remaining fraction (one minus the irrigation efficiency) is available for deep percolation, or groundwater recharge. In the MERSTAN model, irrigation efficiency was not varied through time and was defined for each crop type by WBS. The range of irrigation efficiencies by crop type is shown in table 1; these are assumed values, because no estimates of irrigation efficiency for the region were available. The lowest value of 0.5 represents primarily flood and similar methods of irrigation, which were predominant in the study area. The highest value of 0.8 represents micro-sprinkler or drip systems used to irrigate trees and vineyards in Eastside Water District, which uses only groundwater, and where high-efficiency systems have been observed in the field.

\section{Soils}

Soil type is used in the Farm Process to define the depth of the? capillary fringe, which is used in the calculation of uptake of groundwater by plants. Four soil types were included in the MERSTAN model: sand, sandy loam, silt, and silty clay. These soil types were specified on the basis of STATSGO data (U.S. Department of Agriculture, Natural Resources Conservation Service, http://websoilsurvey.sc.egov. usda.gov/App/HomePage.htm, accessed in 2007); their distribution is shown in figure 11. The dominant soil type is sandy loam, which is in all but the southernmost part of the study area. The southernmost part of the study area and smaller areas along the Sierra foothills primarily have sandy soils. Soils in the floodplains of rivers and creeks in the study area are predominantly silty clay and silt (fig. 11).

\section{Climate}

Climatic conditions are a factor in defining water supply and demand on the landscape. Climate-related input to the Farm Process includes monthly precipitation and reference evapotranspiration, which is the evapotranspiration rate from a reference crop, a type of grass, given no shortage of water.

\section{Precipitation}

Monthly maps of precipitation in the study area from 1960 to 2004 were obtained from PRISM (http://www.prism. oregonstate.edu/, accessed in 2007). These maps were based on monthly models constrained by local climate stations; the maps prior to 1981 were constrained by fewer climate stations than those from 1981on (http://www.prism.oregonstate.edu/). Precipitation is generally in the form of rainfall and varies slightly within the study area, increasing with latitude and topography to the north and east. Average annual precipitation for the study period, based on the PRISM maps, ranged from about 6 to 25 inches per year (in./yr), averaging about 12 in. (fig. 12A). The associated average monthly precipitation peaked during January at about $2.4 \mathrm{in}$. and was less than 0.1 in. during the summer months (fig. 13). 


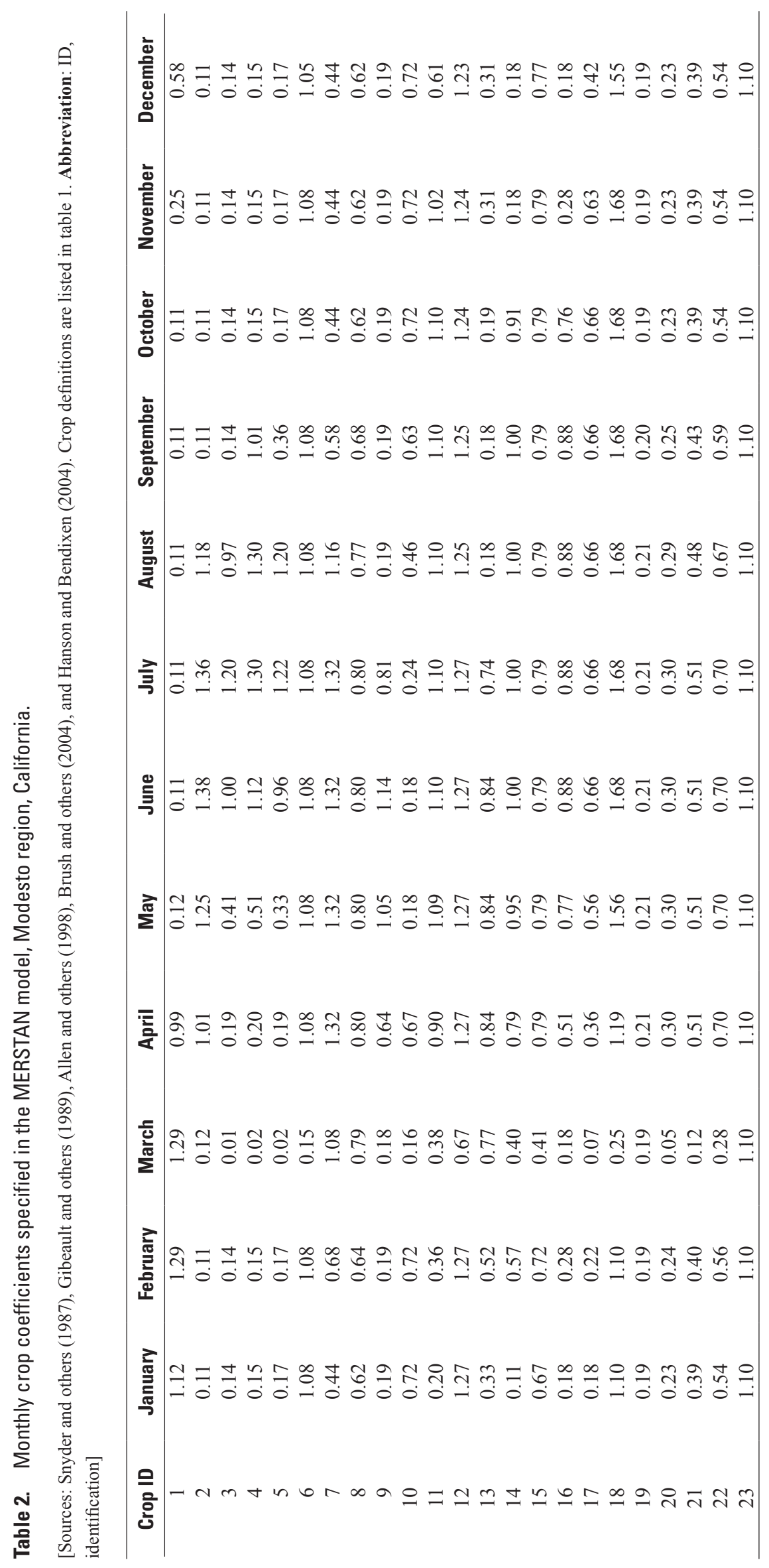


ш

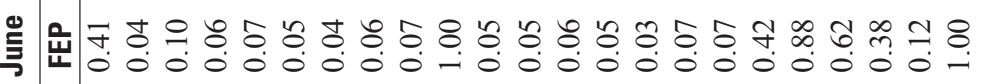

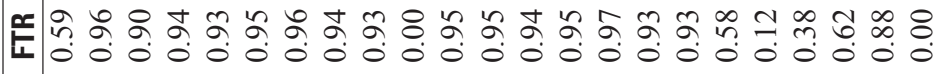

ш

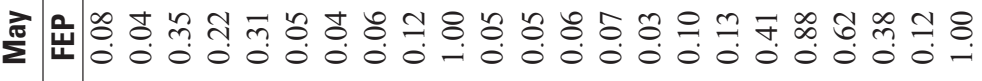

딴

Ш

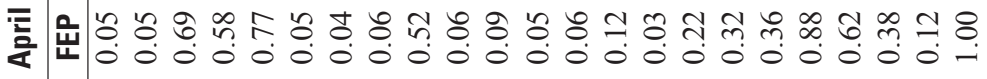

毛能

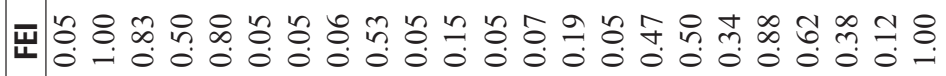

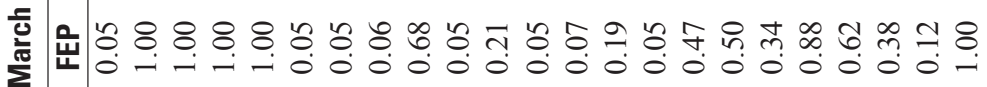

때

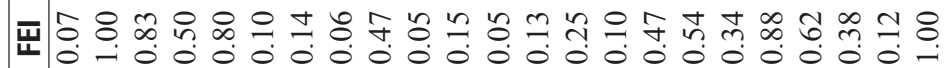

宽

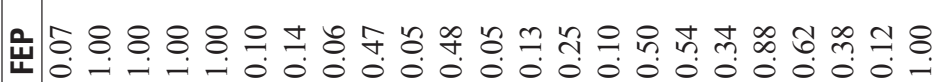

巳

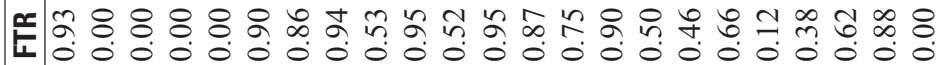

ш

壳

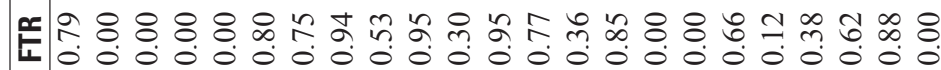

흔으 $-n m+n$ ก 
廿 ڤั

눈 \& \& \& \&

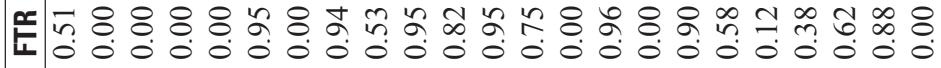

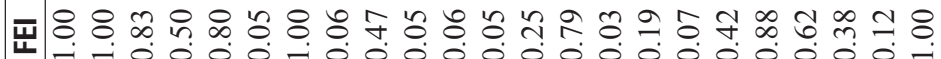
을

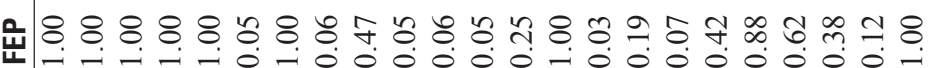

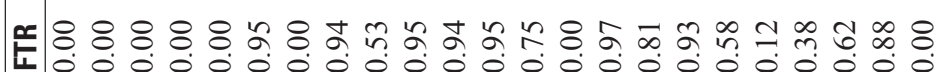

ш \& \&

廿

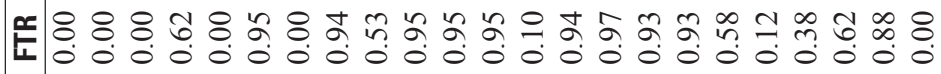

ш के

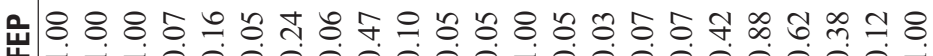

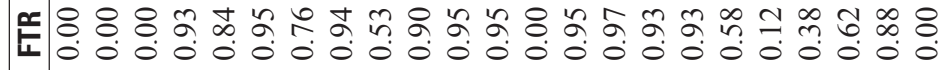

廿

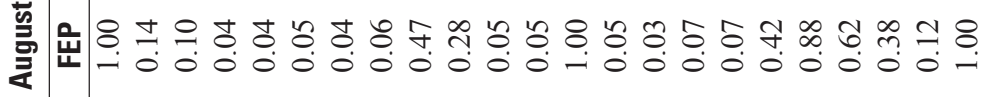

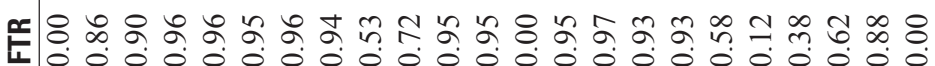

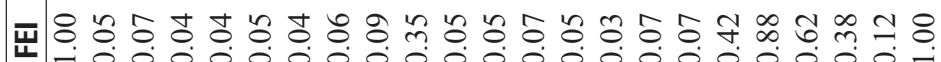

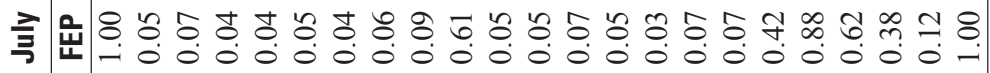

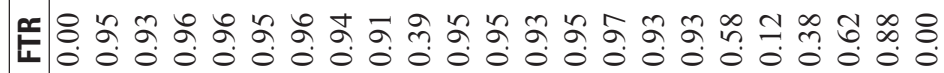

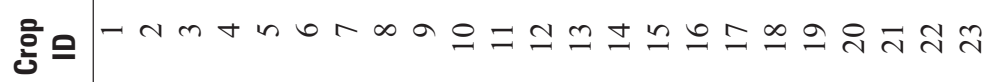



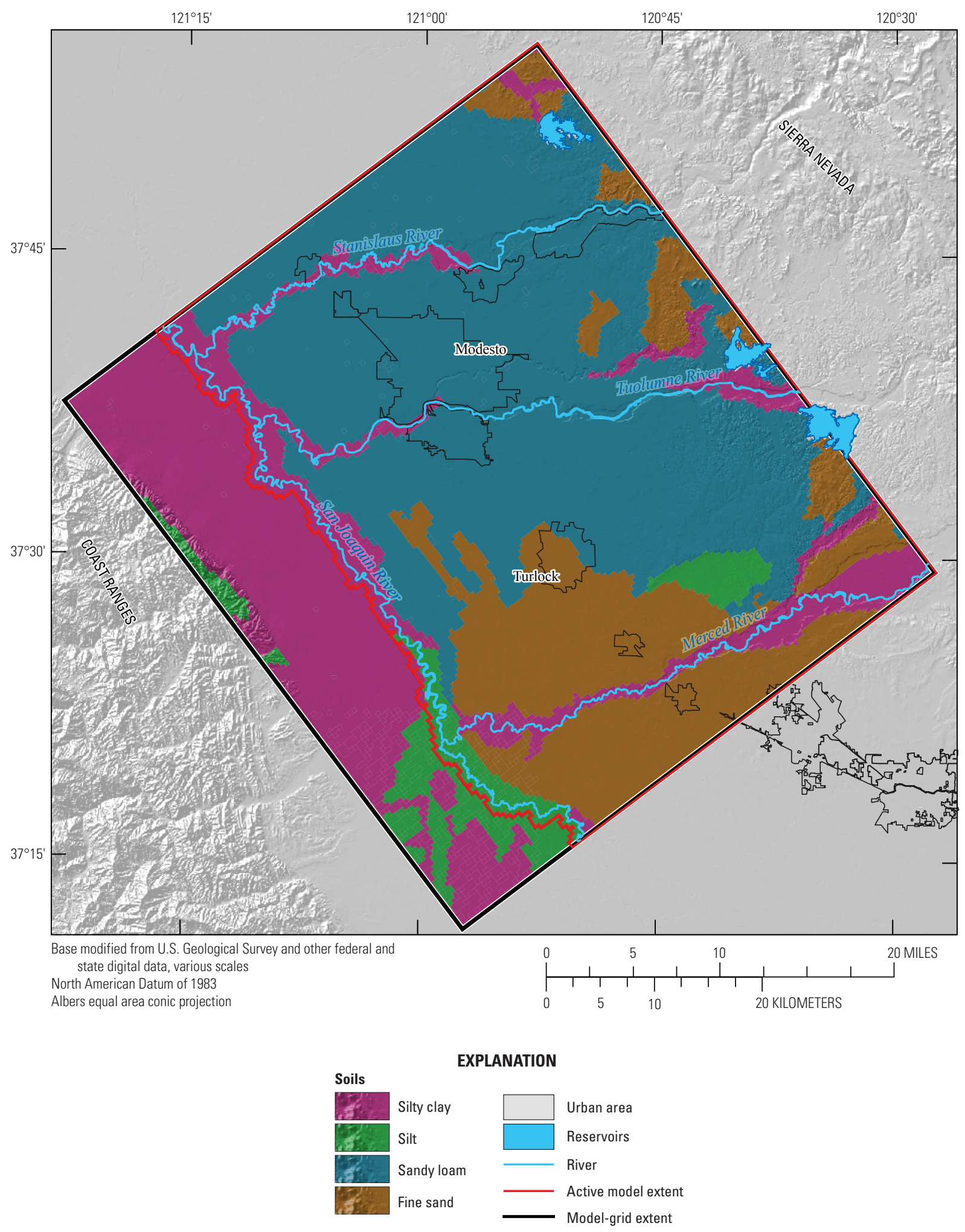

Figure 11. Generalized soil distribution for the Modesto region, California. Derived from STATSGO data (U.S. Dept. of Agriculture, Natural Resources Conservation Service, http://websoilsurvey.sc.egov.usda.gov/App/HomePage.htm, accessed in 2007). 

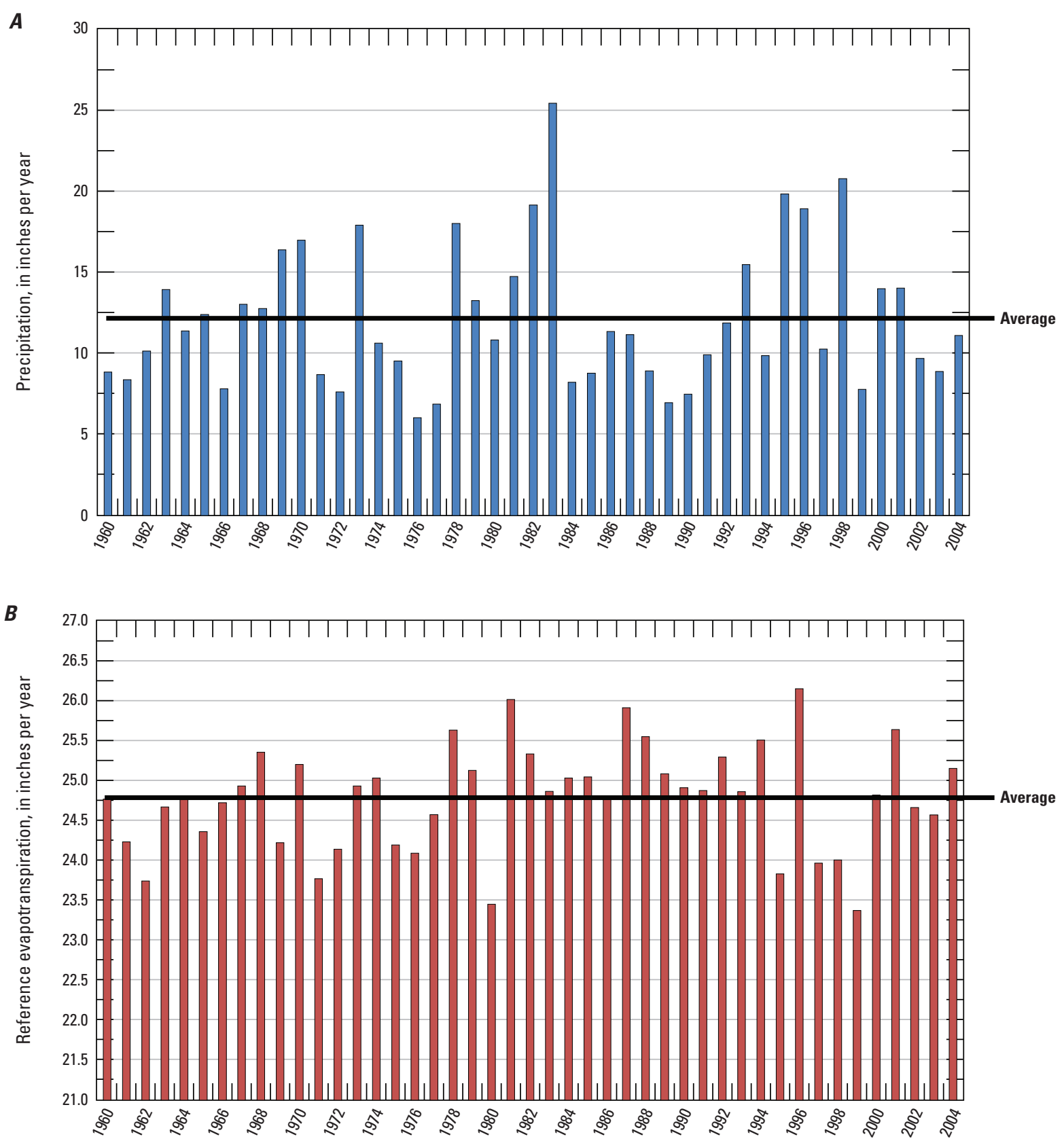

Figure 12. Annual totals for 1960-2004, Modesto region, California, of $A$, precipitation and $B$, reference evapotranspiration.

\section{Evapotranspiration}

Evapotranspiration is calculated by the Farm Process in the MERSTAN model on the basis of reference evapotranspiration and crop coefficients. The product of these values for each model cell represents the potential evapotranspiration, which is the amount of surface evaporation and plant transpiration there would be with sufficient available water. The crop coefficients used are discussed in the "Crop Coefficients" section of this report. Reference evapotranspiration was calculated by using the method developed by Hargreaves and Samani $(1982,1985)$, which uses minimum and maximum daily air temperatures, obtained for this study from PRISM (http://www.prism.oregonstate. edu/), to estimate solar radiation and, in turn, reference evapotranspiration.

The calculated average annual reference evapotranspiration for the study area from 1960 to 2004, including all land uses, is shown in figure 12B. Annual reference evapotranspiration rates ranged narrowly, from about 23.4 to $26.2 \mathrm{in}$./yr, averaging about $24.8 \mathrm{in}$. Average monthly values of reference evapotranspiration for the study area ranged greatly; they were lowest in January and December, at about 0.6 in., and peaked in July at about 4 in. (fig. 13). 


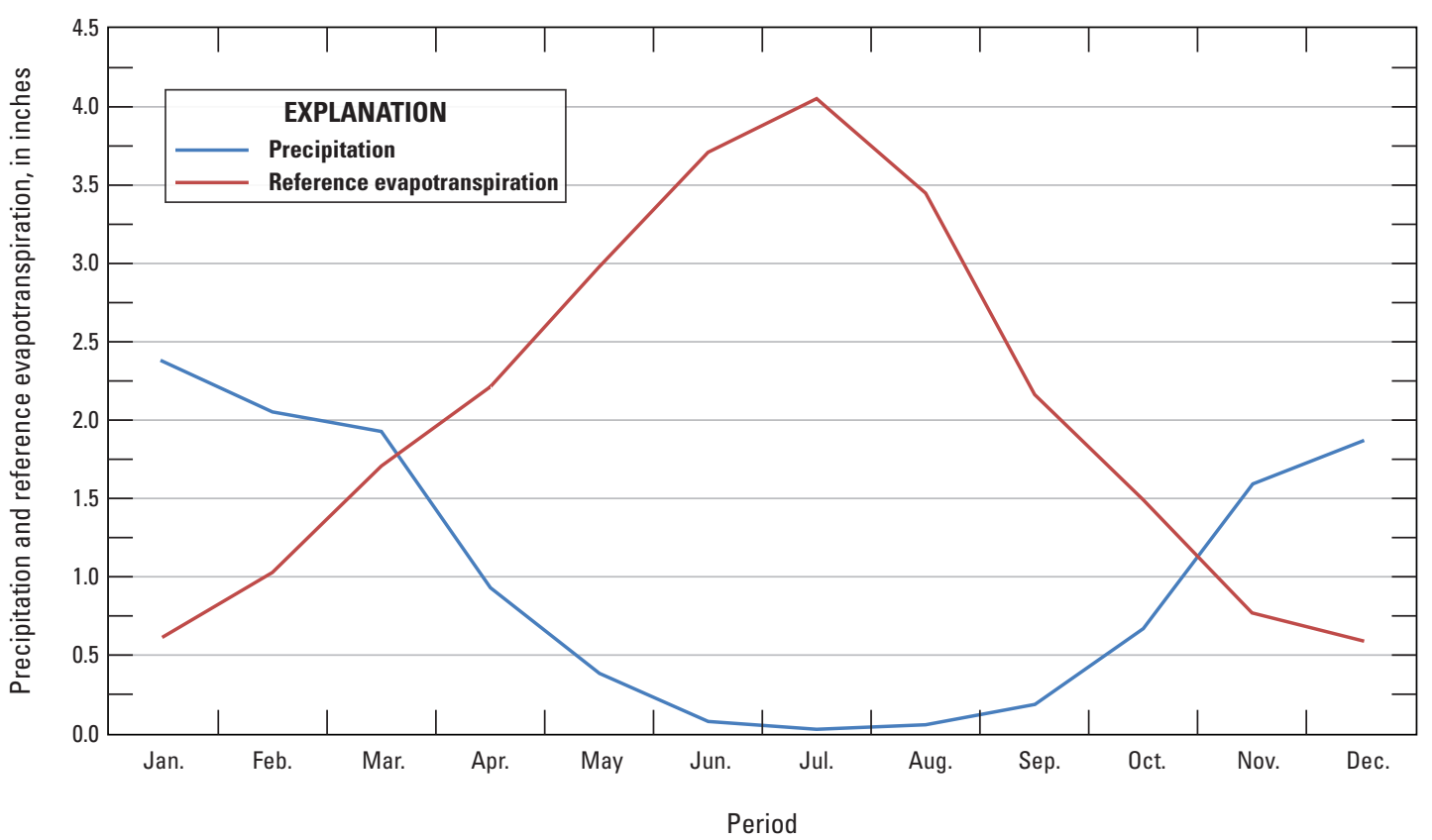

Figure 13. Average monthly precipitation and reference evapotranspiration, 1960-2004, Modesto region, California.

\section{Irrigation Water Supply}

Water delivered for agricultural irrigation in the study area is primarily surface water from Don Pedro Reservoir and other reservoirs, supplemented by groundwater extracted from district-owned wells and privately owned wells under contract with irrigation districts. A subset of the district-owned wells in Modesto and Turlock Irrigation Districts (ID) is used for drainage; most of the water pumped from these wells is discharged to delivery canals and is, therefore, included as part of the irrigation-water supply.

The amount of water delivered for irrigation is imprecisely known, because delivery is a manual process done by a "ditch tender" that consists of opening and closing valves along delivery canals to allow flow into ditches or other on-farm structures used to route water to a variety of irrigation systems. The time during which water flows through these valves is used as a proxy for the estimated volume delivered, and the potential error is substantial. There also is substantial error in the volume released from reservoirs and discharged into rivers at the end of canals.

Modesto, Oakdale, and Turlock Irrigation Districts provided estimates of deliveries by ditch-tender area, allowing for incorporation of spatial variability of deliveries in the MERSTAN model. Modesto ID assumes that actual deliveries are about 20 percent greater than as-billed values
(Walter Ward, Modesto Irrigation District, oral commun., July 2007). Turlock ID estimated that actual deliveries exceeded as-billed deliveries by about 8-35 percent from 1990 to 2001, with an average of about 21 percent (written commun., Debra Liebersbach, Turlock Irrigation District, June 2007); deliveries outside of this period were assumed to exceed as-billed values by 21 percent for this study. Oakdale ID made no adjustment to their as-billed deliveries.

Irrigation deliveries for the portion of Merced Irrigation District in the MERSTAN model were assumed proportional, by area, to deliveries for Merced ID as a whole. Irrigation deliveries for all of South San Joaquin Irrigation District were available for the periods 1960-80 (written commun., Eric Thorburn, Oakdale Irrigation District, April 14, 2014) and 1989-2004 (South San Joaquin Irrigation District, http://www.ssjid.com/district-services/agriculture-irrigationwater.htm, accessed April 14, 2014). South San Joaquin ID deliveries for the period 1981-88 were estimated on the basis of data from 1980 and 1989 and of the trend in delivery data for Modesto ID during the period. It was assumed that the percentage of total South San Joaquin ID deliveries available to the portion of the district in the MERSTAN model area was proportional to the area of South San Joaquin ID in the model. The remaining agricultural areas in the model area did not receive deliveries or sporadically received minor amounts, not accounted for in the model. 
The resulting annual irrigation deliveries and average monthly deliveries are shown in figure $14 A$ and $14 B$, respectively, for 1960-2004. On average, about 1.1 million acre-ft/yr of water was delivered for irrigation purposes during this period; the equivalent application rate varied spatially; for example, in 2004 it ranged from a low of about $0.24 \mathrm{ft} / \mathrm{yr}$ in the southern portion of the study area to greater than $4 \mathrm{ft} / \mathrm{yr}$ in parts of Oakdale and Modesto Irrigation Districts (fig. 15). Annual variations in deliveries were substantial, ranging from about 930,000 acre-ft in 1998, a wet year (fig. 12) that had relatively high rainfall during the spring months (within the growing season), to about 1,450,000 acre-ft in 1984, a dry year; (fig. 12) that followed the wettest year during 19602004, thereby enabling enhanced surface-water deliveries (fig. 14A). Average monthly deliveries from 1960 to 2004 began during March and ended in October, peaking in July (fig. 14B).
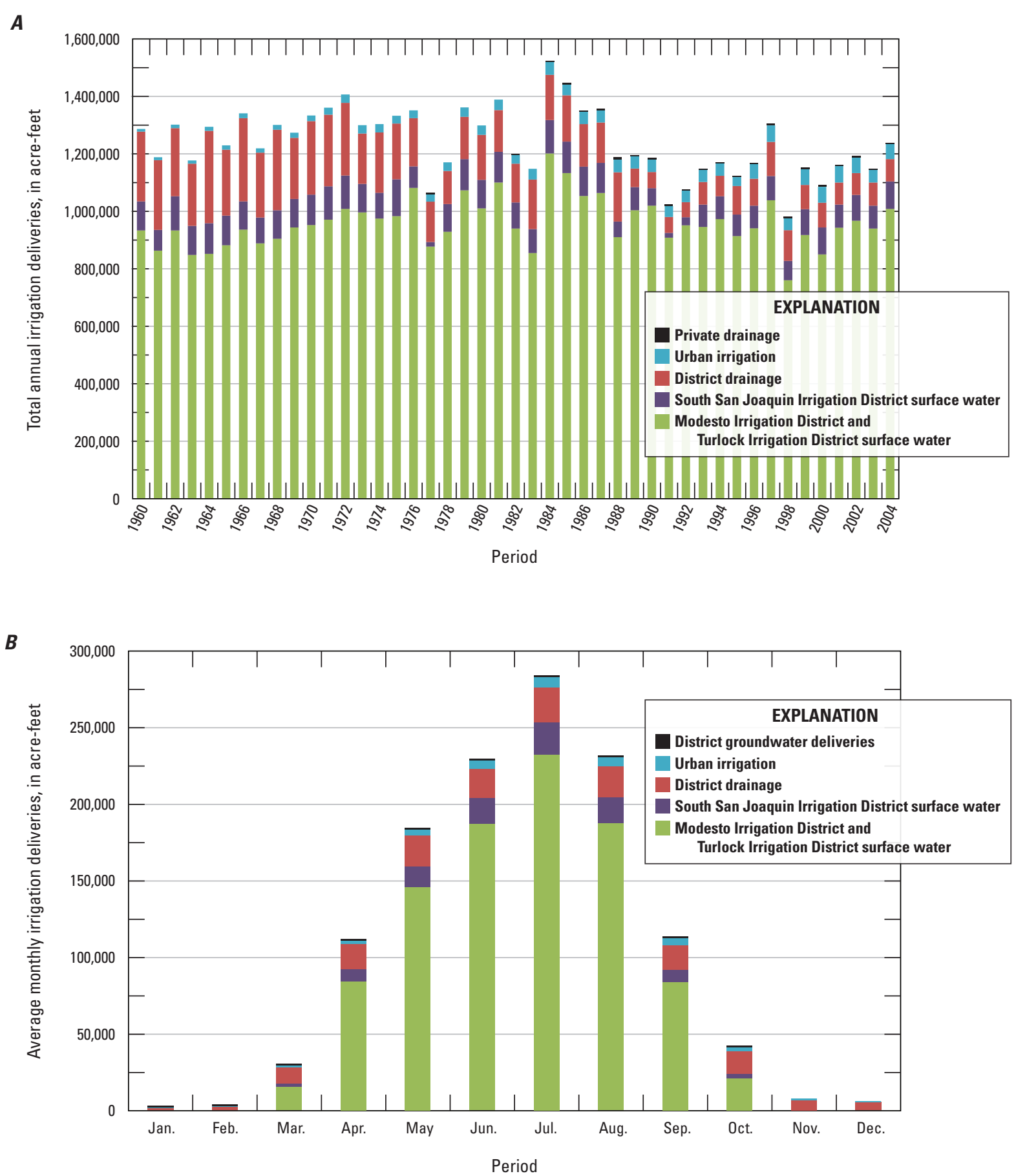

Figure 14. Irrigation deliveries, 1960-2004, for the Modesto region, California: $A$, total annual and $B$, average monthly. Modesto Irrigation District, MID; Turlock Irrigation District, TID; South San Joaquin Irrigation District, SSJID. 


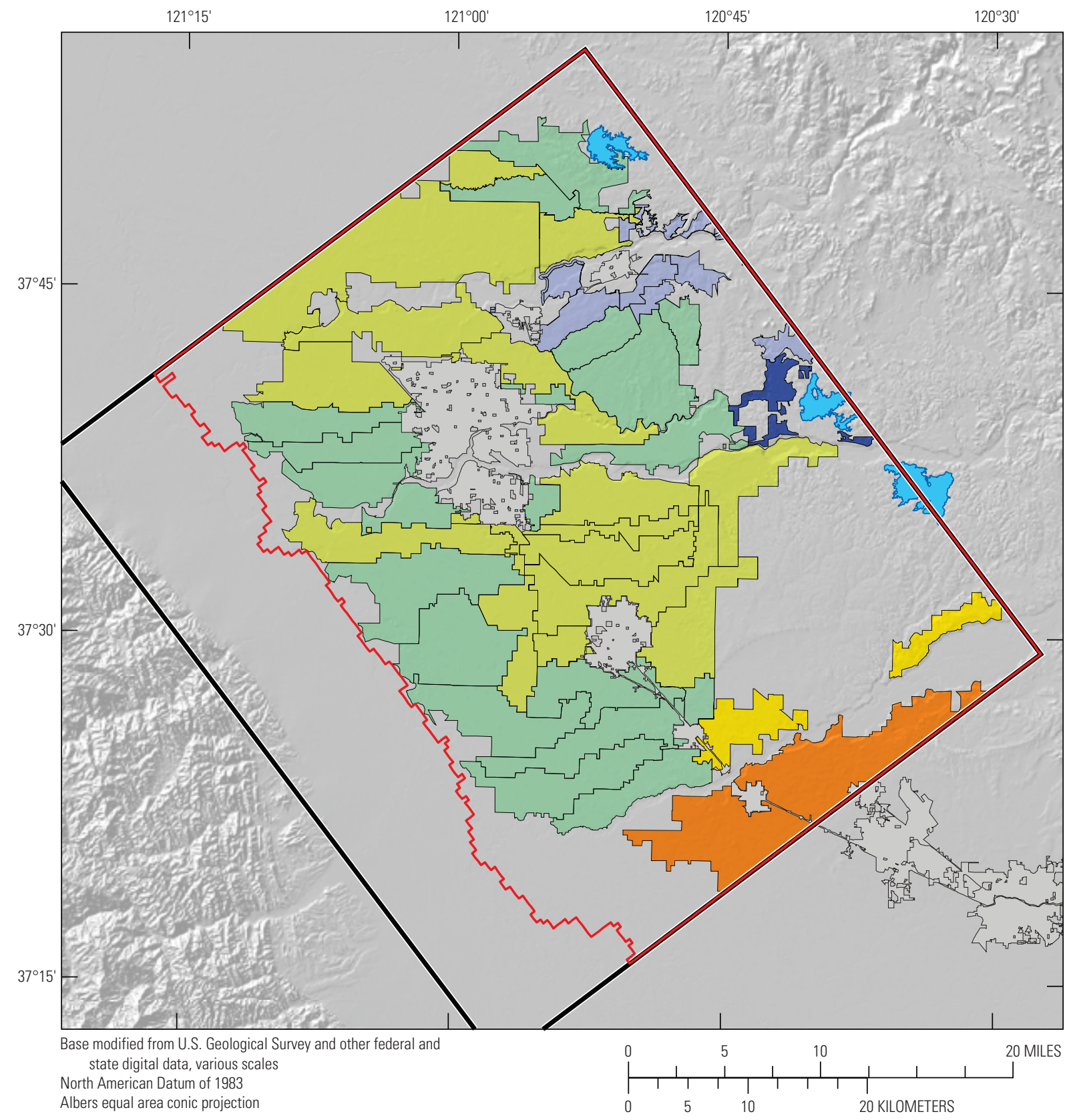

\section{EXPLANATION}

Irrigation delivery rate, in feet per year

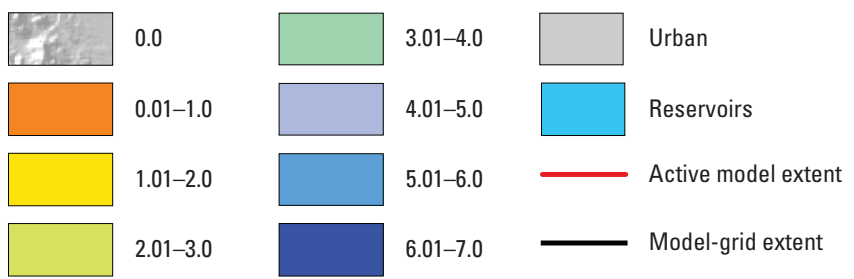

Figure 15. Reported irrigation deliveries, converted to rates, for agricultural water-balance subregions of the MERSTAN model that received deliveries, water year 2004, Modesto region, California. 


\section{Development of Hydrologic Model}

The MERSTAN hydrologic model was developed to simulate the groundwater and surface-water hydrology of the agriculturally dominated Modesto region from 1960 to 2004 to aid the STRGBA evaluate future water-management strategies. The MERSTAN model uses MODFLOW-OWHM (Hanson and others, 2014), with the Farm Process, to simulate the flow and interaction of groundwater and surface water, recharge, groundwater pumping, and other processes associated with irrigated agriculture and other features on the landscape. A steady-state model of the same area, representing water year 2000, was documented by Phillips and others (2007). This steady-state model did not include the Farm Process or route surface water, and used a previous version of MODFLOW; however, some components, including the sediment-texture model used to define the distribution of hydraulic conductivity, were used in the MERSTAN model and are described generally in this report.

The overall hydrologic complexity of the MERSTAN model, combined with finely discretized layers and the need for numerical stability during model calibration, necessitated the simulation of all model layers as confined. To represent unconfined storage, the layer containing the water table, based generally on interpolated measurements from spring 2000 (fig. 6), was assigned a value of specific yield divided by the layer thickness. This value was then multiplied by the layer thickness in MODFLOW-OWHM, resulting in the specific yield. For an unconfined aquifer, the effective (saturated) thickness and, thus, the transmissivity change with a change in head. The simulation of unconfined aquifers as confined assumes that the saturated thickness and, thus, the transmissivity do not change with a change in head. This assumption is good for areas where head change in the unconfined aquifer is small relative to the aquifer thickness (Sheets and others, 2015). For the MERSTAN model, the potential error associated with simulating unconfined aquifers as confined was greatest in the vicinity of Eastside Water District (fig. 7), where a cone of depression (fig. 6) developed primarily during 1960-2004. All model cells above those containing the spring 2000 water table were inactive.

\section{Spatial and Temporal Discretization}

The MERSTAN model area is in the northeastern San Joaquin Valley, extending from north of the Stanislaus River to south of the Merced River; it is bounded on the northeast by the foothills of the Sierra Nevada and on the southwest by the San Joaquin River. The model grid is oriented parallel to the valley axis, 37 degrees west of due north (fig. 1). The model grid extends $38 \mathrm{mi}$ along the valley axis and $34 \mathrm{mi}$ from the Coast Ranges to the foothills of the Sierra Nevada, although most of the area west of the San Joaquin River was not simulated. Each model cell is $1,312 \mathrm{ft}(400 \mathrm{~m})$ by $1,312 \mathrm{ft}$, or about $0.25 \mathrm{mi}$ square; the grid has 153 rows and 137 columns.
The model has a series of wedge-shaped layers to generally represent the regional dip of the sediments (fig. 16). Sixteen model layers were defined, ranging in thickness from about 1.3 to $53 \mathrm{ft}$ above the Corcoran Clay (excluding the uppermost model layer) and from about 68 to $242 \mathrm{ft}$ below the Corcoran Clay. Layer thicknesses generally were designed to increase with depth and decreasing availability of sediment texture data. The top of the uppermost model layer represents the land surface, and the bottom is a smoothed version of the land surface; the thickness of layer 1 ranges from about 3.3 to $91 \mathrm{ft}$. The thickest cells in layer 1 are near the foothills and generally are not saturated. The thicknesses of layers 2 through 7 were assigned as a percentage of the remaining thickness between the bottom of layer 1 and the top of the Corcoran Clay (10, 10, 15, 20, 20, and 25 percent of that thickness, respectively).

Layer 8 represents the Corcoran Clay, where present, the top surface of which was a smoothed rendition constrained by using data from drillers' logs. The thickness of the Corcoran Clay varies spatially, as determined by Page (1986) and from analysis of logs, and ranges from about 10 to $140 \mathrm{ft}$. A thickness of $16.4 \mathrm{ft}(5 \mathrm{~m})$ was specified in layer 8 where the Corcoran Clay was not present. The thickness of layers 9-16 was assigned as a percentage of the thickness of materials between the bottom of the Corcoran Clay and the bottom of the model. Layers 9-16 were 10, 10, 10, 10, 10, 15, 15, and 20 percent of that thickness, respectively. The bottom of the model was an artificial surface that loosely represented topographic variability, the general dip of the Corcoran Clay, and exceeded the depth of wells in the study area. The total thickness of the wedge-shaped volume represented by the model ranged from about 720 to $1,410 \mathrm{ft}$.

The MERSTAN model was temporally discretized into 540 monthly stress periods from January 1960 through December 2004. The first stress period was divided into three time steps; the remainder were divided into two time steps. The length of each time step was determined by a time-step multiplier of 1.1, such that the first time step was shorter than the next.

\section{Initial Conditions}

The initial conditions for the MERSTAN model are hydraulic-head values (equivalent, for purposes of this discussion, to water-level altitude measured in open wells) for each model cell. These values are sometimes generated by using a steady-state model representing the initial period, but this method was not used for this study. Alternatively, measured water levels in wells approximating the water table in the study area were mapped, interpolated, and adjusted to estimate 1960 water-table conditions. These values were assigned to all model layers. Subsequently, the MERSTAN model was run using 1960 hydrologic conditions to allow for equilibration of heads, which occurred within one year. The resulting head values were used as the initial condition. 


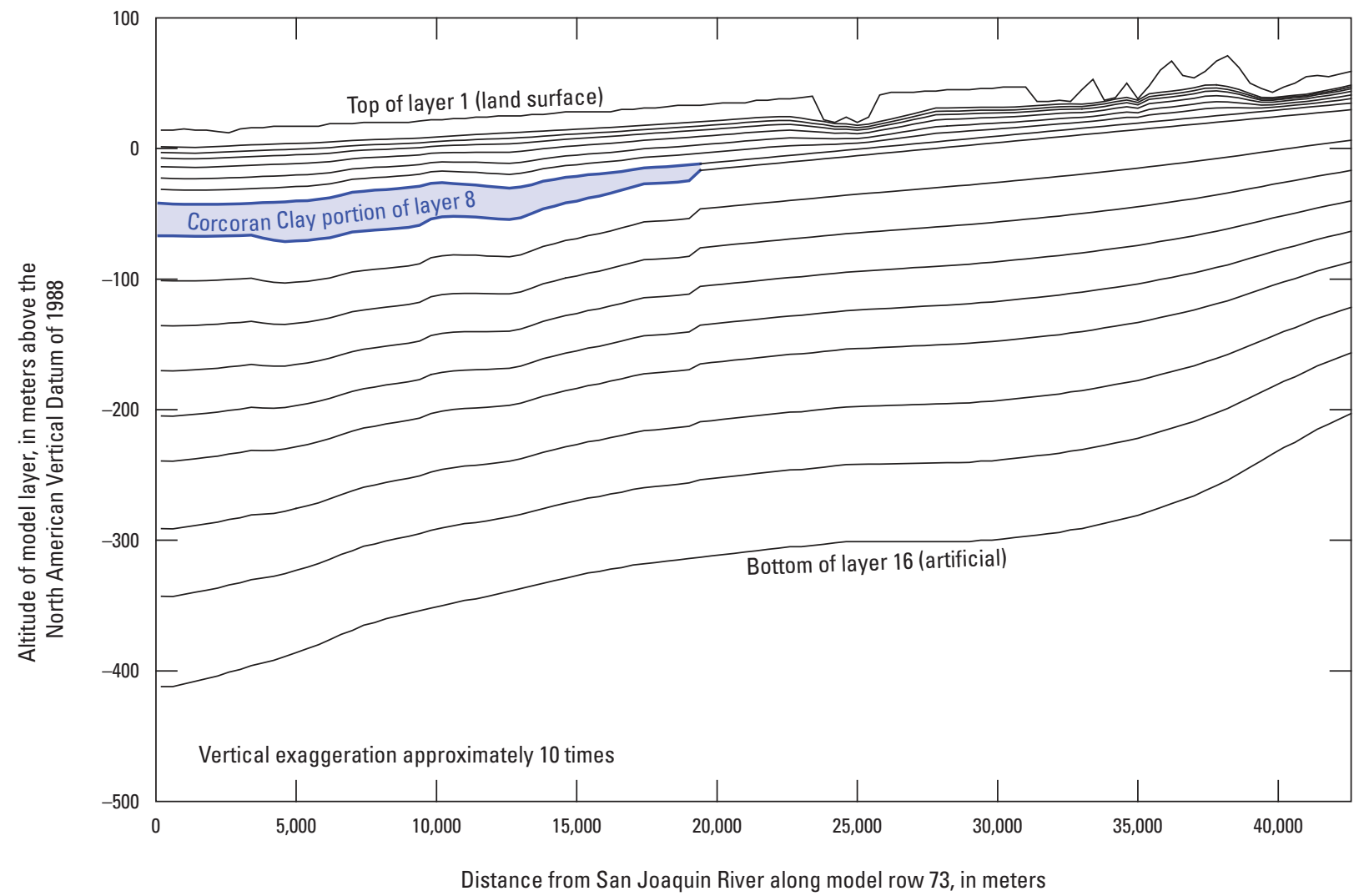

Figure 16. Vertical discretization of MERSTAN model along row 73, Modesto region, California. Location of cross-section along row 73 is shown in figure 1.

This process was repeated as model parameters were adjusted during model calibration, ensuring initial conditions that were consistent with the calibrated parameter set.

\section{Boundary Conditions}

The lateral boundaries of the MERSTAN model varied substantially with respect to hydrologic conditions and data availability for characterization. The lateral boundaries were simulated as no-flow along the foothills of the Sierra Nevada and as general-head elsewhere (fig. 17). Potential recharge in the foothills of the Sierra Nevada, and subsurface flow into the model area, is unknown. Because of a lack of data northeast of the model area and the likely contrast in recharge between developed agricultural areas in the model compared with undeveloped areas to the northeast (these areas were developed after 2004, but were undeveloped during the study period), this boundary condition was simulated as no-flow. This no-flow assumption was considered adequate for the primary purpose of the model - to evaluate the relative effectiveness of alternative water-resources management actions.
A general-head boundary allows for flow across the boundary, in or out of the model area, on the basis of the simulated head next to the boundary, a specified head outside of the boundary, and a conductance value. The general-head boundaries on the northwest and southeast (fig. 17) edges of the model area were specified by using long-term waterlevel records for wells near these boundaries. These specified heads were defined at a distance of about $3 \mathrm{ft}(1 \mathrm{~m}$, or one unit) outside of the model boundary. The conductance value was calculated as the product of the horizontal hydraulic conductivity of the cell, as described in the "Hydraulic Conductivity" section of this report, and the area of the cell face along the boundary (divided by the 1-m distance from the boundary). Along the northwest boundary, measured water levels in multiple wells at various locations and screened intervals indicated a typical downward vertical gradient of about 0.05 . Accordingly, a downward vertical gradient of 0.05 was applied along this general-head boundary from layers 1 through 9; layer 9 was the approximate average location of production-well perforations in the region. Below layer 9, the same gradient was assigned in an upward direction; the maximum head below layer 9 was constrained to that of the water table in the same row and column of the model grid. 


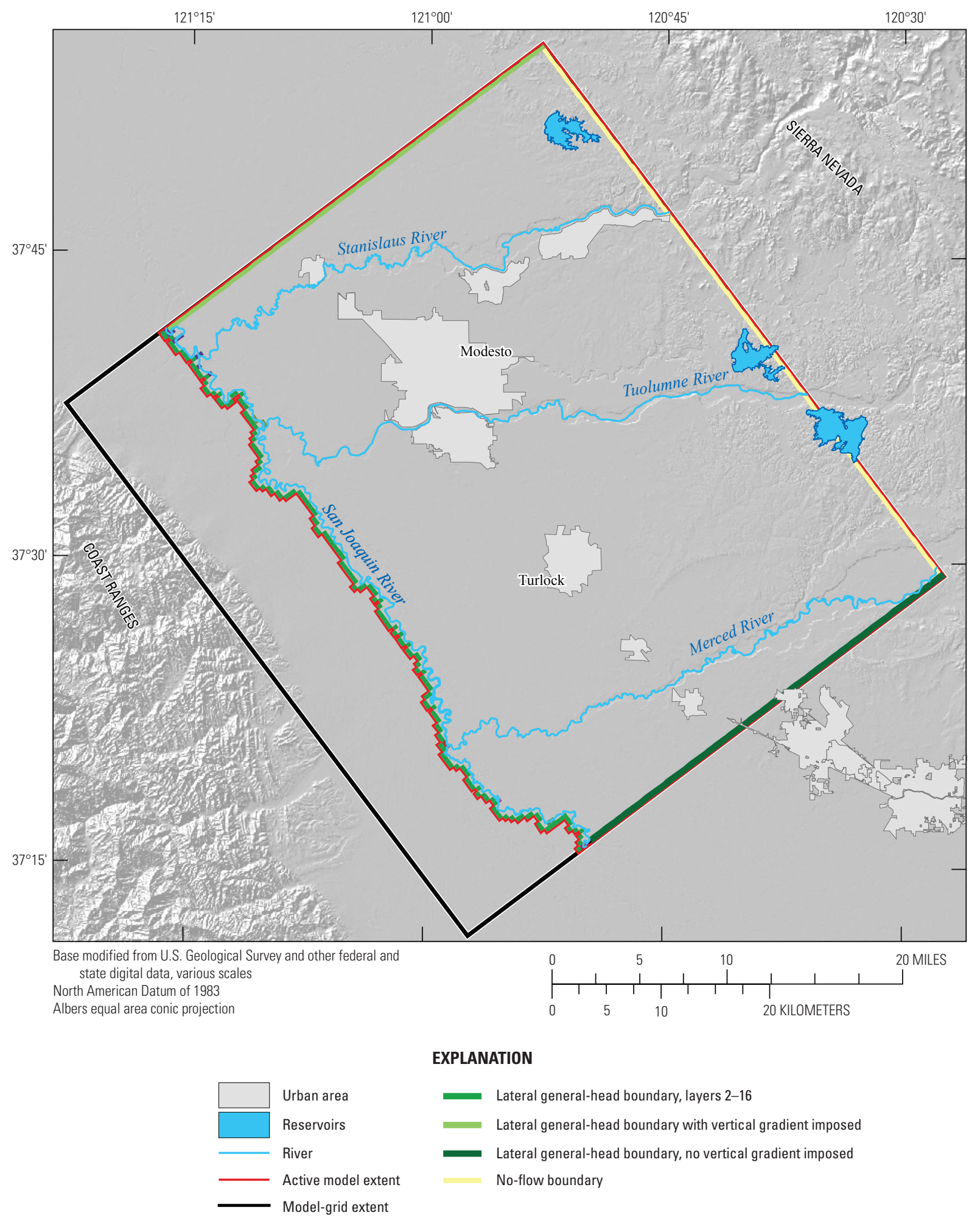

Figure 17. Boundary conditions for the MERSTAN model, Modesto Region, California. 
The southwestern boundary of the MERSTAN model is along the San Joaquin River, and was simulated as a generalhead boundary; all cells west of the boundary were inactive. This configuration allowed for the known potential for crossvalley flow, in both directions, beneath the San Joaquin River (Phillips and others, 1991; Belitz and Phillips, 1995). The general-head boundary was in layers 2-16, one cell southwest of the cells representing the river (fig. 17); the cells in layer 1, above the boundary, were inactive. Groundwater and surface water along the San Joaquin River, therefore, can interact between cells representing the river and active model cells inside the southwestern boundary. The head values specified for the general-head boundary were based on the gradient of the river stage and a calibrated altitude offset. Wells and waterlevel data were sparse near the San Joaquin River; therefore, a vertical gradient was not imposed along the southwestern general-head boundary.

The upper boundary of the model was the water table as approximated by simulating confined conditions (needed for numerical stability) by using unconfined storage values. The lower model boundary was arbitrarily located far below the deepest wells and was simulated as no-flow; flow at that depth having importance to the intended purpose of the model was considered unlikely.

Hydrologic stresses on the aquifer system associated with various other forms of groundwater recharge and discharge are discussed in other sections of this report. These include recharge from irrigation return flow, precipitation, seepage from rivers, and reservoir leakage and discharge from wells, to rivers, by plant uptake, and by evaporation of shallow groundwater.

\section{Simulation of Irrigated Agriculture and other Landscape Processes}

Irrigated agriculture and other landscape processes were simulated in the MERSTAN model by using the Farm Process in MODFLOW-OWHM (Hanson and others, 2014). The Farm Process represented the entire land area in the MERSTAN model, excluding the streams and reservoirs. Areas of natural vegetation and non-irrigated agriculture were included. The primary input data for the Farm Process are described in the "Irrigated Agriculture and Other Landscape Data" section of this report. The calculations used in the Farm Process are described generally in this section; more detailed descriptions are provided by Schmid and others (2006), Schmid and Hanson (2009), and Hanson and others (2014).

\section{Water Demand}

The monthly water demand associated with the landscape was calculated by the Farm Process for each model cell on the basis of land use. Whether natural, agricultural, or urban, the plants drive the landscape water demand. Only impervious urban areas and fallowed land were assumed to have no landscape water demand. For a given model cell, the monthly potential evapotranspiration was calculated from the reference evapotranspiration and a crop coefficient representing the dominant land use in the cell, as described in the "Evapotranspiration" section of this report. The potential evapotranspiration was then adjusted on the basis of monthly crop cover and irrigation uniformity - the greater fraction of cropped area covered by the plant, the greater the transpiration, and the lower the evaporation. More uniformly applied irrigation results in more evaporation than targeted irrigation. These adjustments are described in the "Transpiratory and Evaporative Fractions of Consumptive Use" section of this report.

Other factors affect water demand, including runoff of irrigation and precipitation, soil saturation conditions, and irrigation efficiency. Runoff is calculated by the Farm Process in the MERSTAN model on the basis of land-surface gradient, which generally was low, but there can be some runoff near the northeastern boundary in the lower part of the foothills. There is a feature in the Farm Process for adjusting transpiratory demand on the basis of soil saturation, allowing for decreased demand at the wilting point and under anoxic conditions, which can result from waterlogging. For this regional application of the Farm Process, where small errors in simulated water-table altitude over a large region of shallow groundwater could greatly reduce agricultural water demand through anoxia, this feature was disabled. The reasonable underlying assumption in disabling this feature is that farmers manage their irrigation to avoid wilting and anoxia.

A key factor when calculating water demand in irrigated areas is the irrigation efficiency, as described in the "Irrigation Efficiency" section of this report. The assigned irrigation efficiency for most of the study area was relatively low, in the 50-65 percent range (table 1), which means that 35-50 percent of the applied water was not used by plants. Therefore, the water required for irrigation must increase by a factor of the reciprocal of the irrigation efficiency (expressed as a fraction) to satisfy the transpiratory demand. For example, at an irrigation efficiency of 50 percent, the water demand is doubled and is increased by a factor of 1.54 at an irrigation efficiency of 65 percent.

Urban landscape demand was calculated on the basis of turf as the "crop," and was scaled by the percentage of pervious surface in the urban areas (table 1) by adjusting the crop coefficients (table 2).

The landscape water demand for individual cells in the model were aggregated in the Farm Process by water-balance subregion. This demand by subarea was then met by various sources of water supply. 


\section{Water Supply}

The potential supplies of water to meet demands of the landscape include precipitation, groundwater uptake by plants, deliveries of surface water and groundwater by irrigation districts, and private irrigation pumping. Each of these water sources in the MERSTAN model was accounted for in the Farm Process.

\section{Precipitation}

The portion of monthly precipitation input by model cell (see "Climate" section of this report) that exceeded soil moisture capacity was used by the Farm Process as a potential source of water to meet transpiratory demand. Most precipitation in the study area, which averaged about $12 \mathrm{in./yr} \mathrm{(fig.} \mathrm{12),} \mathrm{falls} \mathrm{during} \mathrm{the} \mathrm{winter} \mathrm{months,} \mathrm{when}$ transpiratory demand generally is low (fig. 13), but occasional storms in the spring and fall help to meet demand. A small percentage of precipitation runs off, particularly near the northeastern boundary, as calculated by the Farm Process on the basis of land-surface gradient.

\section{Groundwater Uptake by Plants}

In areas where the water table is shallow and the capillary fringe reaches into the root zone, the Farm Process simulates groundwater uptake by plants. The capillary fringe is determined by soil type, which was specified throughout the study area (fig. 11). As the simulated water table rises, uptake begins when the capillary fringe reaches the root zone and increases linearly to a maximum rate as the water table reaches the root zone (Schmid and others, 2006).

\section{Deliveries of Surface Water and Groundwater}

Irrigation districts in the study area deliver surface water and, in some cases, groundwater from drainage wells and district-owned or rented private wells (fig. 14). There are various options in the Farm Process for routing these deliveries; for the MERSTAN model, the non-routed delivery option was used, which simply provides specified deliveries to particular water-balance subregions on a monthly basis. If deliveries exceed water demand, the excess water is not used, or is "rejected." Rejected deliveries are discussed further in the "Model Results" section of this report.

\section{Estimation of Private Irrigation Pumpage}

Private irrigation pumpage was unknown in the study area, and in most of California, which was a primary reason the Farm Process was developed - to provide a better means for estimating this important component of water supply. The Farm Process, first, accounts for all other water sources available in a water-balance subregion to meet transpiratory demand, starting with precipitation and groundwater uptake.
Deliveries, where available, are then used to offset demand. Any residual transpiratory demand is assumed to be met by private irrigation pumping.

\section{Simulation of Groundwater System}

Aquifer-system hydraulic properties and stresses associated with groundwater recharge and discharge in the MERSTAN model are discussed in this section.

\section{Hydraulic Properties of the Aquifer System}

Hydraulic properties of the aquifer system depicted in the MERSTAN model include the horizontal and vertical hydraulic conductivities and storage properties associated with each model cell. The hydraulic conductivity of the aquifer material in a model cell governs its ability to transmit water through its porous matrix. Specific yield $(S y)$ for unconfined aquifers and the storage coefficient $(S)$ for confined aquifers represent the water yielded from that material under a unit change in hydraulic head. $S y$ is governed by the ratio of water yielded by gravity drainage of pore spaces when the water table declines to the total volume of the drained aquifer material. $S y$, which is generally slightly less than the porosity of the unconfined aquifer material, typically ranges from near zero for clay more than 0.4 for coarse sand and gravel (Johnson, 1967). Typically, $S$ is orders of magnitude less than $S y$, because the pore spaces remain saturated, and the water yield is governed by the thickness of the aquifer, the compressibility of the aquifer-system matrix, the compressibility of the fluid, and the porosity of the fluid-filled material. Specific storage $(S S)$, the value specified in the model for confined parts of the aquifer system, is $S$ divided by the aquifer thickness.

\section{Hydraulic Conductivity}

Hydraulic conductivity values in the MERSTAN model were estimated for three parts of the aquifer system: the Corcoran Clay; older, semi-consolidated deposits in the northeastern portion of the model area; and the remaining deposits. The Corcoran Clay, a lacustrine deposit underlying the western portion of the study area (fig. 2), is readily identified in drillers' logs; is well-mapped in the region (Burow and others, 2004); and was assumed to be homogeneous, laterally isotropic with vertical anisotropy. Thus, the vertical hydraulic conductivity of the Corcoran Clay was a constant value in the model, as was the horizontal hydraulic conductivity; the horizontal hydraulic conductivity was allowed to differ from the vertical. These values were estimated during model calibration and compared to previous estimates.

Quaternary Plio-Pleistocene age semi-consolidated (QPC) deposits (Jennings, 1977) along the northeastern part of 
the model area correspond to the Turlock Lake and Mehrten Formations (fig. 2). The hydraulic properties of these deposits were estimated separately from those of the younger alluvium because the relative consolidation of the QPC deposits could affect their storage and transmissive properties. The location of the QPC deposits was assumed to be constant with depth; the geologic formation boundaries and extents in the study area are not well understood.

The younger alluvium, a catch-all term for the remaining materials, is a variety of deposits of alluvial and eolian (windblown) origin situated above, below, and northeast of the Corcoran Clay and southwest of the QPC deposits (fig. 2).

The distribution of hydraulic conductivity in the younger alluvium and QPC deposits was governed by the sedimenttexture distribution described in the "Sediment Texture" section of this report and documented by Burow and others (2004). The sediment texture is expressed as the fraction of coarse-grained (and, therefore, fine-grained) materials in each model cell.

Estimation of the horizontal and vertical hydraulic conductivity for each cell on the basis of sediment texture was done following the method developed by Phillips and Belitz (1991) and subsequently adapted for other studies (for example, Phillips and others, 2007; Faunt, 2009). This method involves the definition of end-member values representing the hydraulic conductivities of pure coarse-grained and finegrained materials and uses weighted averages, where the weights are the fractions of coarse- and fine-grained materials, to calculate the horizontal and vertical hydraulic conductivity for each cell. The horizontal hydraulic conductivity was calculated by using a weighted arithmetic mean, and the vertical hydraulic conductivity by using a power mean, which allows the vertical averaging method to vary from the geometric to the harmonic mean. The theoretical basis for the use of these averaging methods is discussed in Phillips and Belitz (1991), and the equations for the weighted arithmetic and power means are shown in Faunt (2009, p. 154). In short, the arithmetic mean highly weights the coarse-grained end member, which makes physical sense for calculating horizontal hydraulic conductivity, because lateral flow through sub-horizontally deposited layers is strongly dependent on the coarse-grained deposits. Similarly, vertical flow is primarily dependent on the presence and fraction of fine-grained materials, and varying from the geometric to the harmonic mean highly weights the fine-grained end member.

The calibration of hydraulic conductivity for the younger alluvium and QPC deposits was done by varying their fineand coarse-grained end-member hydraulic conductivities, which were separate, and the overall power mean.

\section{Storage Properties}

The storage properties in the MERSTAN model were estimated for the same three parts of the aquifer system as for hydraulic conductivity - the Corcoran Clay, the older QPC deposits, and the younger alluvium. There is not an established or direct relation between sediment texture and storage properties, so the texture distribution was not used to define the distribution of storage properties. The storage properties of the three parts of the aquifer system described previously were estimated separately during model calibration; these properties were assumed to be constant within each part of the system.

The storage properties estimated for the MERSTAN model were the specific yields and specific storages of the younger alluvium and QPC deposits and the specific storage of the Corcoran Clay, which was well below the water table in the model area (specific yield did not apply). All layers of the MERSTAN model were simulated as confined, but the equivalent of specific yield was assigned as the storage value for the layers containing the water table in the spring of 2000 to reasonably simulate water-table change.

\section{Recharge}

Groundwater recharges in the model area by deep percolation (past the root zone) of precipitation and irrigation water, seepage from streams, reservoir leakage, and subsurface flow through lateral boundaries. Deep percolation is calculated by the Farm Process on the basis of specified irrigation efficiency and the infiltration of precipitation that exceeds soil moisture capacity (Schmid and others, 2006; Schmid and Hanson, 2009). Seepage from streams, which is discussed in more detail in the "Simulation of Surface-Water System" section of this report, is simulated (external to the Farm Process) for each cell containing a stream on the basis of the relative head in the stream and in the underlying aquifer and the streambed hydraulic conductivity.

Reservoir leakage was specified as a constant value in the MERSTAN model on the basis of available estimates by using the recharge package of MODFLOW (Harbaugh, 2005). Results from a study conducted by the Modesto Irrigation District, which manages the Modesto Reservoir, indicated a leakage rate of about 24,000 acre-ft/yr (Modesto Irrigation District, 1999). The estimated leakage rate for Woodward Reservoir, which is about the same size as Modesto Reservoir, was 22,000 acre-ft/yr (Davids Engineering, Inc., 2012). A leakage rate per unit area was calculated for Modesto Reservoir and used directly for Modesto and Woodward Reservoirs. Turlock Lake straddles the model boundary; the portion in the model was assigned double the leakage rate of the other reservoirs to compensate for the unrepresented area. Numerical instability in the model resulted in a 75 percent reduction of these estimated reservoir recharge rates.

Subsurface flow through the northwest, southeast, and southwest general-head boundaries was simulated on the basis of measured or calibrated (where measured unavailable) heads outside the boundaries and simulated heads within the model. 


\section{Discharge}

Groundwater in the model area discharges by groundwater pumping, base flow to rivers, transpiration and evaporation from the shallow water table, and subsurface flow through lateral boundaries. Groundwater pumpage for urban use, agricultural drainage, and delivery by irrigation districts generally was measured; gaps in the record were estimated as described in the "Hydrologic Setting" section of this report. Domestic groundwater use was assumed to be a small component and was not estimated for inclusion in the model. The categories of groundwater pumpage included in the MERSTAN model were implemented by using the Well Package in MODFLOW (Harbaugh, 2005). Each well was simulated separately and was assigned to one or more model layers on the basis of the known or estimated screened (or perforated) interval of the well. For those wells screened in multiple layers, each monthly value of pumpage was distributed by layer on the basis of the ratio of the effective transmissivity of the well screen in each layer (the length of well screen in a layer multiplied by the horizontal hydraulic conductivity of that layer) to the total effective transmissivity of the entire well screen.

Private irrigation pumpage was estimated by the Farm Process as the water supply needed to meet irrigation demand after accounting for effective precipitation, plant uptake of shallow groundwater, and irrigation deliveries. This was calculated at the scale of water-balance subregions. Because the number and distribution of active agricultural wells were unknown, a grid of virtual farm wells, generally with a well in every other model cell, was generated for irrigated agricultural areas outside of the riparian subareas (which use water from streams). These virtual farm wells were implemented by using a version of the Well Package in the Farm Process; the vertical pumping distribution was specified as described previously on the basis of typical screened intervals of agricultural wells in each water-balance subregion. The total monthly estimated private irrigation pumpage for a water-balance subregion was distributed equally by the Farm Process to the virtual farm wells in that subarea. It is possible to constrain the pumping distribution in the Farm Process by specifying differing well pumping capacities; however, there was no basis for doing so in this application, so these capacities were set to very large, equal values, such that the amount and distribution of pumping was not constrained.

\section{Simulation of Surface-Water System}

The flow of surface water in the San Joaquin River and the three tributaries (Stanislaus, Tuolumne, and Merced Rivers), and its interaction with the aquifer system, was simulated in the MERSTAN model by using the Streamflow Routing Package, version 2 (SFR2; Niswonger and Prudic,
2005). These rivers were represented in the model by 968 cells grouped into 20 reaches (called segments in SFR2), as shown in figure 18. Streamflow was specified at the upstream end of each river at the model boundaries on the basis of data from upstream streamgages (Faunt, 2009). The stage-discharge relations were defined by a rating table for each reach, which included several values of discharge (streamflow) and associated values of stage (altitude of water surface) that were based on in-reach or nearby streamgaging stations. The model linearly interpolated between these points to calculate stage for a given simulated discharge.

To adequately simulate the interaction between groundwater and surface water, the simulated stage must be close to the measured value. Simulated stage was adjusted to match measured stage at streamgages reasonably by making minor adjustments to the estimated altitude of the streambed (derived from topographic maps), for which measurements generally were not available.

The hydraulic conductivity of the streambed, which was specified in SFR2, was estimated during model calibration as two parameters: one for the upper reaches of the tributaries (fig. 18) and one for the remaining (lower) reaches of the tributaries and for the San Joaquin River. Gaged streamflows (particularly downstream) and measured groundwater levels near the rivers informed the calibration of streambed hydraulic conductivity.

\section{Model Calibration and Sensitivity}

Model calibration involves comparing simulated equivalents to measured values, which are called observations in this context, and adjusting model parameters to achieve reasonable agreement between these values. The actual values of model parameters, such as hydraulic properties of the aquifer system or streambed hydraulic conductivity, generally are poorly understood. This highlights the importance of observations of the state of the hydrologic system, which collectively provide a basis for the calibration of parameter values.

The MERSTAN model was calibrated for the purpose of identifying representative parameter values and reasonably matching the historic behavior of the hydrologic system, thereby allowing the evaluation of relative hydrologic effects of various water-management alternatives. A semi-automated calibration process began with determining the relative sensitivity of the model solution to many parameters and reducing the parameter calibration set to those to which the model was most sensitive. These parameters included those associated with aquifer-system hydraulic conductivity and storage properties, streambed hydraulic conductivity, and the hydraulic head for the southwestern general-head boundary condition. 


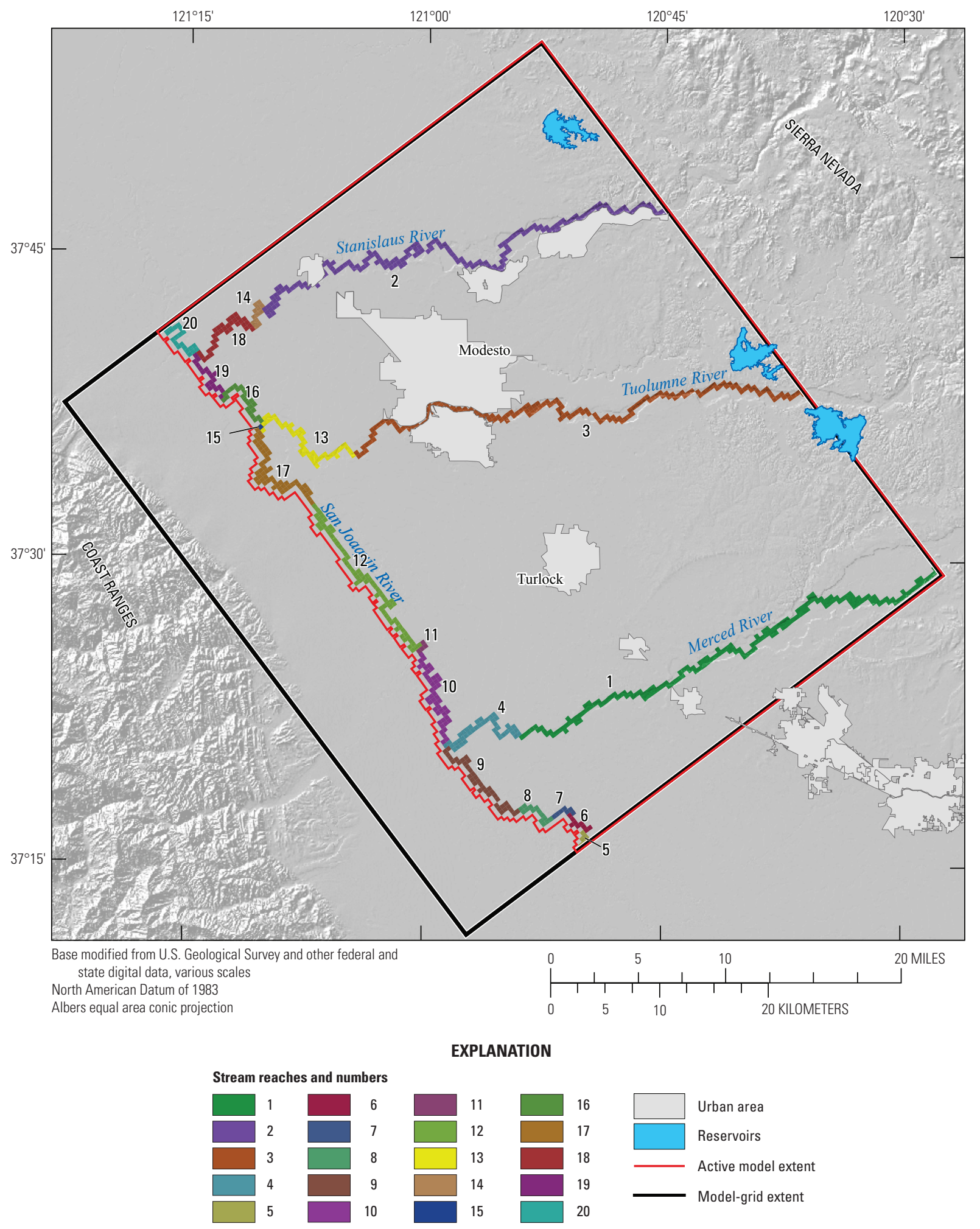

Figure 18. Model cells used to represent rivers, and groups of cells representing river reaches, in the MERSTAN model, Modesto Region, California. 


\section{Calibration Data}

Available observations of the state of the hydrologic system simulated by the MERSTAN model include measurements of groundwater levels in wells and of discharge in streams. A total of 109 wells in the study area (fig. 19) for which there were water-level measurements were selected for model calibration on the basis of length of record, number of measurements, the part of the aquifer system represented, and multiple-depth construction (table 4). These wells represented 4,061 water-level measurements made during 1960-2004. The wells were of various type, including observation, irrigation, drainage, and domestic, and were measured by multiple entities (table 4). The wells were of varying depth and represented the parts of the aquifer system tapped for supply and the water table. Where the water table is near land surface, a subset of 22 (out of 201) shallow (15-ft-deep) wells monitored monthly by the Turlock Irrigation District was included in the calibration set (fig. 19).

The set of groundwater levels was used for model calibration in two ways: direct comparison of measured water level (altitude) to simulated head and comparison of measured and simulated drawdown (change in head). Calibration to head seeks to match the measured water levels, whereas calibration to drawdown seeks to match trends in the measured water levels. These were viewed as equal goals for model calibration.

Streamflow records from six streamgages in the study area were used in model calibration. For each tributary, one streamgage in the lower reaches was used; three streamgages represented the San Joaquin River (fig. 1). Streamflow was calibrated by using 2,739 monthly average measurements; these were compared to simulated monthly values. Four of the six streamgages had a complete record for the simulation period; one was missing about five years, and the other had data only during the final seven years of the simulation period. Streamgages on the lower reaches of the tributaries were selected for calibration because they were distant from specified inflows at the model boundaries. The streamgages on the San Joaquin River included one near the northwestern model boundary where the river exits the model, representing the combined flow of all rivers in the model.

\section{Calibration Process}

The MERSTAN model primarily was calibrated by using PEST, a public-domain nonlinear parameter-estimation algorithm documented in Watermark Numerical Computing (2005). To reduce the runtime of PEST routines, which require many model runs, a version called BEOPEST was used that allows for parallel model runs on many computers (Watermark Numerical Computing, 2010).

Prior to using PEST, initial hydraulic parameters from the previous steady-state model (Phillips and others, 2007) were assigned; initial estimates of storage properties also were assigned. Manual adjustments were made to various parameters to coarsely calibrate the model; this process is called trial-and-error calibration, and it improved the initial parameter values for subsequent PEST runs. Additionally, manual adjustments were made to Farm-Process input to reduce rejected deliveries, which are cases where specified deliveries exceeded crop irrigation demand. Some rejection is to be expected, given annual variability in climatic conditions not reflected in the static distribution of crop coefficients and associated potential evapotranspiration, but initial rejected deliveries were considered too high. A 10-percent increase in all crop coefficients was applied to reduce rejected deliveries to about 11 percent of total deliveries. All information shown in this report with respect to crop coefficients (table 2) and deliveries take this adjustment and the rejected deliveries into account.

For the parameter estimation process, "prior information" was used in PEST to help constrain the storage parameters. This allows PEST to estimate a parameter set that matches the observed data and simulated equivalents best, while taking prior information, or user-specified parameter estimates, into account. The prior information was assigned to ensure that the estimated parameter values fell within ranges that are physically reasonable. When using prior information, PEST attempts to match the observed data while simultaneously matching the prior information values as well as possible. For the specific yield parameters, the prior information value was 0.25 and had a weight of 0.5 ; those for specific storage were $1 \times 10-6$ per foot and had a weight of 5.0.

PEST performs the task of finding the set of parameter values, as constrained by the user, that minimize the error between the observations and their simulated equivalents as well as the error between the simulated parameter values and their prior information value. The error for a given observation is expressed as the difference, or residual, between the simulated value at the observation location and the observed value. A negative residual indicates the model is simulating groundwater altitude or streamflow too low at that location; a positive residual indicates the model is simulating the groundwater altitude or streamflow too high. The value that PEST minimizes, or the objective value, is the sum of the squared residuals, where each residual is multiplied by a userassigned weight. 

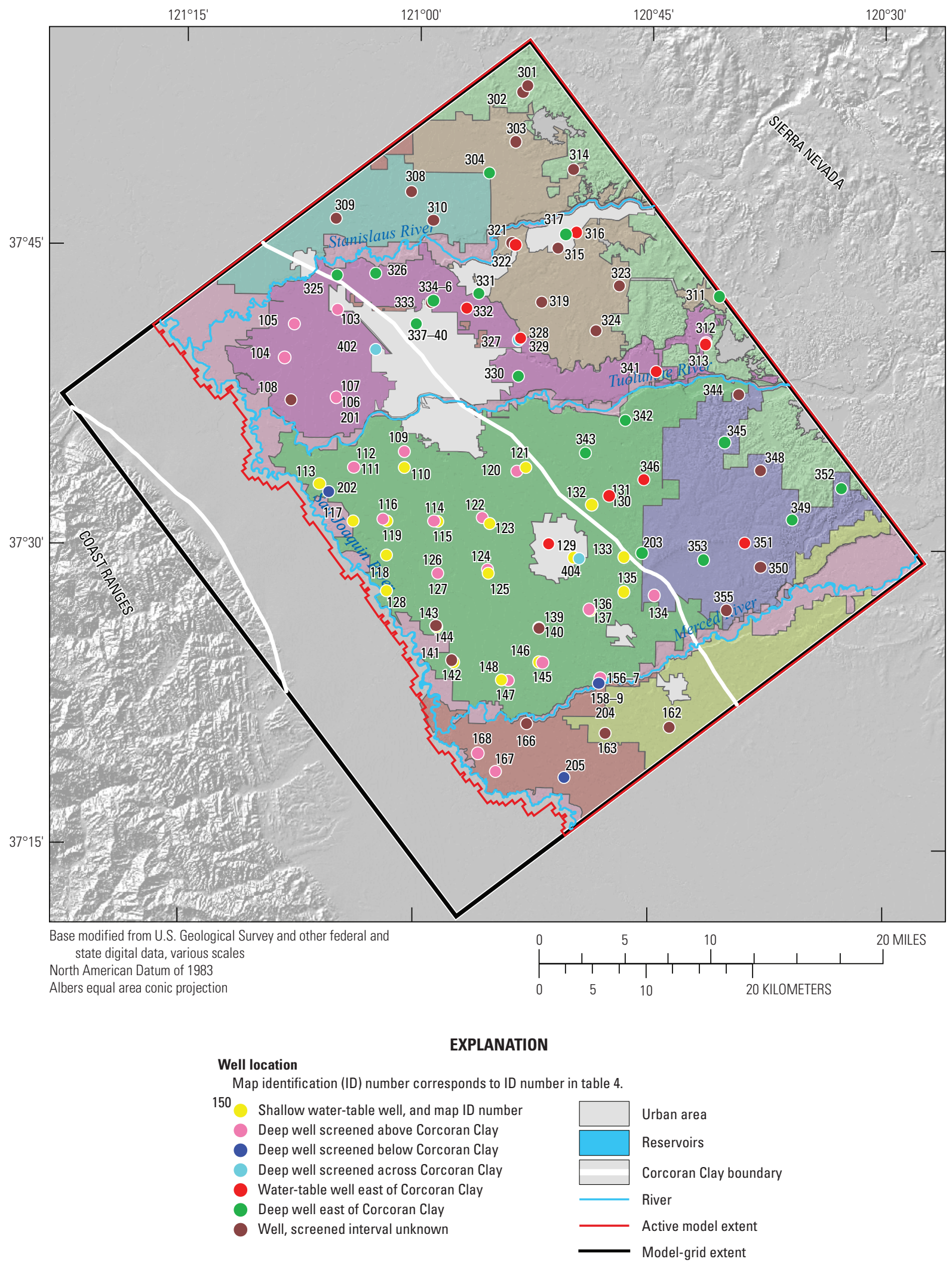

Figure 19. Locations of wells used to calibrate the MERSTAN model, Modesto region, California. Well construction and other information are shown in table 4. Background colors show agricultural, natural, and urban areas described in figure 7. 
Table 4. Monitored wells in the Modesto region, California, used to calibrate the MERSTAN model.

[Well locations shown on figure 6. Altitude datum: North American Vertical Datum of 1988 (NAVD 1988). Abbreviations: CC, Corcoran Clay; DWR, California Department of Water Resources; ft, feet; MER, Merced Irrigation District; MID, Modesto Irrigation District; OID, Oakdale Irrigation District; PLSS, Public Land Survey System; TID, Turlock Irrigation District; TID15ft, 15 -foot observation wells owned by TID; USGS, U.S. Geological Survey; -, other; 一, unknown]

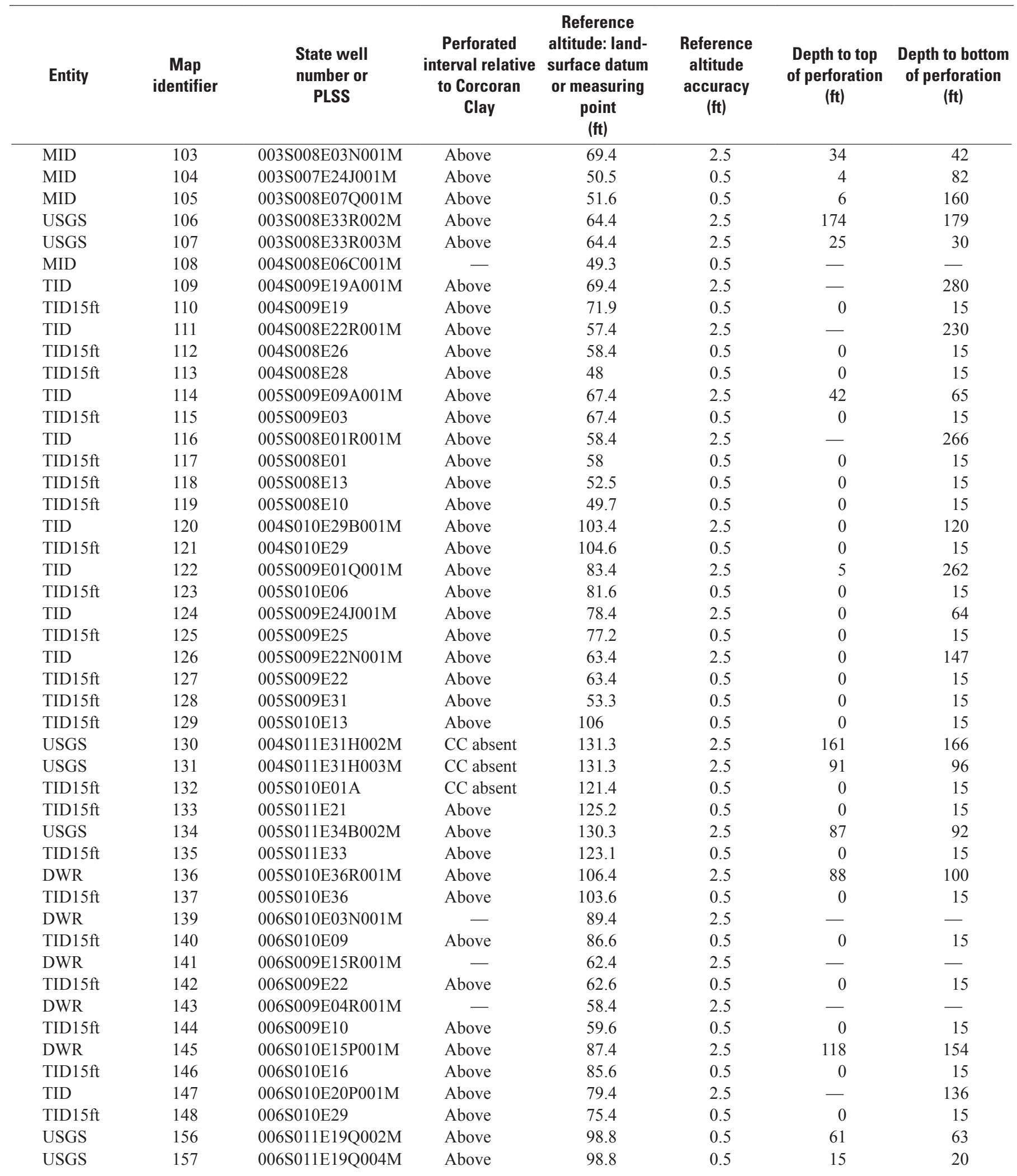


Table 4. Monitored wells in the Modesto region, California, used to calibrate the MERSTAN model.-Continued

[Well locations shown on figure 6. Altitude datum: North American Vertical Datum of 1988 (NAVD 1988). Abbreviations: CC, Corcoran Clay; DWR, California Department of Water Resources; ft, feet; MER, Merced Irrigation District; MID, Modesto Irrigation District; OID, Oakdale Irrigation District; PLSS, Public Land Survey System; TID, Turlock Irrigation District; TID15ft, 15-foot observation wells owned by TID; USGS, U.S. Geological Survey; -, other; -, unknown]

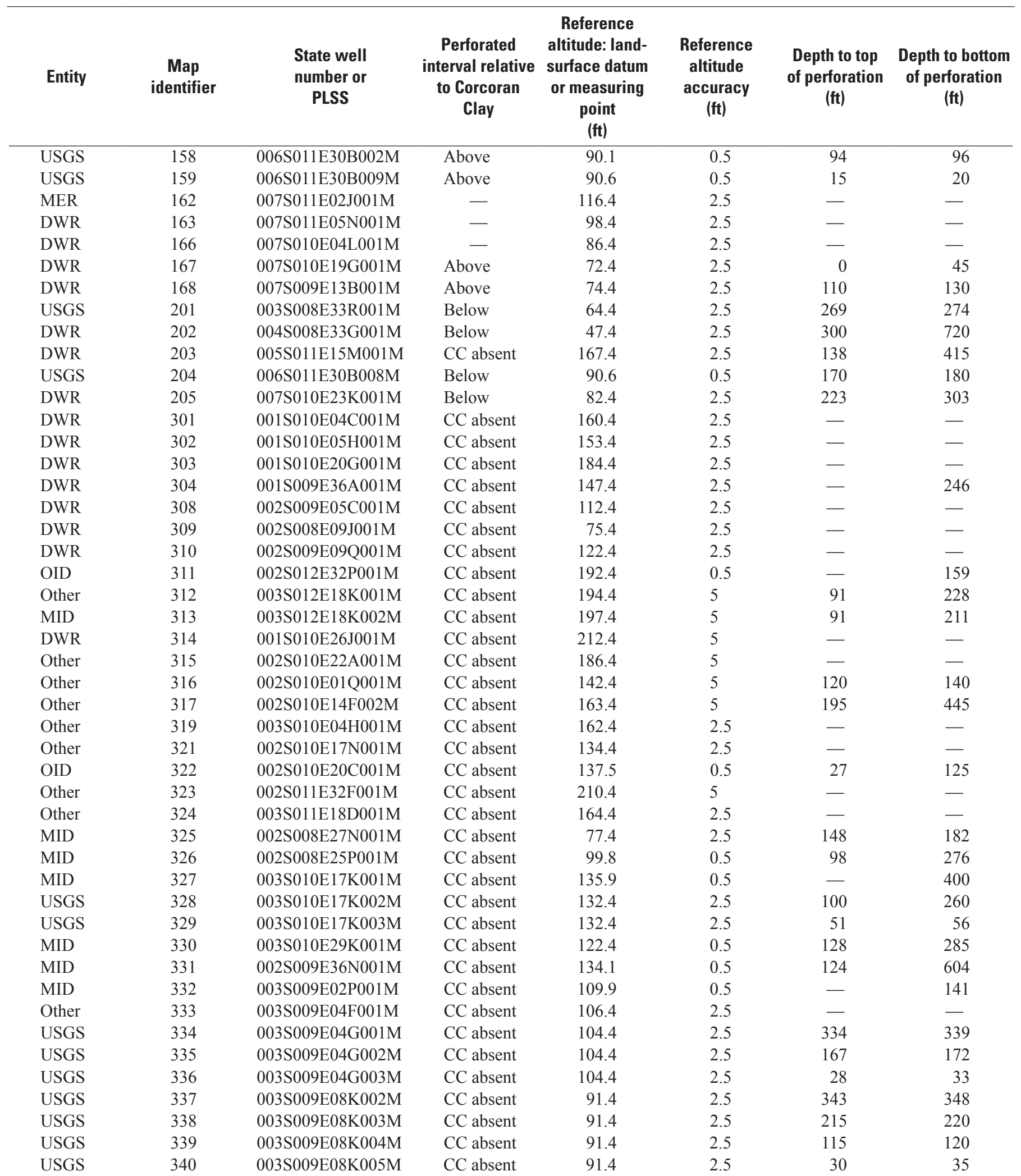


Table 4. Monitored wells in the Modesto region, California, used to calibrate the MERSTAN model.—Continued

[Well locations shown on figure 6. Altitude datum: North American Vertical Datum of 1988 (NAVD 1988). Abbreviations: CC, Corcoran Clay; DWR, California Department of Water Resources; ft, feet; MER, Merced Irrigation District; MID, Modesto Irrigation District; OID, Oakdale Irrigation District; PLSS, Public Land Survey System; TID, Turlock Irrigation District; TID15ft, 15-foot observation wells owned by TID; USGS, U.S. Geological Survey; -, other; -, unknown]

\begin{tabular}{|c|c|c|c|c|c|c|c|}
\hline Entity & $\begin{array}{c}\text { Map } \\
\text { identifier }\end{array}$ & $\begin{array}{c}\text { State well } \\
\text { number or } \\
\text { PLSS }\end{array}$ & $\begin{array}{c}\text { Perforated } \\
\text { interval relative } \\
\text { to Corcoran } \\
\text { Clay }\end{array}$ & $\begin{array}{c}\text { Reference } \\
\text { altitude: land- } \\
\text { surface datum } \\
\text { or measuring } \\
\text { point } \\
\text { (ft) }\end{array}$ & $\begin{array}{l}\text { Reference } \\
\text { altitude } \\
\text { accuracy } \\
\text { (ft) }\end{array}$ & $\begin{array}{c}\text { Depth to top } \\
\text { of perforation } \\
\text { (ft) }\end{array}$ & $\begin{array}{c}\text { Depth to bottom } \\
\text { of perforation } \\
\text { (ft) }\end{array}$ \\
\hline Other & 341 & 003S011E27G001M & CC absent & 182.4 & 2.5 & 110 & 200 \\
\hline DWR & 344 & 003S012E33L001M & CC absent & 202.4 & 2.5 & - & - \\
\hline DWR & 345 & 004S012E17G001M & CC absent & 232.4 & 2.5 & 176 & 360 \\
\hline Other & 346 & 004S011E28J001M & CC absent & 162.4 & 2.5 & 75 & 142 \\
\hline DWR & 348 & 004S012E27J001M & $\mathrm{CC}$ absent & 267.4 & 2.5 & - & - \\
\hline DWR & 349 & 005S012E01J001M & $\mathrm{CC}$ absent & 241.4 & 2.5 & 172 & 366 \\
\hline DWR & 350 & 005S012E22H001M & $\mathrm{CC}$ absent & 222.4 & 2.5 & - & - \\
\hline DWR & 355 & 005S012E33N001M & CC absent & 170.4 & 2.5 & - & - \\
\hline MID & 402 & 003S008E24C002M & Across & 76.6 & 0.5 & 152 & 364 \\
\hline TID & 404 & 005S010E24C001M & Across & 106.4 & 2.5 & - & 325 \\
\hline
\end{tabular}

\section{Parameters Estimated}

Estimation of all model parameters would be computationally expensive, requiring a separate model run for each parameter; it also is generally unnecessary. Many parameters associated with the Farm Process were identified as "known" on the basis of the source and quality of their measured or estimated values or their relative sensitivity determined during initial manual trial-and-error calibration runs. As part of the parameter estimation process, PEST determines the relative sensitivity of the parameters; those with very low sensitivities were not estimated, and retained their initial values.

PEST was used to estimate the values for 17 primary parameters, which included those related to aquifer hydraulic conductivity and storage properties, streambed hydraulic conductivities, and the external-head component of the western general-head boundary (table 5). The aquifer-system hydraulic conductivities, specific storages, and the streambed hydraulic conductivities were log-transformed so that model results varied more linearly with changes in parameter values. There were 16 additional parameters associated with the external-head component of the western general-head boundary; these were tied to a single estimated parameter (ghb_elev1; table 5), such that the 16 additional parameter values spaced along the western general-head boundary were adjusted from their initial values during calibration by the same amount as the single general-head boundary parameter estimated.

\section{Observation Weights}

It was noted previously that each residual between a simulated and observed value was multiplied by a userassigned weight. There are several reasons for weighting residuals, including (1) observation types can have very different magnitudes of residuals, which can result in a high effective weight for one observation type over another; (2) some locations have many more observations than others, resulting in a high effective weight for those locations; and (3) some observed locations can have greater importance than others for model calibration. These three categories of weights, described in detail in this section, were multiplied together, resulting in a composite weight for each observation.

Groundwater altitudes and streamflow observations, which were used for the PEST calibration of the MERSTAN model, often differed by several orders of magnitude. A small residual in streamflow, expressed as cubic foot per day $\left(\mathrm{ft}^{3} / \mathrm{d}\right)$, would be very large compared to a small residual in groundwater altitude, expressed in ft. In seeking to minimize 
Table 5. Parameters estimated for the MERSTAN model, Modesto region, California.

[Abbreviations: ft, foot; ft/d, foot per day; per ft, per foot; QPC, Quaternary Plio-Pleistocene age semi-consolidated]

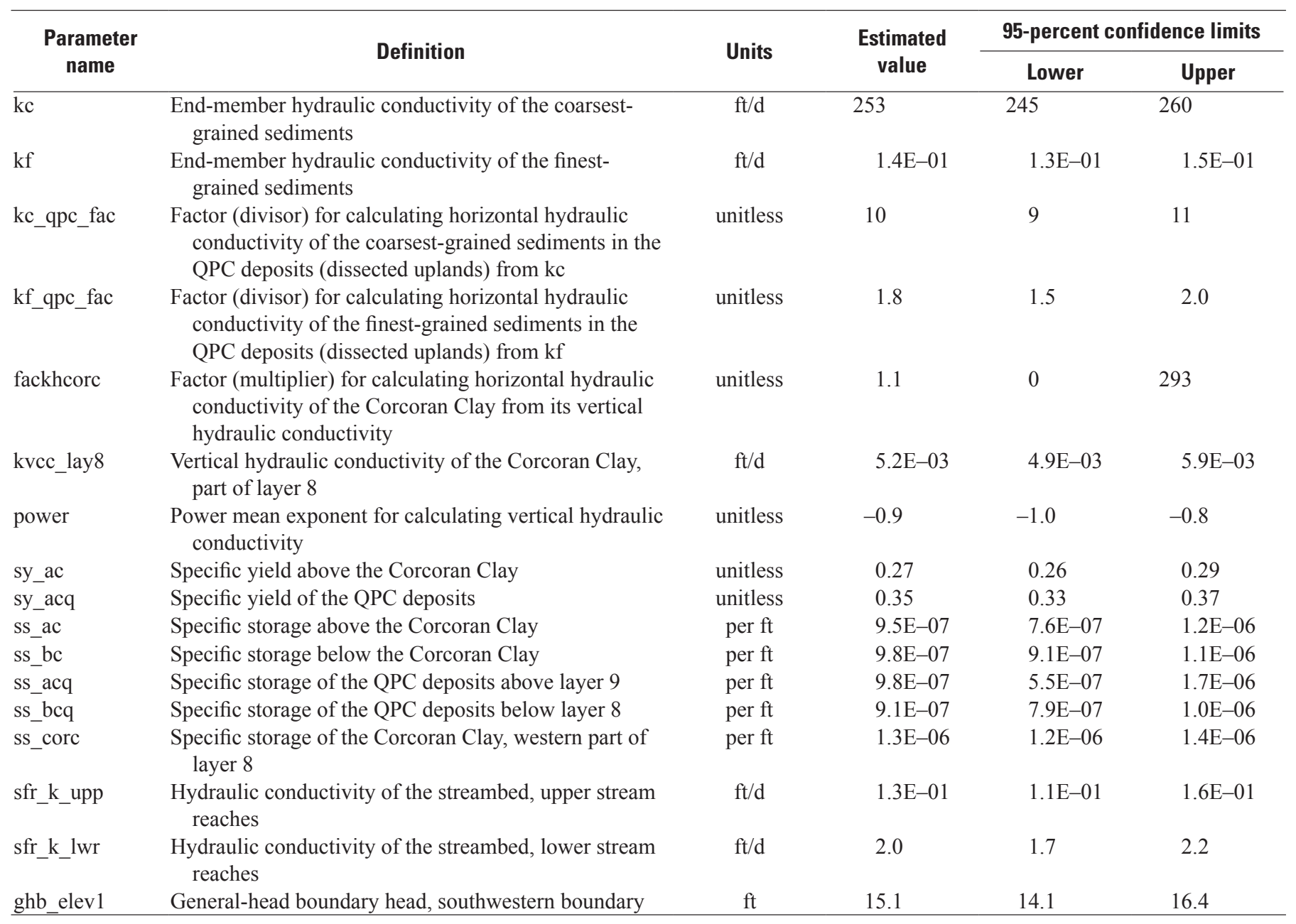

the sum of squared residuals, therefore, PEST focuses primarily on matching streamflow because groundwater altitude is of minor importance to the solution. To address this, all streamflow residuals were weighted such that they represented a percentage of change in streamflow rather than an absolute change. The weights were assigned such that a 100-percent residual in streamflow was the equivalent of a 100-ft residual in groundwater altitude. For streamflow observations below 500 cubic feet per second $\left(\mathrm{ft}^{3} / \mathrm{s}\right)$, it was assumed the flow was $500 \mathrm{ft}^{3} / \mathrm{s}$ for the purpose of calculating the weight. For example, if the observed flow was $0 \mathrm{ft}^{3} / \mathrm{s}$, and the simulated flow was $250 \mathrm{ft}^{3} / \mathrm{s}$, the weighted residual would be 50 percent (equivalent of $50 \mathrm{ft}$ ).

The number of observations varied greatly among wells and streamgages. To prevent sites with many observations from dominating the calibration process, each observation at a site was given a weight of the square root of the reciprocal of the number of observations at that site; thus, those sites with fewer observations were given additional weight, resulting in spatial consistency.

Two sets of wells were considered to be relatively important to model calibration. One of these sets was wells installed and measured by the USGS, all of which were multi-depth monitoring wells, which provide data on vertical hydraulic gradients. Observations for these were assigned a weight of 1.73. The other set of wells was a subset of the network of shallow (15-ft deep) wells installed and monitored on a monthly basis by the Turlock Irrigation District. These high-frequency measurements of the water table are valuable for calibration of the position and seasonal variability of much of the area underlain by a shallow water table. Observations for these were assigned a weight of 1.41. All other calibration wells (table 4) were assigned a weight of 1. 


\section{Calibration Results}

\section{Simulated Heads}

A series of graphs showing overall model fit between simulated heads and measured water levels is shown in figure 20. Figure $20 \mathrm{~A}$ is a 1-to-1 plot, where equal simulated and measured values would fall on the diagonal 1:1 line. Points plotting below the 1:1 line indicate simulated heads lower than measured; the opposite is indicated for points plotting above the 1:1 line. There are 4,061 points on the plot, representing that many water-level measurements from 109 wells in the model area (fig. 19, table 4), all of which were used as observations in the model calibration process. Notably, measured water levels associated with short-screened wells (labeled USGS and "Turlock ID 15ft") generally were wellsimulated and clustered near the 1:1 line. Overall, 74 percent of simulated heads were within $10 \mathrm{ft}$ of measured water levels, 89 percent were within $20 \mathrm{ft}$, and 98 percent were within $30 \mathrm{ft}$. The 2 percent of simulated heads that had error exceeding $30 \mathrm{ft}$ were primarily associated with wells near the eastern boundary of the model (fig. 19).

Figure $20 B$ shows the residuals (simulated head minus observed) compared to the overall range of observed heads. If all observations were simulated exactly, all points would be on the zero-residual line. This graph shows that the residuals generally were centered about the zero-residuals line, indicating low bias and roughly equal spatial distribution of error for most locations. The primary exception was a negative bias in areas where observed heads were highestthat is, simulated heads were too low in these areas. The observations in these areas were mostly associated with the northeasternmost wells (fig. 19) near the northeastern no-flow boundary.

A histogram of the residuals (fig. 20C) indicated that the residuals were normally distributed, which meant that the bias toward positive or negative residuals was low. The residuals ranged from about -60 to $45 \mathrm{ft}$, had a mean of $-2.1 \mathrm{ft}$, an absolute mean of $0.8 \mathrm{ft}$, a standard deviation of $11.7 \mathrm{ft}$, and a skewness of -0.83 . The mean value of $-2.1 \mathrm{ft}$ and skewness value indicated an overall bias toward underestimation of simulated heads, and the absolute mean of $0.8 \mathrm{ft}$ indicated good overall model fit for a region of this scale.

Hydrographs of measured water levels and simulated hydraulic heads in the cell representing the midpoint of the screened interval of the well best are shown for all calibration wells in the model area in figure 21. The locations of these wells are shown in figure 19, and construction details are shown in table 4 . These wells are referred to by their map number in this report (fig. 19, table 4).

Measured water levels and simulated heads generally compared well for wells in the Modesto Irrigation District and the city of Modesto (fig. 21). Most of the hydrographs showed a reasonable match between simulated and observed trends and variability. Well 105 showed simulated variability greater than observed, but the overall trend was reasonably simulated. The hydrograph for well 330 showed simulated heads about 15-20 ft higher than observed, and well 312, near the northeastern boundary, showed the opposite.

The hydrograph for well 331, which is near the southern boundary of the city of Riverbank, shows that the overall observed trend, seasonal variability, and magnitude were reasonably simulated for this well.

In Oakdale Irrigation District and the city of Oakdale, simulated heads generally compared well to observed (fig. 21). The observed trends and variability generally were simulated well. South of the Stanislaus River, and for well DWR314 north of the river, simulated heads reasonably matched the magnitude of observed. An exception was well 311, next to the northeastern boundary, which showed a long-term downward trend not evident in the measured data.

Simulated water levels for wells 301 and 302, in the foothills area near the northeastern corner of the model, were less than measured by about $30 \mathrm{ft}$. This location was heavily influenced by the heads specified along the northwestern general-head boundary, which might be set too low at its eastern extent. Additional recharge from leakage of nearby (upgradient) Woodward Reservoir and through the modeled no-flow northeastern boundary could also be indicated. Downslope from this area, in the South San Joaquin Irrigation District, simulated heads compared well to measured water levels in all respects.

Measured water levels in the Turlock Irrigation District generally were well simulated; model results reasonably matched observed trends, magnitudes, and variability (fig. 21). Simulated heads representing wells in a network of 15 -ft wells installed and measured monthly by the Turlock ID generally showed a good match (note the narrower range on the $\mathrm{Y}$ axis on fig. 21) to measured water levels, including seasonal variability. Water levels from wells in the city of Turlock were reasonably simulated, as evidenced by wells 129 and 404 (fig. 21). 

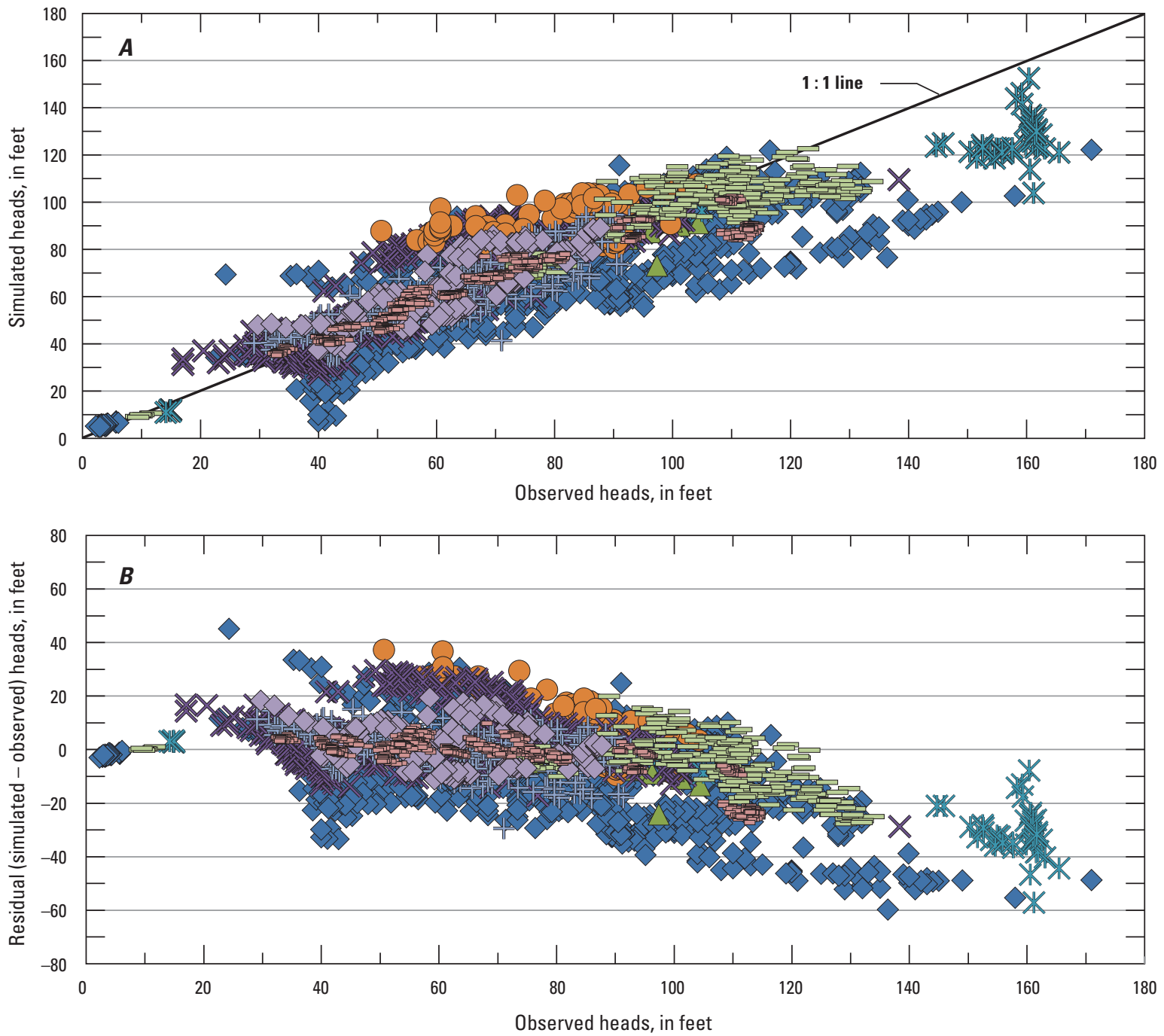

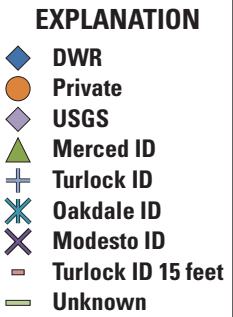

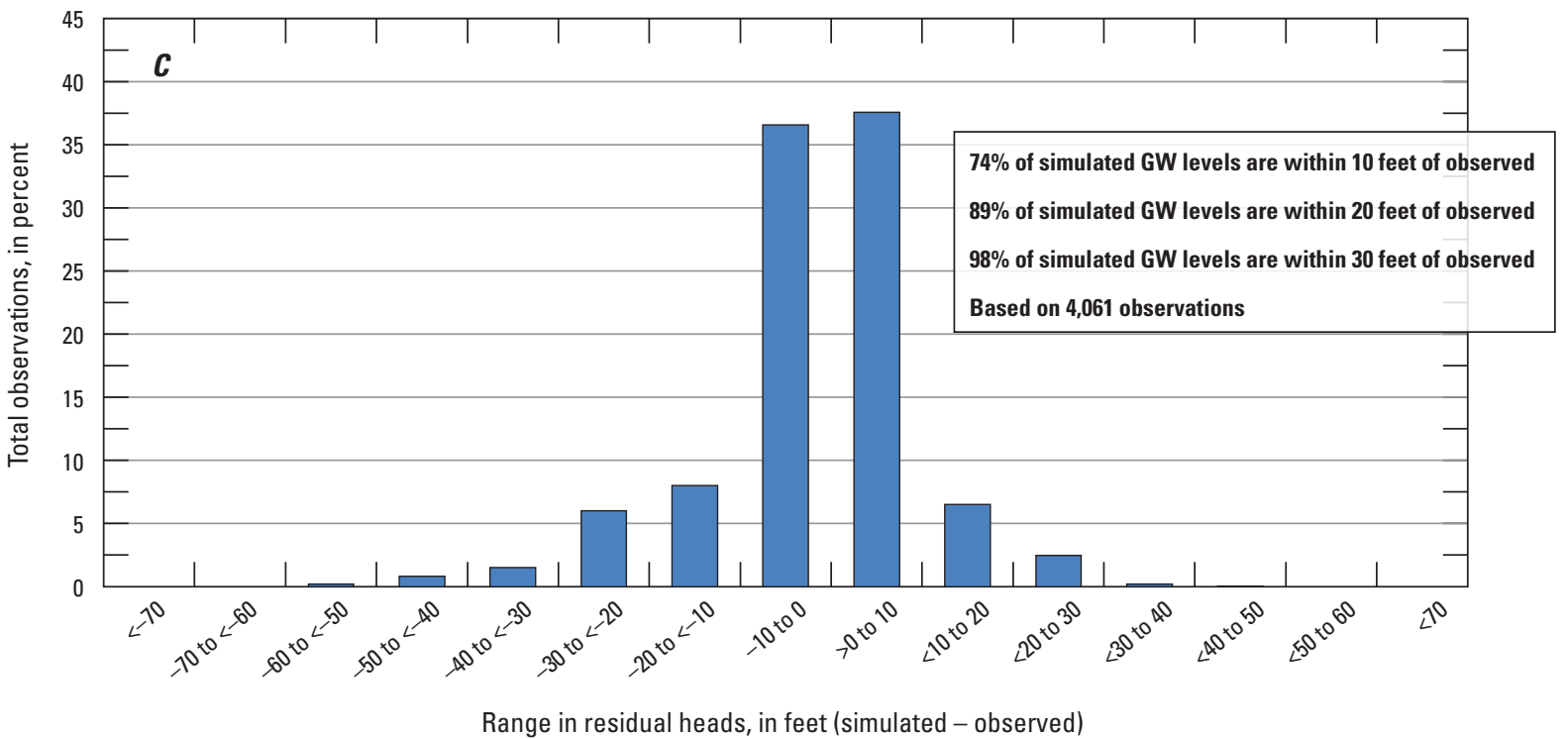

Figure 20. Heads for the MERSTAN model, Modesto Region, California: $A$, simulated and observed; $B$, residual (simulated - observed) and observed; and $C$, a histogram of residuals. Groundwater, GW; irrigation district, ID; Department of Water Resources, DWR; United States Geological Survey, USGS. 
Figure 21. Measured water levels for all wells used to calibrate the MERSTAN model, Modesto region, California, and simulated heads in the model cells most representative of each well. Wells are referred to by map identification (ID), as shown in figure 19, and wellconstruction information is shown in table 4. (Figure is provided as a downloadable Microsoft Excel ${ }^{\circledR}$ file.)

A region in the Turlock ID that was not simulated well is that near the boundary between the Turlock ID and Eastside Water District, east of the city of Turlock (fig. 7). There was a large difference in measured water levels in shallow wells (for example, wells 132, 133 in fig. 21) and deep wells in this region, which were removed from the calibration data set; simulated heads in the shallow wells were substantially lower than measured, and those in deeper parts of the aquifer system in this area were substantially higher than measured. The low water levels in the deeper wells were likely associated with the cone of depression from groundwater pumping in Eastside Water District, which does not have access to surface-water resources, along with pumping wells associated with the city of Turlock and in the Turlock ID. Relatively high water levels near the land surface in Turlock ID were likely fed by deep percolation from flood irrigation and precipitation. Between the shallow and deeper zones, it is possible the aquifer had been dewatered, resulting in a shallow perched aquifer overlying a much deeper water table; perched conditions were speculated as a possible explanation for the large differences in measured water levels. Another possible explanation is a concentration of pumping in the area that had large water-level differences. The actual distribution of pumping is unknown and, in the MERSTAN model, was assumed to be evenly distributed. During calibration, this large vertical hydraulic gradient was not well-simulated when using reasonable values for hydraulic parameters and the assumed even distribution of irrigation pumpage; the version of MODFLOW used for this study did not, while this study was underway, support the simulation of perched conditions.

Simulated heads for wells in and near Eastside Water District reasonably matched observed trends and seasonal variability, but often were higher or lower than observed heads (fig. 21). This was partly due to the existence of a cone of depression associated with groundwater pumping in the Eastside WD and the associated relatively steep, lateral hydraulic gradients. It could also be partly due to the inability of the model to simulate the large observed vertical hydraulic gradients east of the city of Turlock. A potential consequence of this inability is that the simulated center of the cone of depression was east of the observed location (discussed in the "Map of Simulated Water-Table Elevation" section of this report), which resulted in underestimation of simulated heads east of the observed center of the cone (for example, well 348 in fig. 21). The no-flow nature of the northeastern boundary condition could also be a factor in the simulated position of the cone of depression, as indicated by the much lower (by about $50 \mathrm{ft}$ ) simulated water levels compared to observed levels in well 352 , which is about $1.5 \mathrm{mi}$ from the model boundary.

In the vicinity of Merced Irrigation District, in the southern part of the model area, simulated heads reasonably matched most of the magnitude and variability in the observed water levels (fig. 21). The simulated head for well 163 was less than observed by about 10-15 ft, and the simulated trend did not match the observed.

\section{Simulated Streamflow}

The overall model fit between simulated monthly and mean monthly observed streamflow is shown in figure $22 A-C$. Figure $22 A$ is a 1 -to- 1 plot, where equal simulated and observed values for the six gaging stations fall on the 1:1 line. Points plotting below the 1:1 line indicate simulated streamflow was lower than observed; the opposite is indicated for points plotting above the 1:1 line. There are 2,739 points on the plot, representing mean monthly streamflow measurements in the model area; these were used as observations in the model calibration process. Three streamgages were on the San Joaquin River, and there was one streamgage each on the Stanislaus, Tuolumne, and Merced Rivers (fig. 1). Overall, 68 percent of simulated streamflow was within $500 \mathrm{cfs}$ of measured, and 82 percent was within 1,000 cfs. A low bias for relatively low streamflow, particularly on the Stanislaus River, is apparent on the 1:1 plot.

Figure $22 B$ shows the residuals, or difference between simulated and measured streamflow, compared with the overall range of measured values. If all measurements were simulated exactly, all points would plot on the zero-residuals line. This graph shows that the residuals generally were spread across the zero-residuals line for low- to mid-range flows, but a low bias was evident for the highest streamflows.

A histogram of the residuals (fig. 22C) showed that the distribution was not normal, with a negative skew, indicating the negative bias (underestimation of observed streamflow) noted previously. The residuals ranged from about $-11,600 \mathrm{cfs}$ to $10,300 \mathrm{cfs}$, had a mean of $-248 \mathrm{cfs}$, an absolute mean of $780 \mathrm{cfs}$, a standard deviation of $1,230 \mathrm{cfs}$, and a skewness of -1.7 . The mean value of $-248 \mathrm{cfs}$ and the skewness indicated bias toward low estimation by simulated streamflow, and the absolute mean of $780 \mathrm{cfs}$ indicated a reasonable model fit for a region of this scale. 

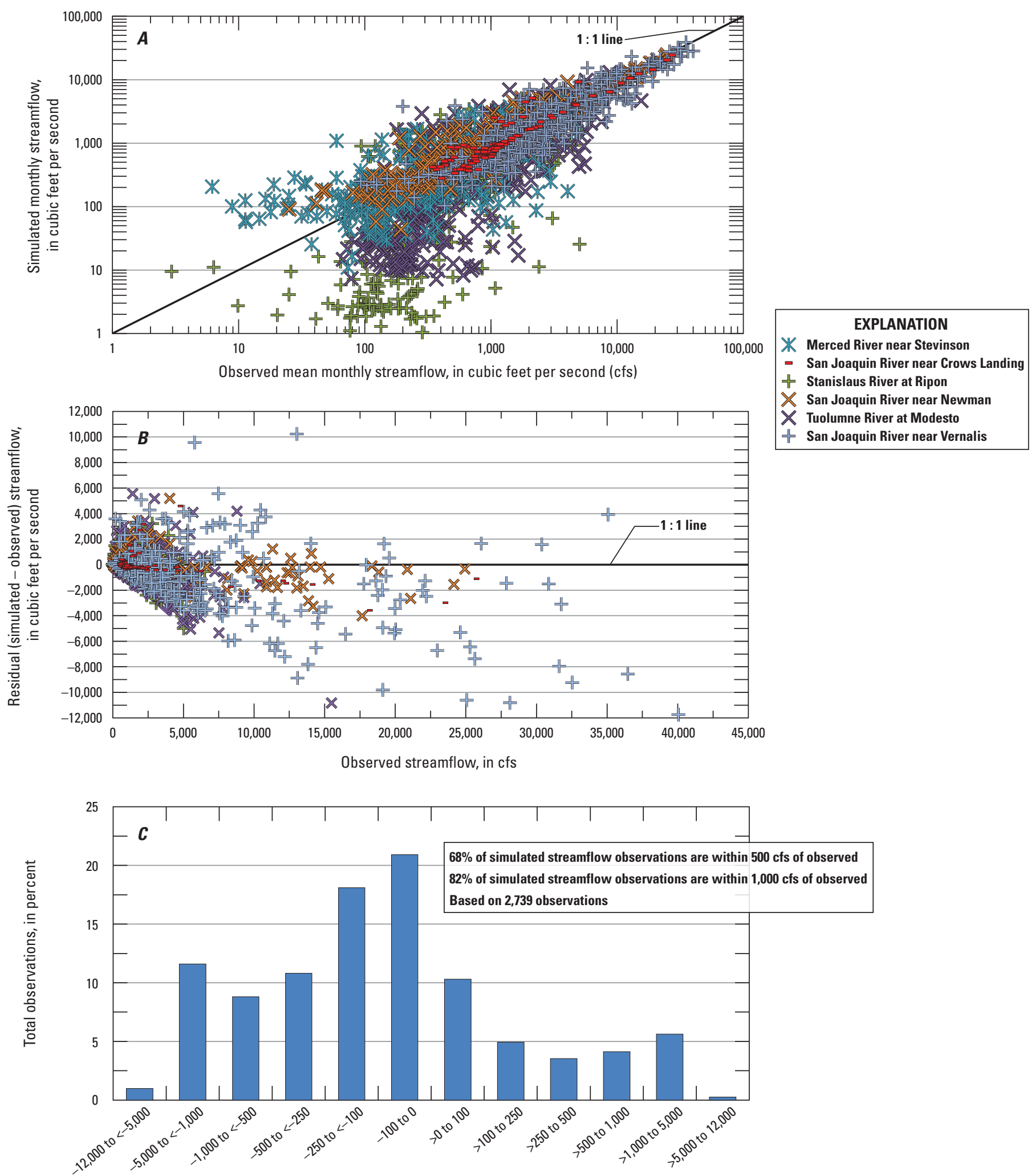

Range in residual (simulated - observed) streamflow, in cfs

Figure 22. Comparisons of observed and simulated streamflow from the MERSTAN model, Modesto region, California, 1960-2004: $A$, simulated versus observed streamflow; $B$, residual (simulated - observed) versus observed streamflow; and $C$, a histogram of residual streamflow. 
Observed and simulated stream stage and streamflow are shown in figure 23 for the six streamgages used for model calibration. Stream stage was not used in the PEST calibration, but was adjusted by lowering the estimated streambed elevation, initially set to stream stage on the basis of USGS topographic maps, to achieve a reasonable match between simulated and measured monthly average stage. The relation between simulated stream stage and the groundwater head below the river determines whether the stream is gaining or losing and the rate of that gain or loss. Stream stage at five of the six streamgages showed a good match between observed and simulated stage (fig. 23). Matching stage was not achieved at the Merced River streamgage; simulated stage generally was a few feet higher than the observed stage at this location.

The overall match to streamflow was reasonable (fig. 23), although the highest streamflows on the San Joaquin River near Vernalis were notably lower than observed and accounted for much of the underestimation by the model shown in figure 22. The same streamflow information is plotted on a log scale in figure 24, which makes it easier to compare observed and simulated streamflow at low-flow rates. Low streamflow generally was simulated reasonably well at most locations, with two exceptions: the Tuolumne River at Modesto and the Stanislaus River at Ripon. In both cases, simulated streamflow estimated observed values better during the latter part of the simulation period.

\section{Correlation Coefficient}

The correlation coefficient $(\mathrm{R})$ is a measure of strength of the linear relation between two variables. An $R$ value of 0 indicates that there is no linear association between the two variables, whereas an $\mathrm{R}$ values of 1 or -1 indicates a strong linear association. $\mathrm{R}$ is defined as follows (Cooley and Naff, 1990):

$$
R=\frac{\sum_{m}\left(w_{m} \times h_{m}^{o b s}-\bar{h}^{o b s}\right) \times\left(w_{m} \times h_{m}^{s i m}-\bar{h}^{\text {sim }}\right)}{\sqrt{\sum_{m}\left(w_{m} \times h_{m}^{o b s}-\bar{h}^{o b s}\right)^{2} \times \sum_{m}\left(w_{m} \times h_{m}^{s i m}-\bar{h}^{\text {sim }}\right)^{2}}}
$$

where

\begin{tabular}{|c|c|}
\hline $\begin{array}{r}R \\
h_{m}^{o b s}\end{array}$ & $\begin{array}{l}\text { is the correlation coefficient, } \\
\text { is the value of observation } m \text {, }\end{array}$ \\
\hline $\bar{h}^{o b s}$ & is the mean of the weighted observed values, \\
\hline$h_{m}^{s i m}$ & $\begin{array}{l}\text { is the simulated value corresponding to } \\
\text { observation } m \text {, }\end{array}$ \\
\hline $\bar{h}^{s i m}$ & $\begin{array}{l}\text { is the mean of the weighted simulated values, } \\
\text { and }\end{array}$ \\
\hline $\mathcal{w}_{m}$ & is the weight of the $m^{\text {th }}$ observation. \\
\hline
\end{tabular}

A value of $\mathrm{R}$ greater than 0.9 generally indicates a strong linear association between the simulated and observed values (Hill and Tiedeman, 2007). The R for the 4,061 groundwater elevations for the MERSTAN model was 0.90 and was 0.94 for the 2,739 monthly streamflow values. Note that the simulated values for streamflow were largely governed by specified inflows at the upstream model boundaries; therefore, the correlation coefficient could be considered a less meaningful indicator of model fit with respect to streamflow than with respect to head.

\section{Discussion of Parameter Estimates}

Some of the calibrated parameter values can be compared, to a degree, to values from previous studies, including the steady-state model for water year 2000 (Phillips and others, 2007) and several studies that derived estimates from field measurements. The same sedimenttexture distribution used in the steady-state model was used in the MERSTAN model; thus, the distribution of hydraulic properties did not change from that model; however, inclusion of new data, changes in the way agricultural and streamflow processes were simulated, and transient calibration resulted in changes in the magnitudes of the hydraulic properties.

Single-well hydraulic tests, commonly known as slug tests, were done in 18 shallow monitoring wells in the bed and on the banks of the Merced River west of highway 99 (Zamora, 2006). The sediments tested ranged from silty sand to well-sorted coarse sand, and computed hydraulic conductivity values ranged from 50 to 820 feet per day (ft/d); the mean and median values were 280 and $240 \mathrm{ft} / \mathrm{d}$, respectively. These field-based results agreed well with the calibrated, coarse-grained end-member hydraulic conductivity of about $250 \mathrm{ft} / \mathrm{d}$ (table 5). This calibrated value also was consistent with the equivalent calibrated value $(260 \mathrm{ft} / \mathrm{d})$ from the steady-state model of water-year 2000 (Phillips and others, 2007).

There were no field-based estimates available for the hydraulic conductivity of distributed (not associated with the Corcoran Clay) fine-grained materials. The calibrated, finegrained end-member hydraulic conductivity from the steadystate model of water-year 2000 (Phillips and others, 2007) was $2.6 \times 10^{-2} \mathrm{ft} / \mathrm{d}$; the calibrated value for the MERSTAN model (table 5) was about a factor of 5 greater $\left(1.4 \times 10^{-1} \mathrm{ft} / \mathrm{d}\right)$. 

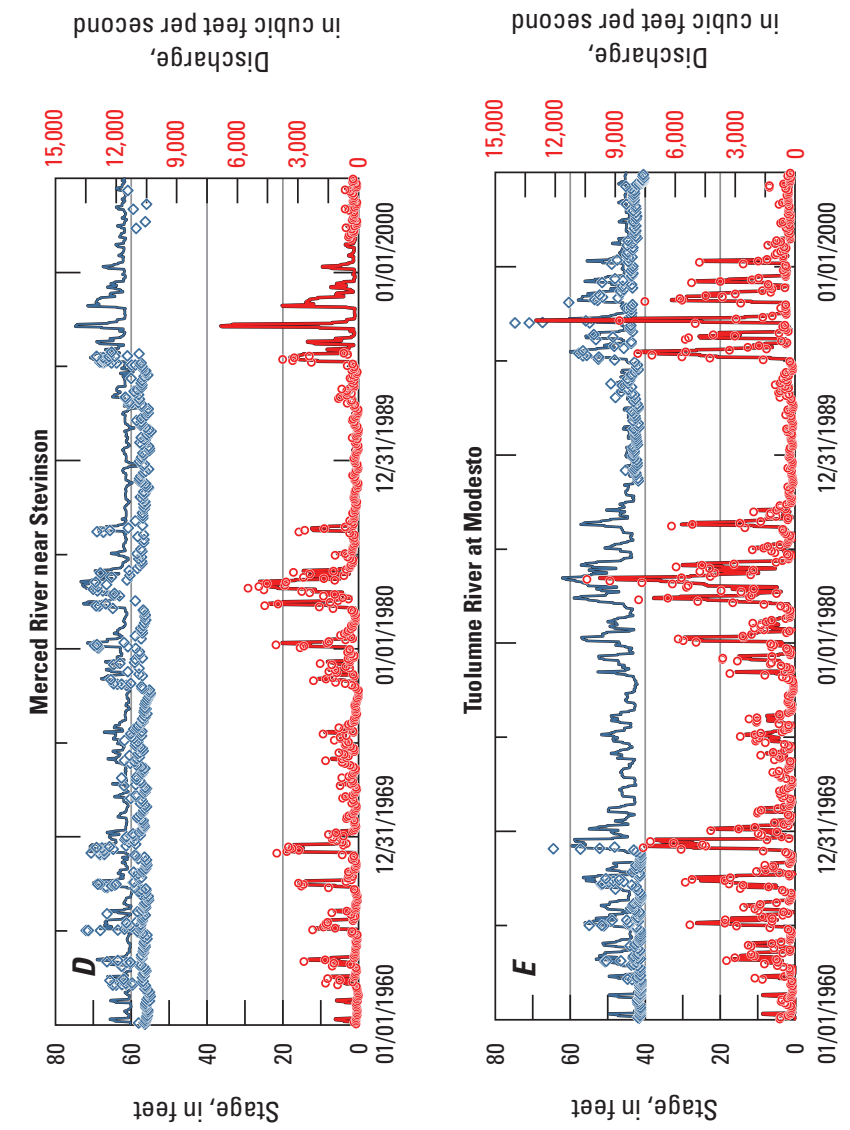
puoวəs ıəd łəəf ग!qno u! ‘әблечэง!0
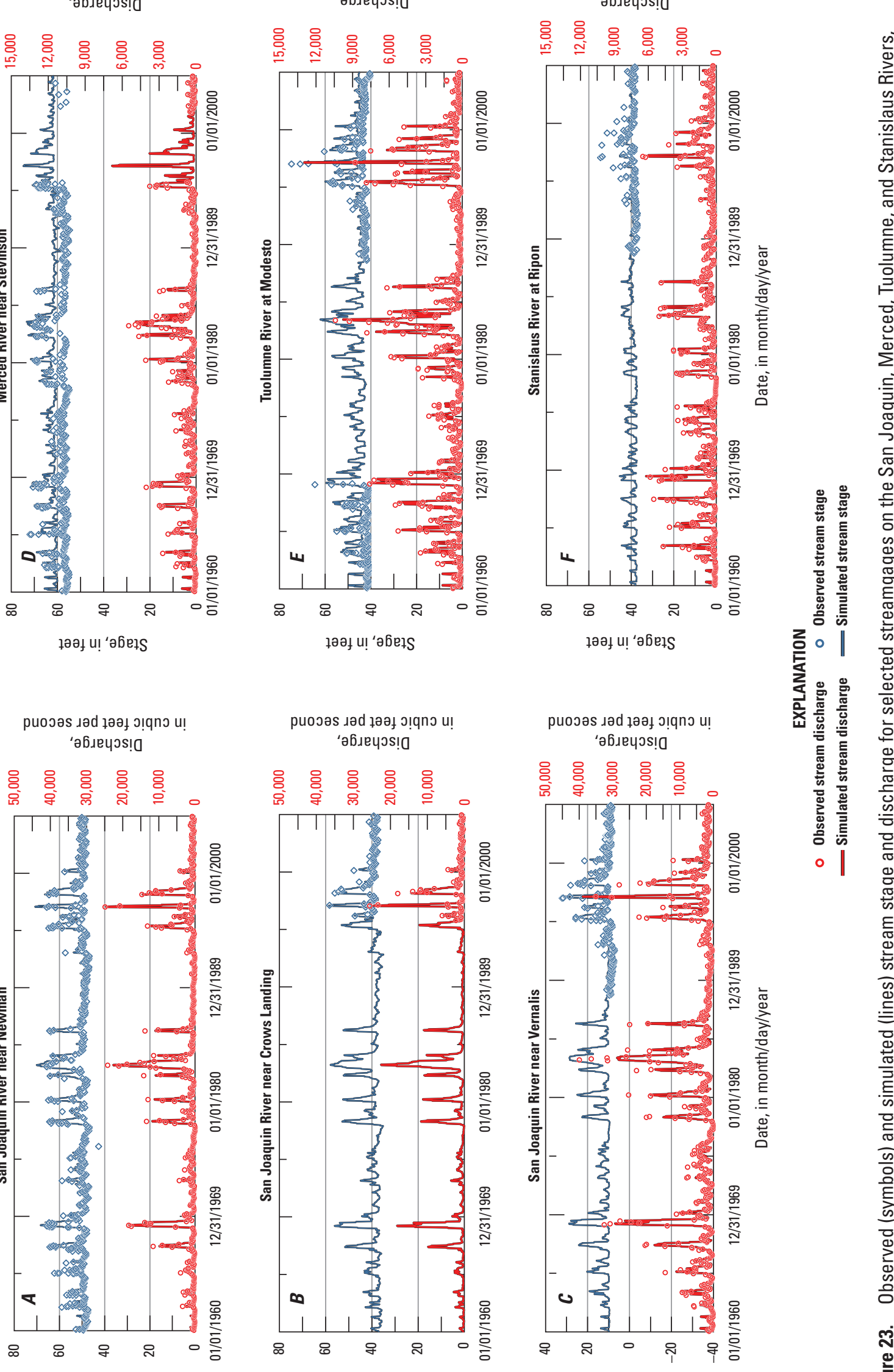

之。|

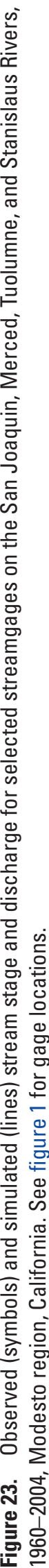

วәәر แ! ‘ว6อาร

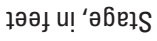

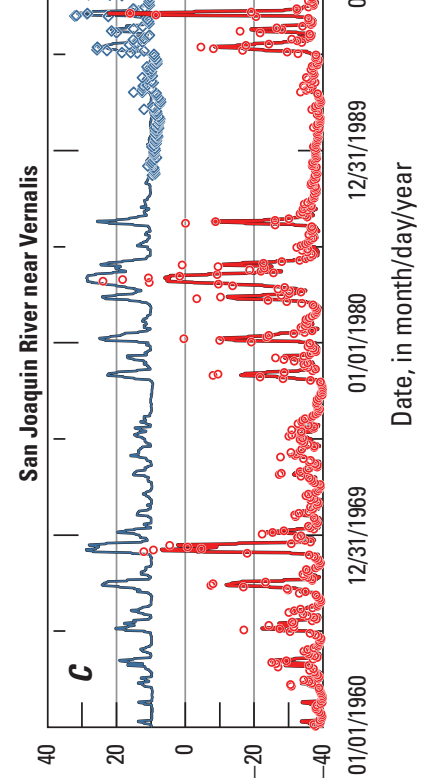

เәәу น! ‘әбетs 


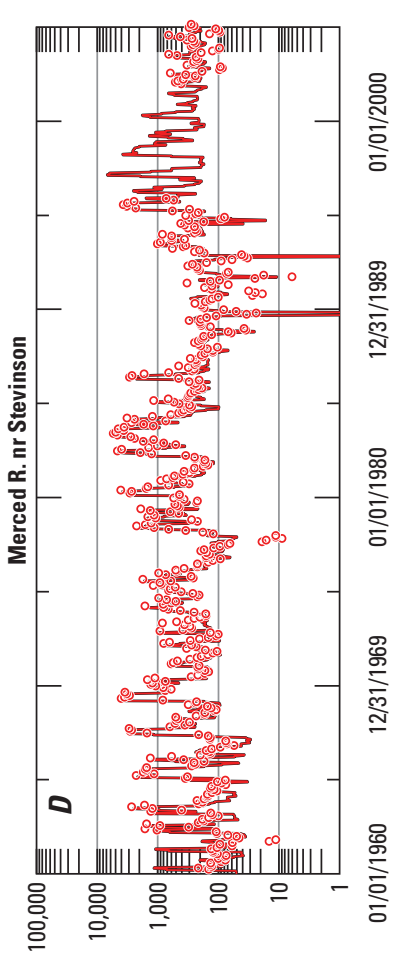

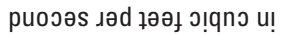
‘әблечวง!

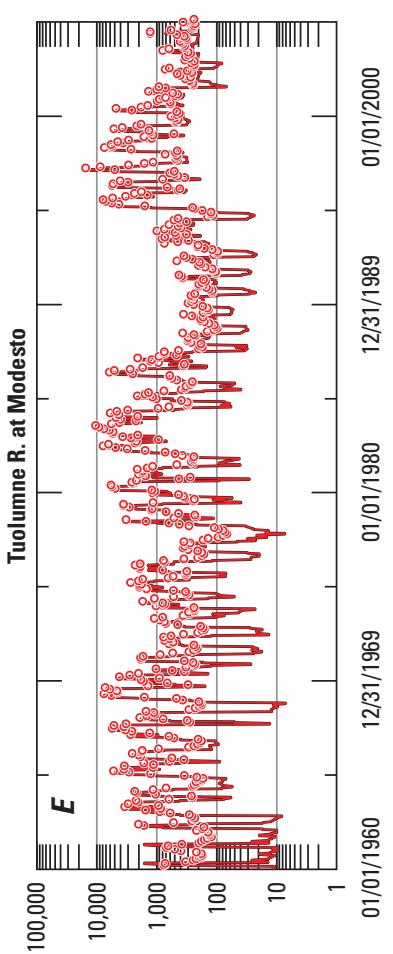

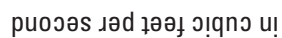
‘әблечэง!

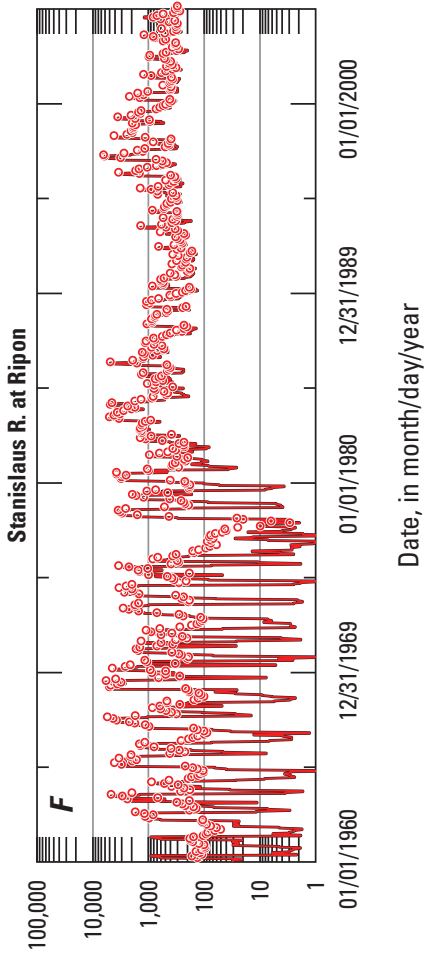

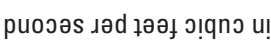
‘әблецэง!ด

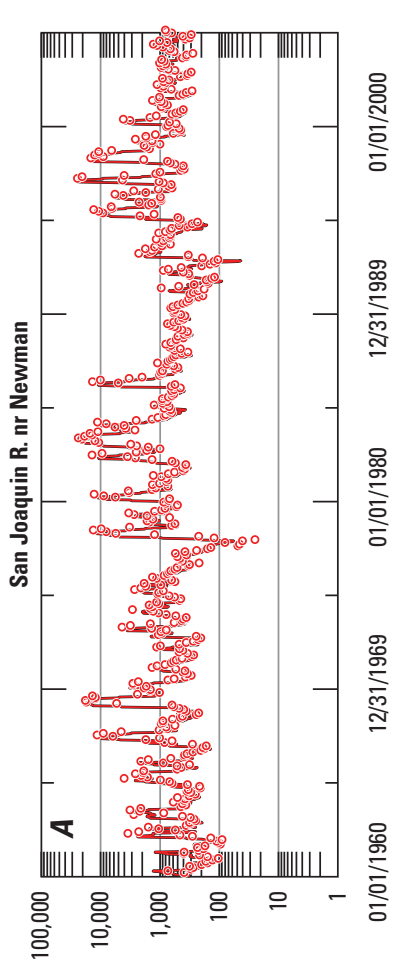

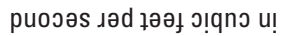
‘әбцецวง!

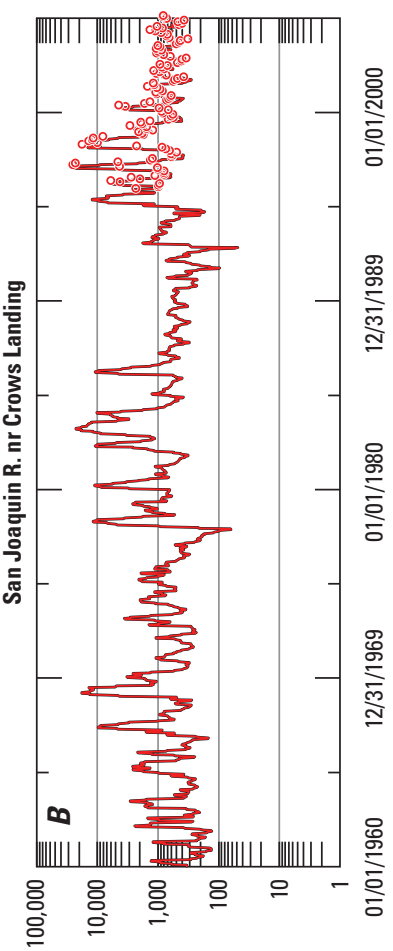

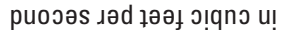
‘әбцечэง!

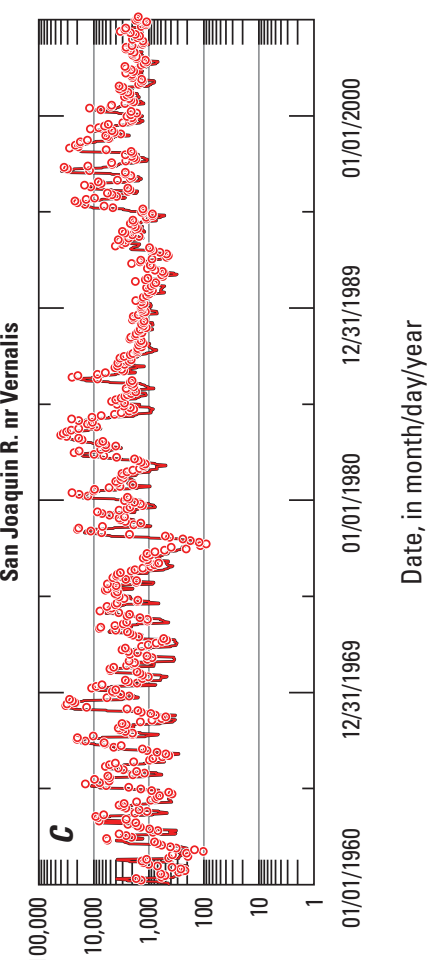

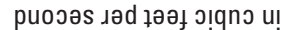
‘ә6цечэร!
年 ○

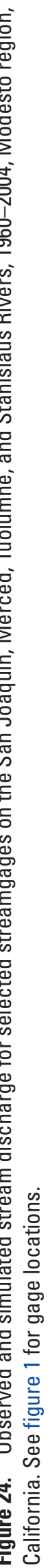


Permeameter tests of cores from the Corcoran Clay indicated vertical hydraulic conductivities ranging from $3 \times 10^{-6}$ to $1 \times 10^{-5} \mathrm{ft} / \mathrm{d}$ (Johnson and others, 1968). Previous regional modeling efforts (Williamson and others, 1989; Belitz and Phillips, 1995; Faunt, 2009), however, indicated that numerous wells screened across the Corcoran Clay locally short-circuited the impedance to vertical flow through the clay layer and significantly enhanced intra-borehole flow through the clay; the net result was higher estimates for the effective vertical hydraulic conductivity of the Corcoran Clay. The vertical hydraulic conductivity estimated by Belitz and Phillips (1995) for an area southwest of the regional model, where the Corcoran Clay is about 330-800 ft below land surface, was $5 \times 10^{-4} \mathrm{ft} / \mathrm{d}$. The calibrated, vertical hydraulic conductivity of the Corcoran Clay from the steady-state model was $4.3 \times 10^{-3} \mathrm{ft} / \mathrm{d}$, which compares well with $5.2 \times 10^{-3} \mathrm{ft} / \mathrm{d}$ for the MERSTAN model (table 5) and with $5 \times 10^{-4} \mathrm{ft} / \mathrm{d}$ (described previously) estimated where the Corcoran Clay is buried more deeply (Belitz and Phillips, 1995).

The calibrated exponent of the power mean for the MERSTAN model, which is used to calculate vertical hydraulic conductivity, was -0.9 . This value closely corresponded to the harmonic mean (power mean of -1.0), which was found to provide the best solution in previous modeling studies in this region (Phillips and Belitz, 1991; Phillips and others, 2007).

\section{Sensitivity Analysis and Parameter Uncertainty}

The final calibrated parameters are those that minimize the residuals between simulated and observed values given the constraints of prior information provided for some parameters. As with any model, small or large variations in multiple parameters can result in solutions of nearly the same errorthe calibrated parameter values are non-unique. Sensitivity testing and uncertainty analysis are, therefore, important steps in judging model performance (Hill \& Tiedeman, 2007).

A sensitivity analysis indicates the relative sensitivity of the solution to changes in the model parameters. There are important limitations associated with the sensitivity analysis presented here, including the assumption that the model solution varied linearly with adjustments to parameter values. The MERSTAN model includes head-dependent processes that would violate, to some degree, this assumption of linearity. The sensitivity analysis presented here also is limited to the simulated values for observations used for model calibration; there were no direct observations for groundwater recharge spatially or locally at streams for the MERSTAN model, for example; thus, the scope of the analysis was somewhat limited by the available data.
Values that were log-transformed for the calibration were not transformed for this analysis.

\section{Composite Sensitivity}

The composite sensitivity of a model parameter is defined as follows (Watermark Numerical Computing, 2005):

$$
S_{n}=\frac{\sqrt{\sum_{m}\left(J_{m n} \times w_{m}\right)^{2}}}{z}
$$

where

$$
\begin{aligned}
& S_{n} \quad \text { is the composite sensitivity of the } n^{\text {th }} \\
& \text { parameter, } \\
& J_{m n} \quad \text { is the change in the simulated value for the } \\
& m^{\text {th }} \text { observation or prior information with } \\
& \text { respect to a change in the } n^{\text {th }} \text { parameter } \\
& \text { value (this } m \text {-by- } n \text { matrix is known as the } \\
& \text { Jacobian matrix), } \\
& W_{m} \quad \text { is the weight of the } m^{\text {th }} \text { observation, and } \\
& Z \quad \text { is the normalization factor (the number of } \\
& \text { observations). }
\end{aligned}
$$

The relative composite sensitivity (Watermark Numerical Computing, 2005) is the composite sensitivity multiplied by the parameter value, which allows for better comparison of the composite sensitivities of parameters of different magnitudes. However, care should be taken to limit comparisons of relative composite sensitivity to parameters of the same type, for example, hydraulic conductivities with other hydraulic conductivities.

Figure 25 shows the relative composite sensitivity of the 17 parameters estimated by using PEST. Kc, the coarsegrained end-member hydraulic conductivity, was the most sensitive of the K-related parameters and was the dominant parameter controlling lateral groundwater flow. About half as sensitive was $\mathrm{Kf}$, the fine-grained end-member hydraulic conductivity, which along with the vertical hydraulic conductivity of the Corcoran Clay (kvcc_lay8) were the dominant parameters controlling vertical groundwater flow. The vertical hydraulic conductivity of the Corcoran Clay was about half as sensitive as Kf. The streambed hydraulic conductivity for the lower reaches of the tributaries (sfr_k_lwr) was the fourth most sensitive value of hydraulic conductivity and was about twice as sensitive as that for the upper reaches (sfr_k_upp). A factor for adjusting $\mathrm{Kc}$ for the QPC deposits (kc_qpc_fac) was about twice as sensitive as the equivalent parameter for adjusting $\mathrm{Kf}$ for the QPC deposits (kf_qpc_fac). A factor for adjusting the horizontal hydraulic conductivity of the Corcoran Clay (fackhcorc) was insensitive. 
Several of the storage-related parameters were roughly equally sensitive, including the specific storages for below the Corcoran Clay (ss_bc), for the Corcoran Clay (ss_corc), and for the deep (below layer 8) part of the QPC deposits (ss_bcq), and the specific yields for the shallow (above layer 9) QPC deposits (sy_acq) and for the remaining alluvial deposits above and east of the Corcoran Clay (sy_ac). The least sensitive storage parameters were the specific storages for the non-QPC alluvial deposits above and east of the Corcoran Clay (ss_ac) and the shallow QPC deposits (ss_acq).

\section{Confidence Limits}

Another measure of parameter robustness is the 95-percent confidence limit for the estimated value of each parameter. The covariance between all parameter pairs is calculated in PEST as follows:

$$
\boldsymbol{C}=\frac{\Phi}{m-n} \times\left(\boldsymbol{J}^{t} \times \boldsymbol{Q} \times \boldsymbol{J}\right)^{-1}
$$

where

$C \quad$ is the covariance matrix for each parameter ( $n$-by- $n$ Matrix),

$\Phi$ is the objective function,

$m$ is the total number of observations,

$n$ is the total number of parameters,

$J \quad$ is the Jacobian matrix ( $m$-by- $n$ matrix of the change in the simulated value for the $m^{\text {th }}$ observation or prior information with respect to a change in the $n^{\text {th }}$ parameter value), and

$Q \quad$ is the $m$-by- $m$ diagonal matrix whose diagonal elements are $w_{\mathrm{m}}$ (weight of the $m^{\text {th }}$ observation).

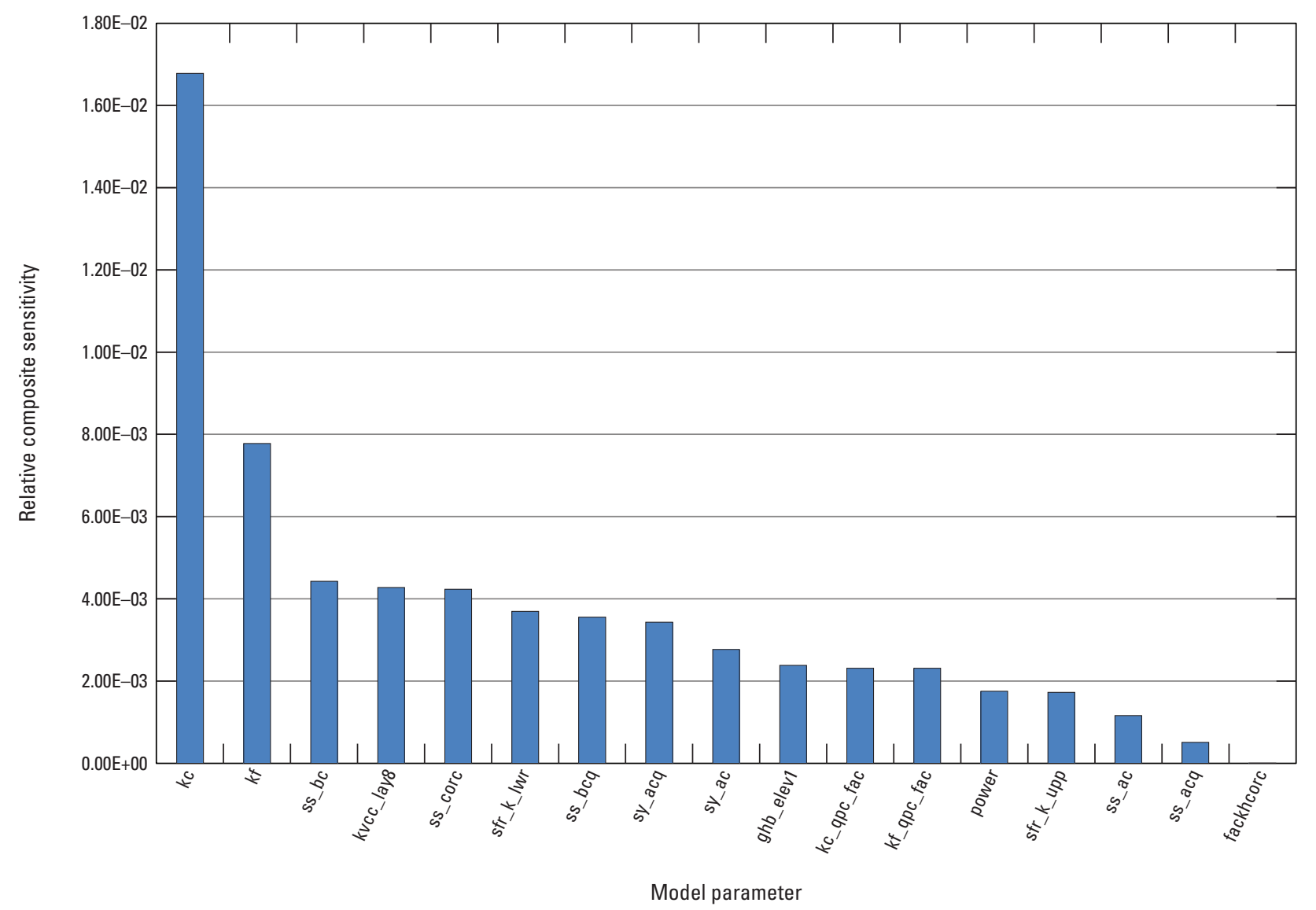

Figure 25. Relative composite sensitivities for model parameters estimated for the MERSTAN model, Modesto region, California. Model parameters are defined in table 5. 
The variance of each parameter value is the diagonal element of the covariance matrix for that parameter. The standard error of each parameter is the square root of the variance. Assuming a normal distribution, the 95-percent confidence interval in each direction around the estimated parameter value is 1.96 times the standard error.

Whereas the traditionally used composite sensitivity method provides only a relative indicator of sensitivity, confidence limits provide a range of sensitivity in units of actual parameter values. Confidence limits also take into account the correlation between parameters, which can be important in cases of highly correlated parameters. In these cases, the simulation results are insensitive to both parameters if they varied together. The values of these parameters can be more uncertain than is indicated by their individual sensitivities.

The 95-percent-confidence limits for the 17 estimated parameters in the MERSTAN model are shown in table 5. The confidence limits, in this case, agreed well with the relative composite sensitivities (fig. 25); those parameters with higher sensitivities had a narrower range in confidence limits than those with lower sensitivities.

\section{Model Results}

\section{Simulated Hydrologic Budgets}

Simulated hydrologic budgets for the MERSTAN model discussed in this section include the groundwater budget, the farm budget, and the streamflow budget.

\section{Groundwater Budget}

The average annual simulated groundwater budget for 1960-2004 is shown in table 6. About 62 percent of the average annual groundwater gain (water into the groundwater-flow system) was from deep percolation related to infiltration of precipitation and irrigation water (surface water and groundwater), as estimated by the Farm Process. The rest came from water released from groundwater storage (25 percent), subsurface inflow through the lateral generalhead boundaries ( 7 percent), stream leakage (4 percent), and reservoir leakage (1 percent). Note that simulated reservoir leakage was about 25 percent of the estimated value because of numerical instability and model convergence issues experienced at higher rates of leakage. Although this component of recharge could be underestimated, it represents a small percentage of total recharge.

About 51 percent of the average annual simulated groundwater loss (water out of the groundwater flow system) was from private irrigation pumping, as estimated by the Farm Process (table 6). The remaining losses were to groundwater storage (21 percent); subsurface outflow exiting the model through lateral general-head boundaries (12 percent); urban, drainage, and district irrigation pumping (11 percent); stream leakage (4 percent); and groundwater uptake by plants (1 percent). There was a net loss in groundwater storage of about 91,000 acre-ft/yr, consistent with the development of a cone of depression in the vicinity of the Eastside Water District (fig. 6) during the simulation period. A portion of this loss in groundwater storage was associated with simulated head declines near the northeastern model boundary that were greater than those observed.

Table 6. Average annual simulated water budget, 1960-2004, for the MERSTAN model, Modesto region, California.

[Abbreviations: acre-ft, acre foot; —, not applicable]

\begin{tabular}{lcr}
\hline \multicolumn{1}{c}{ Groundwater flow system description } & $\begin{array}{c}\text { Average annual simulated value } \\
\text { (acre-ft) }\end{array}$ & $\begin{array}{c}\text { Average annual simulated value } \\
\text { (percent of total) }\end{array}$ \\
\hline & Into the groundwater flow system (gain) & 25.2 \\
\hline Decrease in groundwater storage & 533,000 & 7.4 \\
General head boundaries & 157,000 & 0.7 \\
Reservoir leakage & 15,000 & 4.1 \\
Stream leakage & 87,000 & 62.5 \\
Deep percolation of irrigation and precipitation & $1,320,000$ & - \\
Total & $2,112,000$ & 20.9 \\
& Out of the groundwater flow system (loss) & 10.6 \\
Increase in groundwater storage & 442,000 & 12.5 \\
Pumpage-urban, drainage, and district wells & 225,000 & 3.6 \\
General head boundaries & 265,000 & 51.1 \\
Stream leakage & 76,000 & 1.2 \\
Pumpage-private irrigation, farm process & $1,080,000$ & - \\
Groundwater uptake by plants & 25,000 & - \\
Total & $2,113,000$ & - \\
\hline
\end{tabular}


Key components of the simulated groundwater budget are shown in figure 26, which shows annual groundwater gains and losses from 1960 to 2004. Annual variability was largely driven by climatic variability; large groundwater net gains were during wetter years, such as 1983 and 1998, and the large net losses were associated with drought periods, such as 1976-77 and 1987-92 (fig. 12).

\section{Farm Budget}

The water budget for the Farm Process represented the entire land area in the MERSTAN model, but did not include the streams or reservoirs. Natural vegetation and non-irrigated agriculture were included. Groundwater extraction for urban or domestic supply was not included. Specified components of the farm water budget included precipitation and irrigation deliveries, which are two of the four supply components, or the input side of the water budget. Private groundwater irrigation and uptake of shallow groundwater by plants were supply components simulated by the Farm Process. These four supply components are shown on the upper (positive) half of figure 27. On the lower half of the figure are crop consumptive use, runoff to streams, and deep percolation; these were simulated values and represented the output side of the water budget.

As a whole, the farm water budget was almost balanced and showed some annual variability, but no distinct trend. The variability was climatically driven and was essentially a damped version of the precipitation curve. The simulated groundwater uptake was a relatively small component of the farm water budget that was fairly steady over time, although, logically, it increased during wetter periods and decreased during drier conditions. Specified irrigation deliveries showed a slight decrease over time, and simulated private groundwater irrigation a slight increase. Simulated crop consumptive use was nearly constant and was the dominant component of the farm budget. Deep percolation varied climatically, but showed no long-term trend.

The simulated annual farm-well (private agricultural) pumpage from 1960 to 2004 and the monthly average during this period are shown in figure $28 \mathrm{~A}$ and $28 B$, respectively. Annual simulated farm-well pumpage ranged from about 780,000 acre-ft in 1982-83, a very wet period, to about $1,380,000$ acre-ft in 1977, 1988, and 1992, which were all drought years (fig. 28A); the average from 1960 to 2004 was about 1,000,000 acre-ft/yr. Monthly average farm-well pumpage was small during November-February and peaked

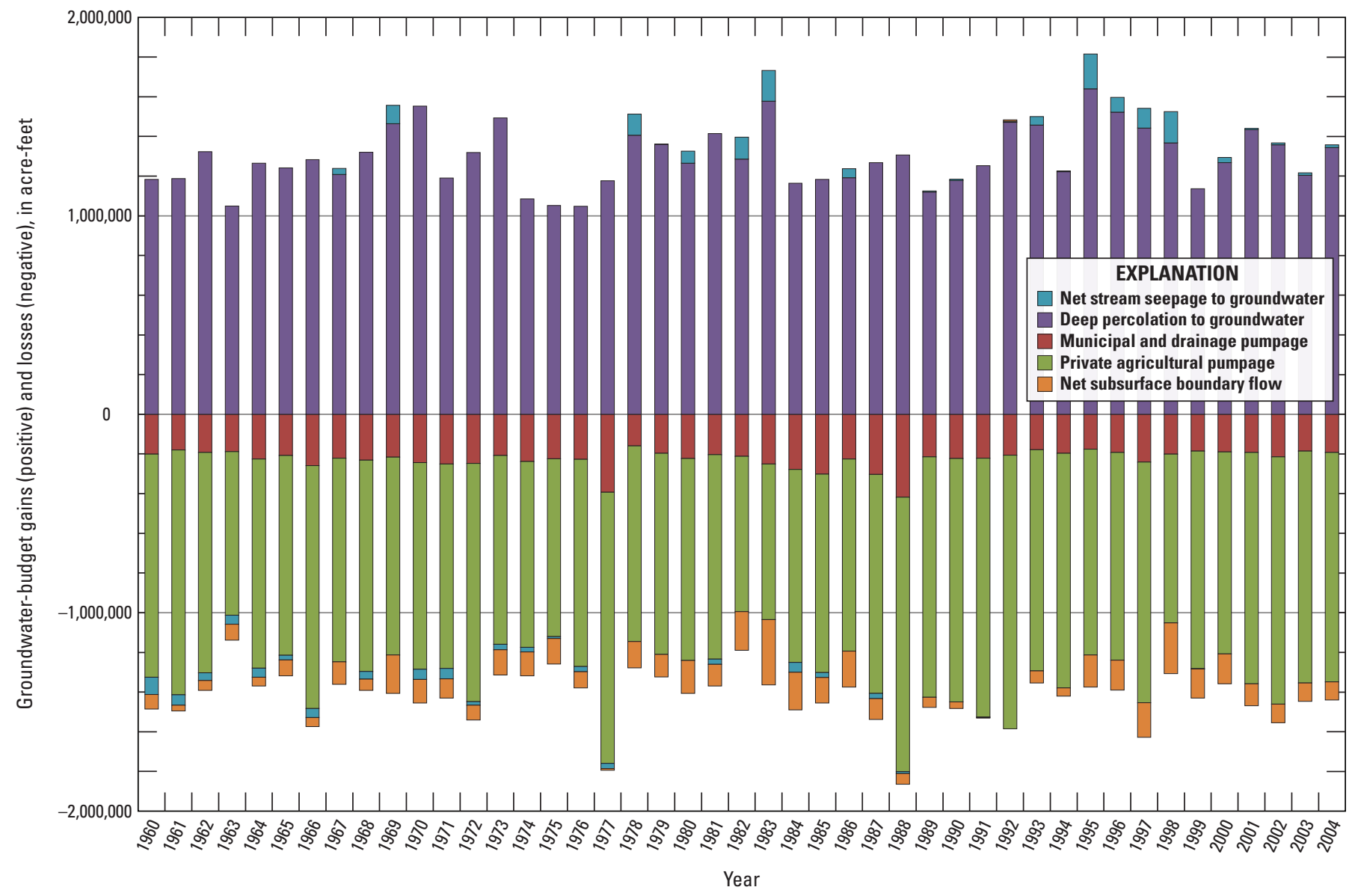

Figure 26. Key components of the simulated groundwater budget, 1960-2004, for the MERSTAN model, Modesto region, California. 
in June-July (fig. 28B). The spatial distribution of farm-well pumpage varied greatly, because some areas have substantial surface-water resources and some have none. The average linear rates (volume divided by area per unit time) ranged from less than $1 \mathrm{ft} / \mathrm{yr}$ to about $4 \mathrm{ft} / \mathrm{yr}$ (fig. 29).

The simulated annual deep percolation from 1960 to 2004 and the average monthly values over the same period are shown in figure $30 \mathrm{~A}$ and $30 \mathrm{~B}$, respectively. The annual deep percolation averaged about 1,360,000 acre-ft/yr. Annual variation from the average deep percolation was substantial and climate driven, ranging from a low of about $1,100,000$ acre-ft in 1976, a drought year, to a high of almost $1,700,000$ acre-ft in 1883 and 1995 , relatively wet years (fig. 30A). The simulated average monthly deep percolation varied greatly from a low in November of about 53,000 acre- $\mathrm{ft}$ to a high of 225,000 acre-ft in July, the peak of the irrigation season (fig. 30B). Between these extremes was a low peak in January associated with precipitation during the winter storm season. The irrigation season, and associated deep percolation, ramped up in March-April and ramped down in SeptemberOctober (fig. 30B).

Simulated deep percolation varied spatially, as shown in figure 31, ranging from less than $1 \mathrm{ft} / \mathrm{yr}$ in urban and some natural vegetation areas to a maximum of about $3.5 \mathrm{ft} / \mathrm{yr}$ in some agricultural areas.

Figures 32 and 33 show the spatial distribution of the sources and primary fates of water, respectively, as simulated by the Farm Process for the year 2004. The primary sources of water varied greatly, from about 60 percent irrigation deliveries (primarily surface water), where available, to 75 percent groundwater. Groundwater was taken up by crop roots primarily in the areas next to the San Joaquin River, where the water table was shallow (fig. 32). Not represented in figure 32 is irrigation water pumped from shallow wells in and next to the rivers in riparian areas, which is some combination of groundwater and induced seepage of surface water. The water needed to meet residual demand in the riparian areas, which averaged 137,000 acre-ft/yr, is provided by the Farm Process as an internal delivery and was not physically represented as groundwater pumpage or surfacewater diversions.

Evapotranspiration is the primary fate of water from sources depicted in figure 32; the vast majority of the remaining water became deep percolation (fig. 33). The proportion of water that became evapotranspiration varied primarily by irrigation efficiency, which is largely driven by the relative availability of surface water.

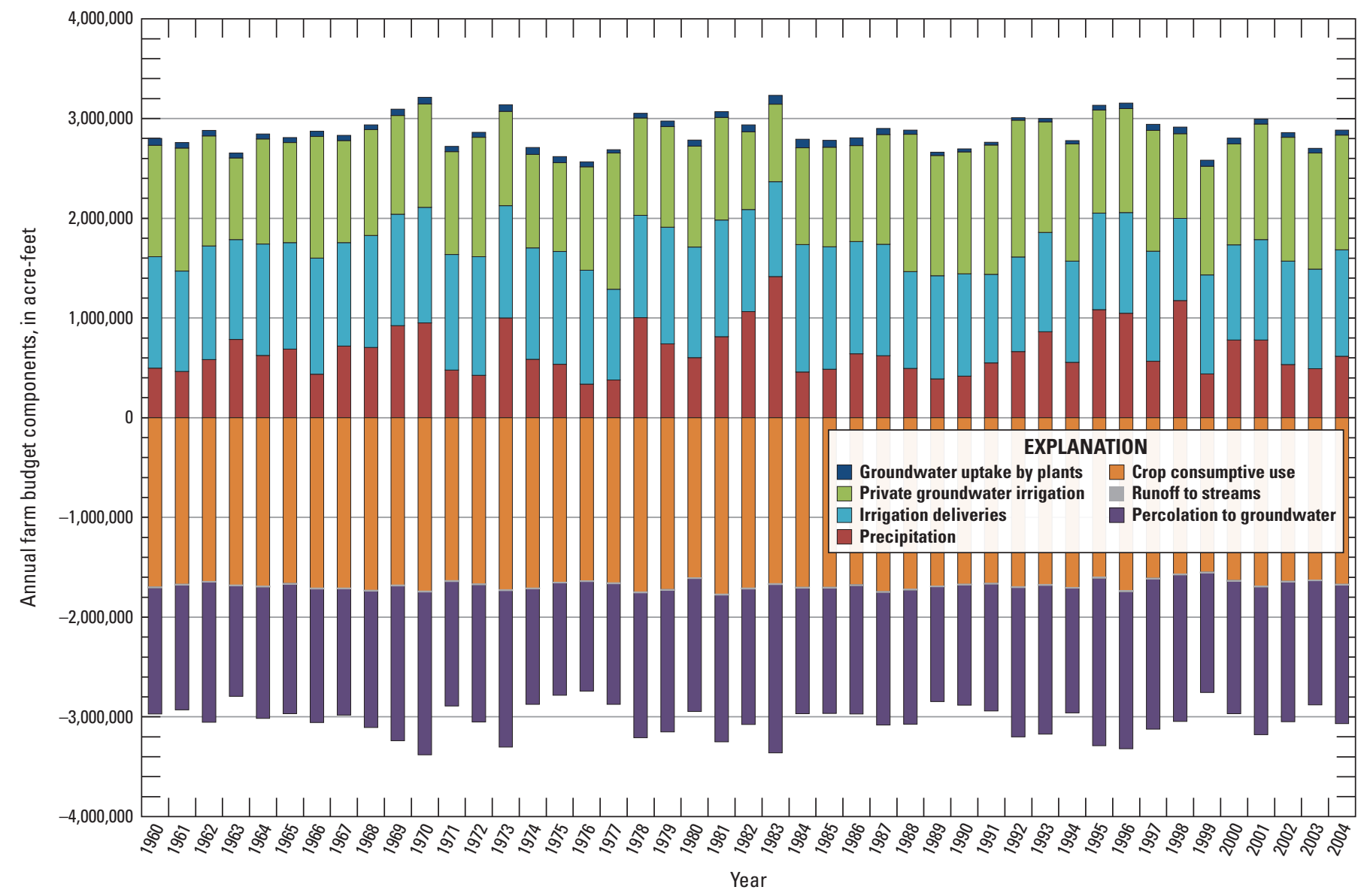

Figure 27. Simulated farm-budget results, 1960-2004, for the MERSTAN model, Modesto region, California. 

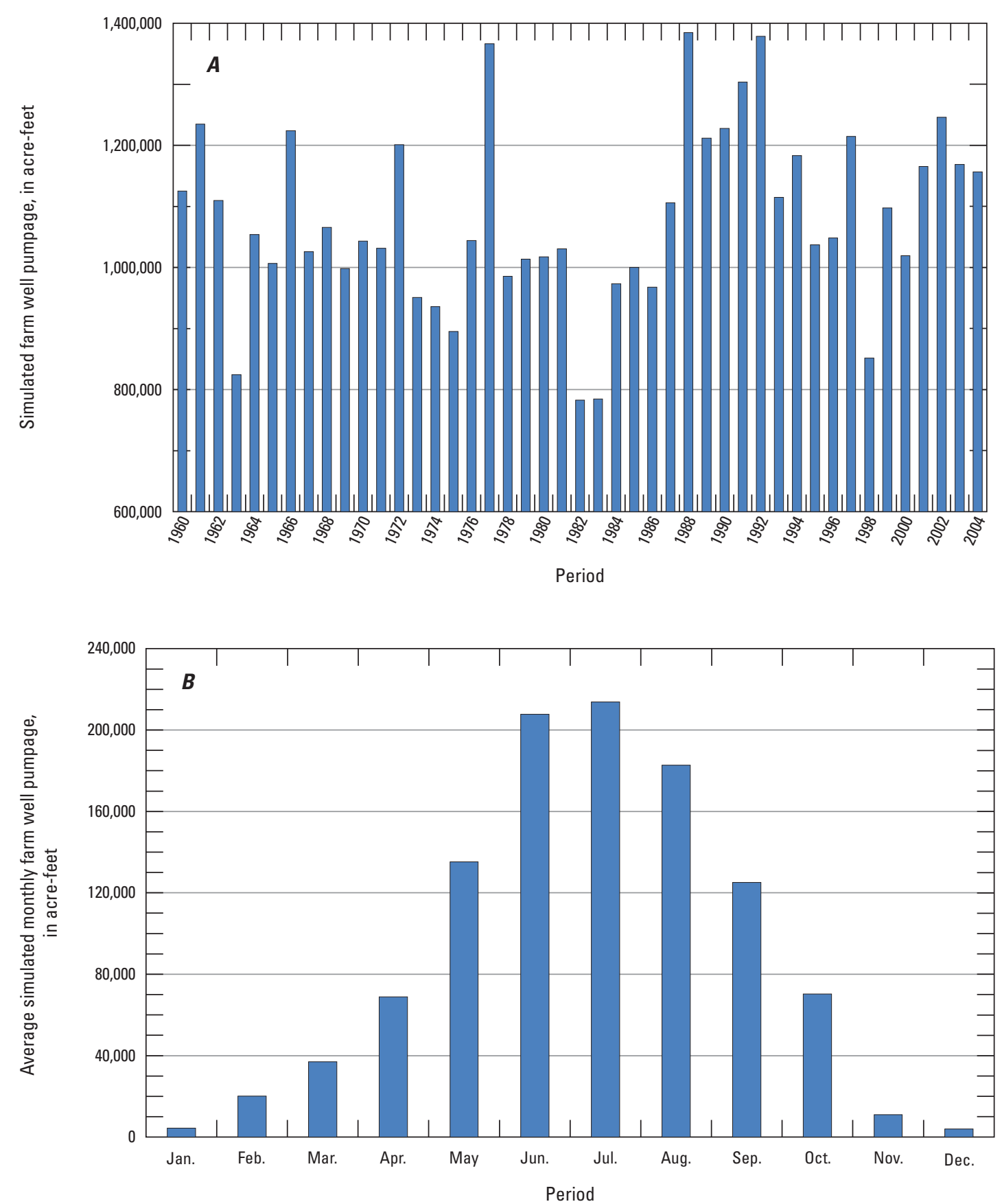

Figure 28. Farm-well (private agricultural) pumpage, 1960-2004, for the MERSTAN model, Modesto region, California: $A$, simulated annual and $B$, average monthly. 


\section{Model Results}

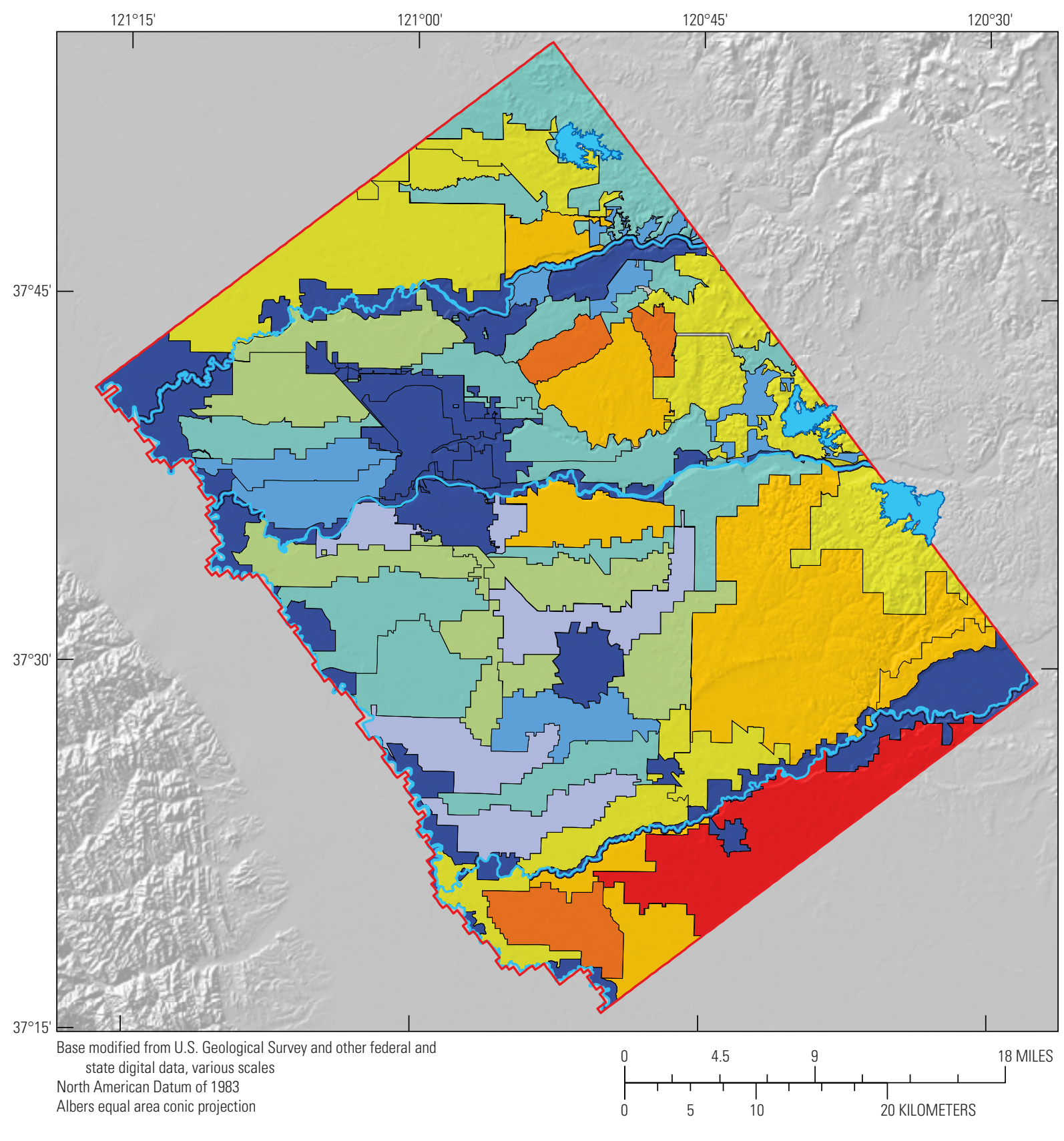

EXPLANATION

Simulated private agricultural pumpage, in feet per year

\begin{tabular}{|c|c|c|}
\hline $3.51-4.00$ & $1.01-1.50$ & Reservoirs \\
\hline $3.01-3.50$ & $0.51-1.00$ & Active model area \\
\hline $2.51-3.00$ & $0.01-0.50$ & River \\
\hline $2.01-2.50$ & 0.00 & \\
\hline $1.51-2.00$ & & \\
\hline
\end{tabular}

Figure 29. Average simulated rates of private agricultural pumpage for water-balance subregions of the MERSTAN model, 1960-2004, Modesto region, California. 

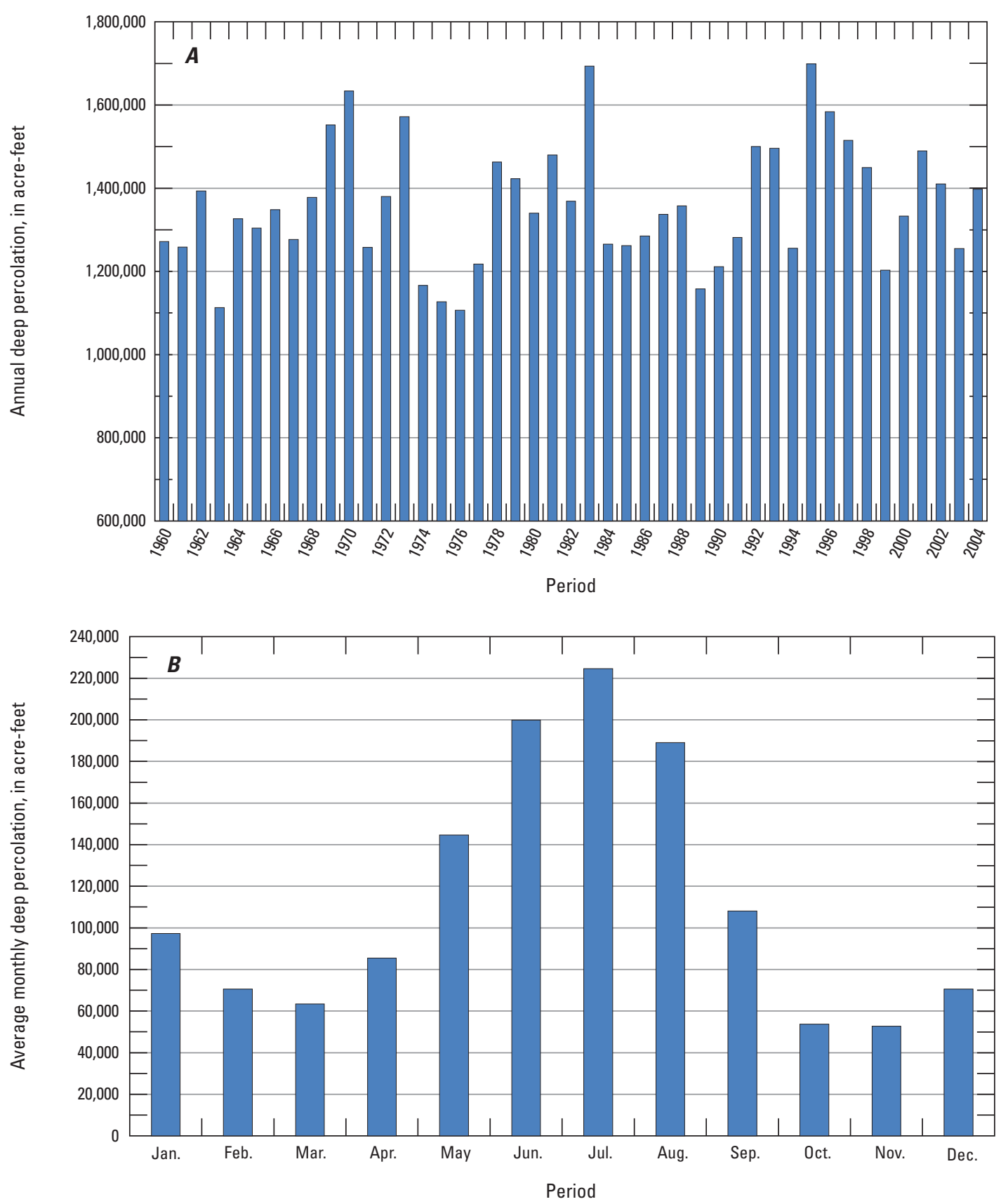

Figure 30. Simulated deep percolation for the MERSTAN model, 1960-2004, Modesto region, California: $A$, annual and $B$, average monthly. 


\section{Model Results}

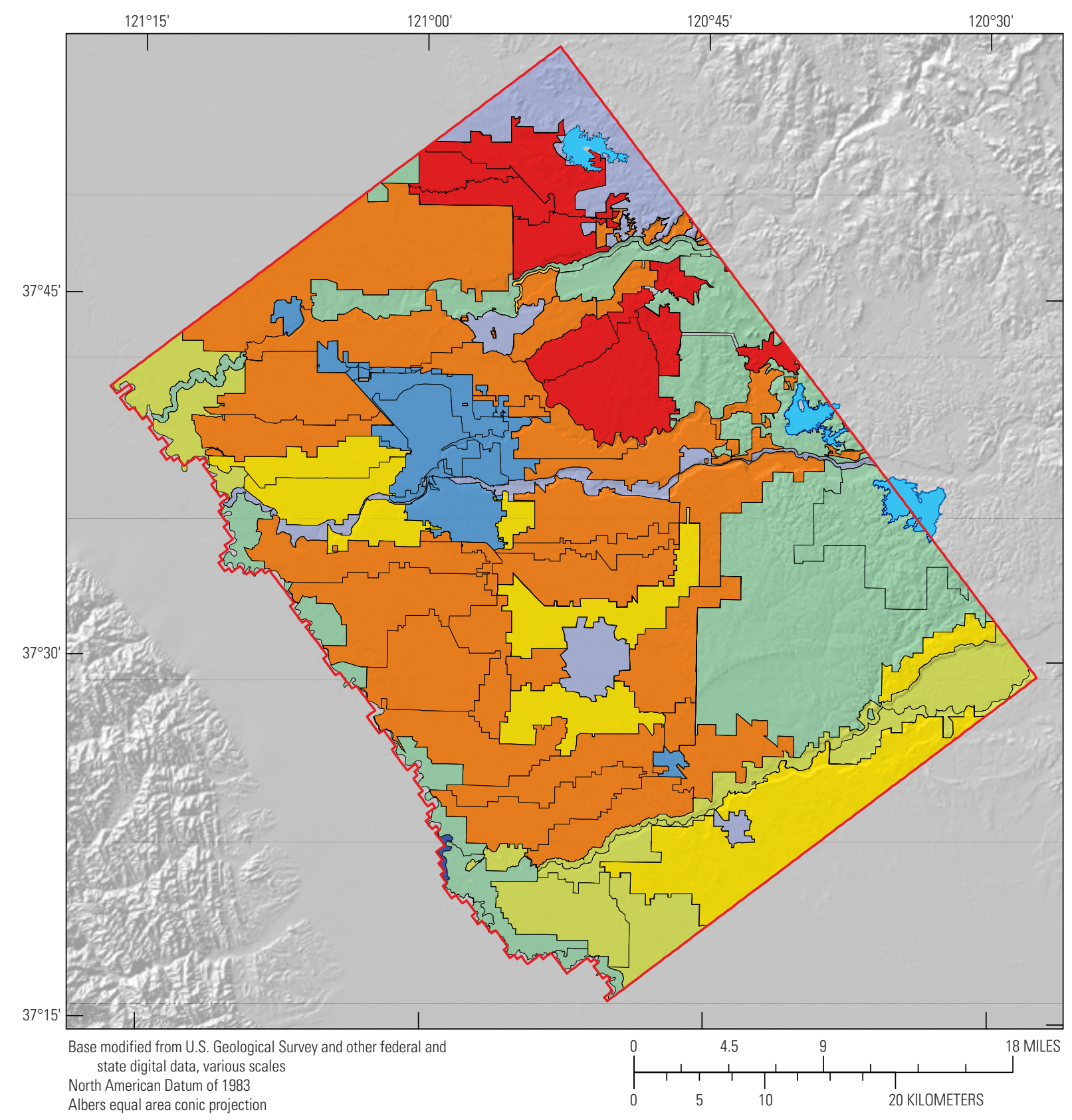

\section{EXPLANATION}

Average simulated deep percolation, in feet per year

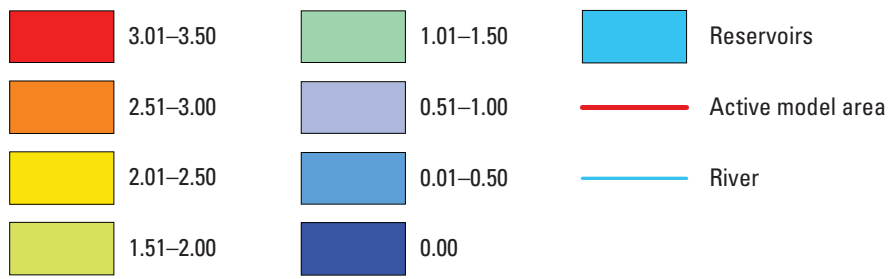

Figure 31. Simulated deep percolation for the MERSTAN model, 1960-2004, Modesto region, California: $A$, annual and $B$, average monthly. 


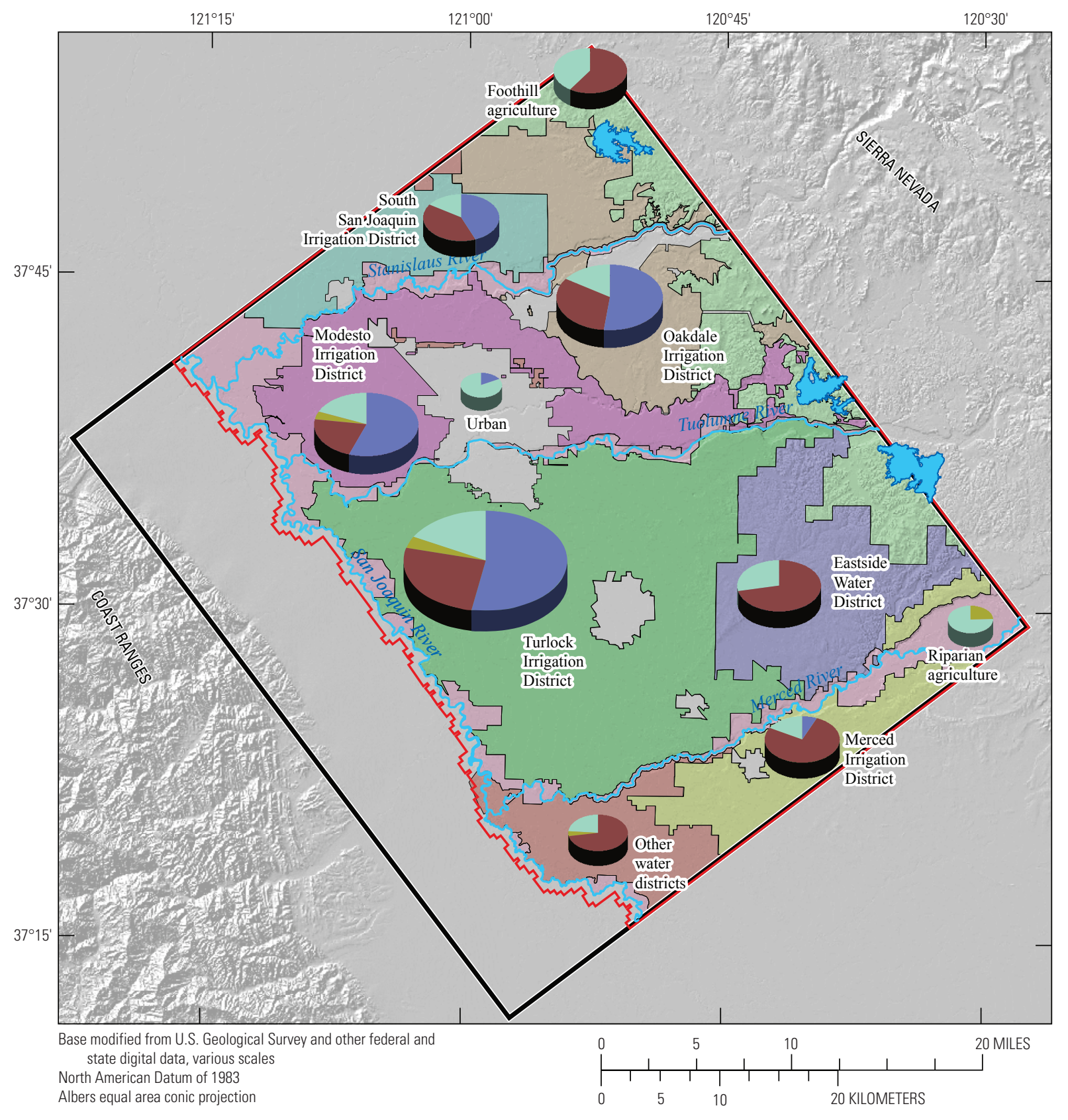

EXPLANATION

\begin{tabular}{|c|c|}
\hline \multicolumn{2}{|c|}{ Agriculatural or urban area represented by one or more water-balance subregions } \\
\hline Eastside Water District & Turlock Irrigation District \\
\hline Merced Irrigation District & Foothills \\
\hline Other water districts & Urban areas \\
\hline Modesto Irrigation District & Reservoirs \\
\hline Oakdale Irrigation District & Riparian and miscellaneous \\
\hline South San Joaquin Irrigation District & agricultur \\
\hline
\end{tabular}

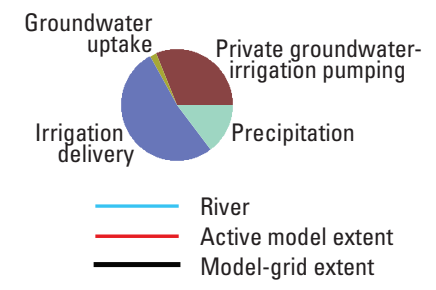

Figure 32. Simulated percentage of precipitation, groundwater uptake, irrigation delivery, and groundwater pumpage for irrigation, in 2004, for water-balance subregions of the MERSTAN model, Modesto region, California. 


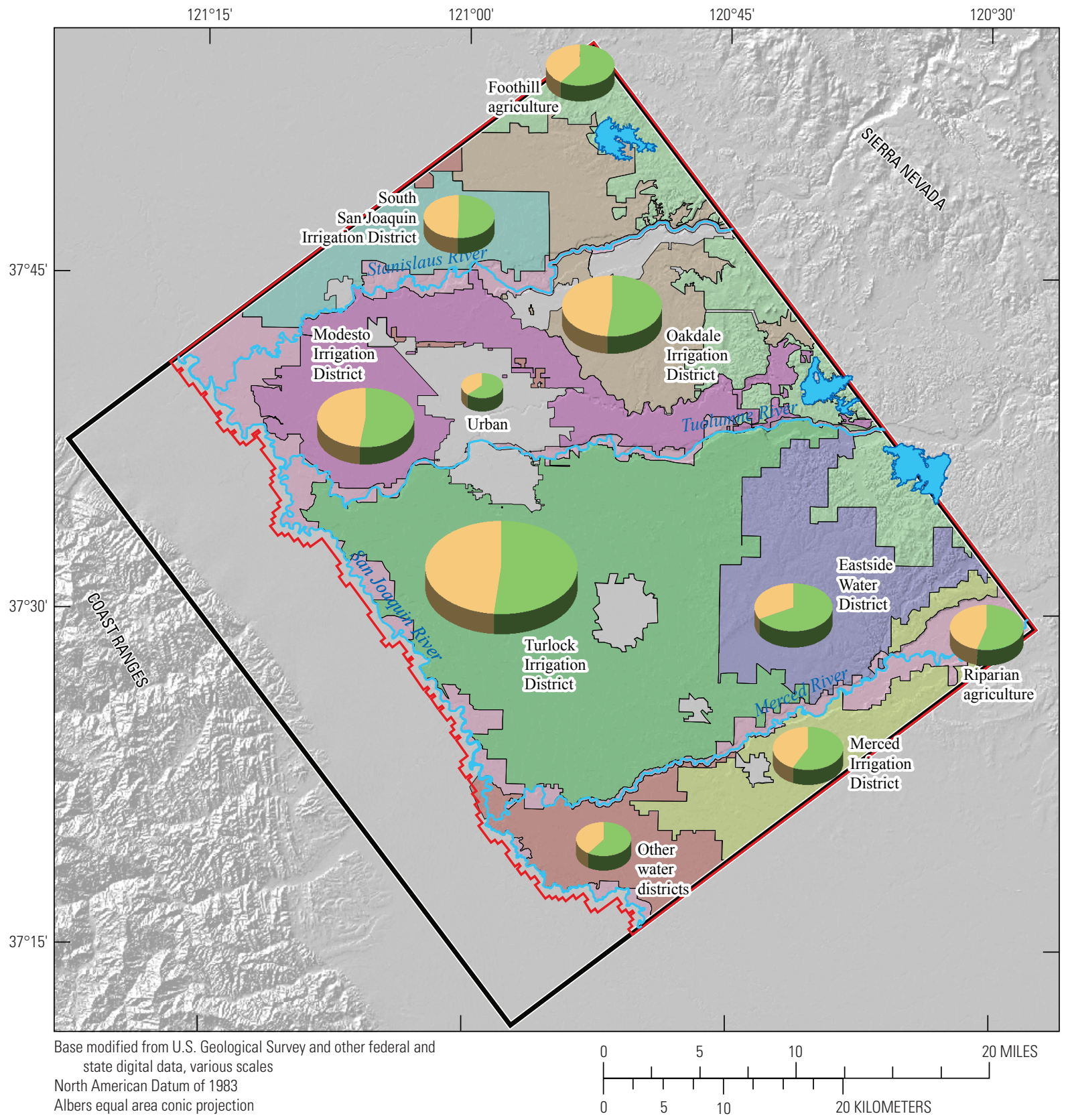

EXPLANATION

Agriculatural or urban area represented by one or more water-balance subregions
\begin{tabular}{|l|l|l|l}
\hline & Turlock Irrigation District & Evapotranspiration \\
\hline$\square$ & Eastside Water District & Foothills & Deep percolation \\
\hline & Merced Irrigation District & Urban areas & (groundwater recharge) \\
\hline & Other water districts & Reservoirs & River \\
\hline$\square$ & Modesto Irrigation District & Riparian and miscellaneous & - Active model extent \\
\hline & Oakdale Irrigation District & agricultural areas & - Model-grid extent
\end{tabular}

Figure 33. Simulated percentage of evapotranspiration and deep percolation (groundwater recharge), in 2004, for water-balance subregions of the MERSTAN model, Modesto region, California. The size of each pie chart is proportional to the total volume. 


\section{Streamflow Budget}

Average monthly specified streamflow to the MERSTAN model from 1960 to 2004 at the upstream ends of the San Joaquin River and the three major tributaries, and average monthly simulated streamflow on the San Joaquin River where it exits the model, near the Vernalis streamgage (fig. 1), is shown on figure 34. Also shown is the difference between total inflow and outflow, which represents the average net simulated monthly exchange between surface water and groundwater. For comparison to simulated outflow from the San Joaquin River, the monthly mean measured streamflow for the streamgage at Vernalis is shown for the same period.

Average monthly inflows and simulated outflows nearly mirrored one another, indicating a small degree of exchange between surface water and groundwater relative to total streamflow (fig. 34). Inflows and outflows were lowest in September, increased gradually through December and then more sharply to the peak in March, followed by a gradual decline to September. Most of the year-round inflows to the model were from the combined streamflow in the tributaries, although winter and spring inflows from the San Joaquin River represented about 40 percent of the total inflow during that period.

Average monthly simulated outflows from the San Joaquin River can be compared to the monthly mean measured streamflow at the nearby streamgage at Vernalis (fig. 34). Simulated outflows matched measured streamflow well during the summer months, but were consistently lower than the measured streamflow the remainder of the year. This indicated, on average, some combination of errors potentially associated with specified inflows, not accounting for discharge from delivery canals, underestimation of runoff within the model area, lower values of simulated groundwater discharge to streams compared to those observed, and higher values of simulated stream leakage to groundwater compared to those observed.

The average simulated stream gain or loss for each stream cell in the Stanislaus, Tuolumne, Merced, and San Joaquin Rivers from 1960 to 2004 is shown in figure 35. The Stanislaus River generally gained upstream (in the northeastern part of the study area) and switched between gaining and losing midstream and downstream. The Tuolumne River gained or had balanced gains and losses over most of its length. The Merced River showed greater variability; it was losing at relatively high rates upstream, switched between gaining and losing midstream, and had low variability and balanced gains and losses downstream. The San Joaquin River primarily gained at a moderate rate throughout its length in the study area.

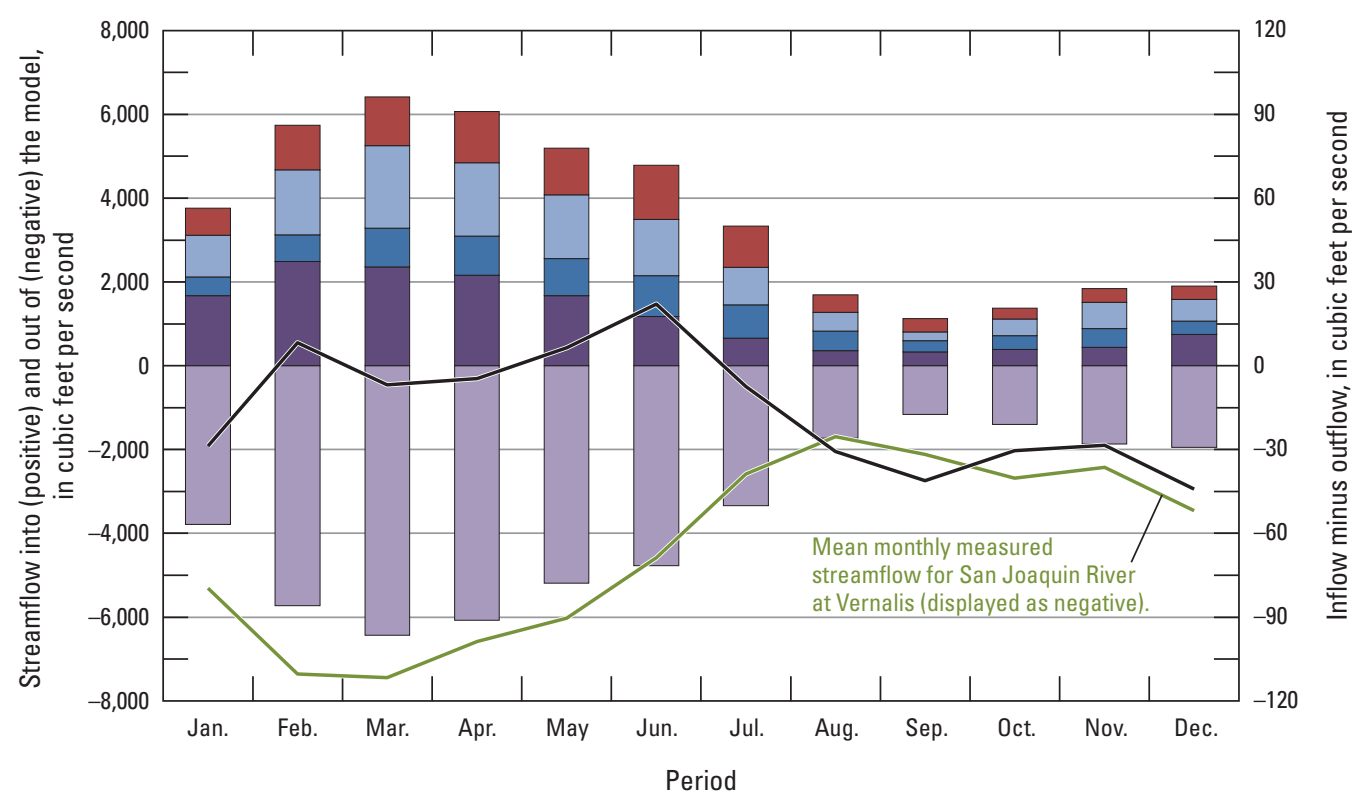

EXPLANATION

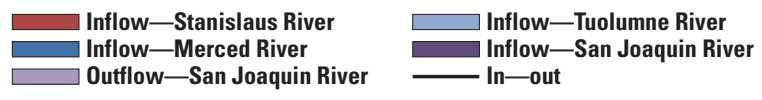

Figure 34. Monthly specified stream inflow for 1960-2004 at the MERSTAN model boundaries for the Stanislaus (SR), Tuolumne (TR), and Merced (MR) Rivers and at the upper end of the San Joaquin (SJR) River; the mean monthly simulated outflow from the model at the lower end of the San Joaquin River; and the difference between the total stream inflows and simulated outflow for the Modesto region, California. Also shown is the mean monthly measured streamflow for the San Joaquin River at Vernalis gaging station (11303400), which was near the simulated outflow. 

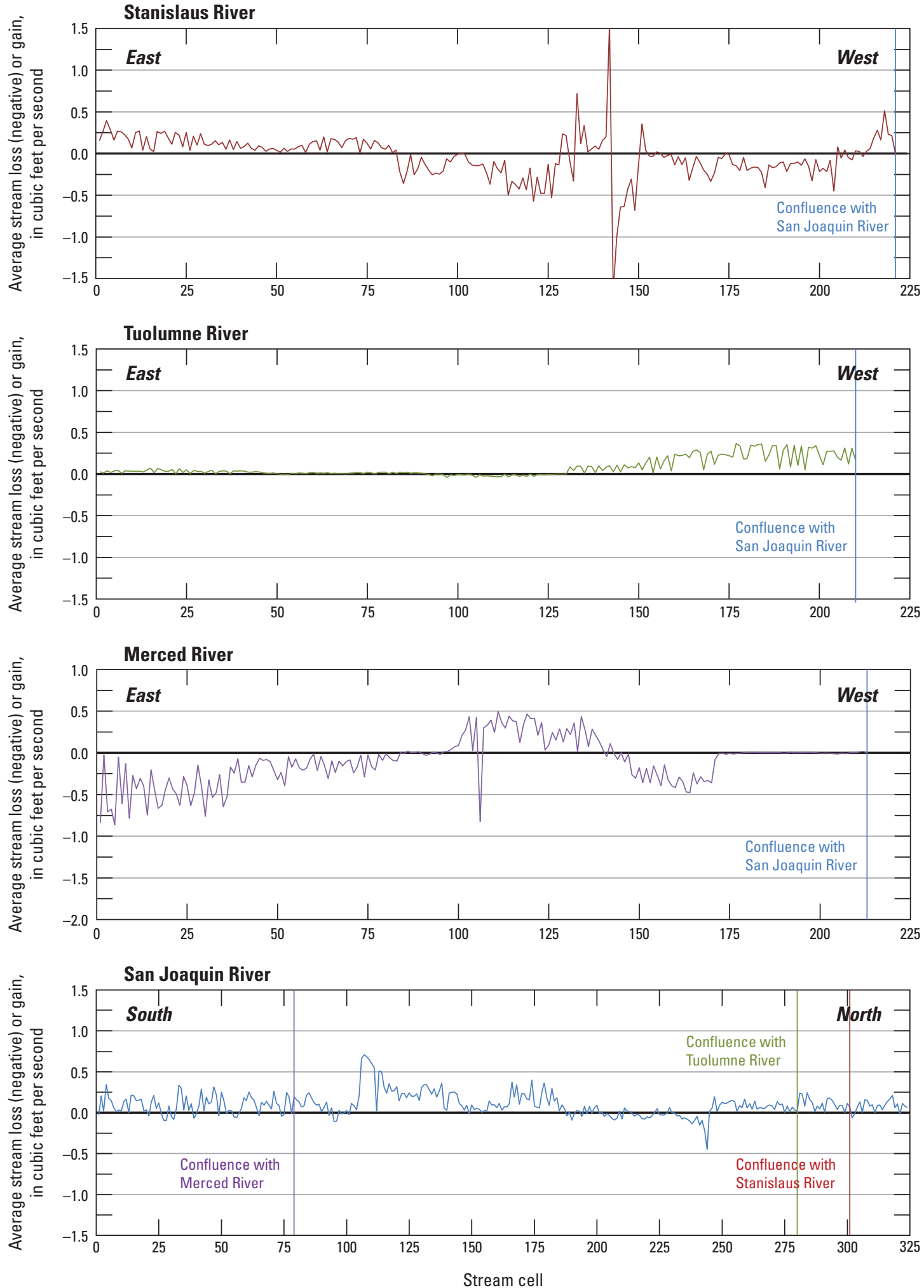

Figure 35. Average simulated stream-cell loss (negative) or gain, 1960-2004, for the Stanislaus, Tuolumne, Merced, and San Joaquin Rivers, MERSTAN model, Modesto region, California. 
Average annual simulated stream gain or loss for all stream cells in the upstream, midstream, and downstream reaches of the Stanislaus, Tuolumne, Merced, and San Joaquin Rivers from 1960 to 2004 is shown in figure 36. The general gaining or losing conditions by position along the rivers evident in figure 36 is the same as described previously and shown on figure 35; figure 36 shows annual variability in gaining and losing conditions. On the Stanislaus River, the simulated upstream reach always gained (on an annual basis); the midstream almost always lost; and the downstream generally lost, but occasionally gained during wetter years. The upstream and downstream reaches of the Tuolumne River always gained, and the midstream reach, which showed little exchange, generally gained with occasional losses. On the Merced River, the upstream and downstream reaches almost always lost; the midstream reach generally gained, but occasionally lost during wet years. The San Joaquin River, which is shown in figure 36 as five reaches, as broken primarily by the confluences with the tributaries, showed predominantly gaining conditions in all reaches, with occasional losses in reaches $1-4$.

Simulated gains (about $1.2 \mathrm{cfs} / \mathrm{mi}$, approximately four stream cells) on the Merced River at the location of the Zamora (2006) study, west of highway 99, were in agreement with those estimated by that study (about $1 \mathrm{cfs} / \mathrm{mi}$ ). The simulated average gain on the San Joaquin River was about $0.52 \mathrm{cfs} / \mathrm{mi}$ (approximately 4 stream cells), which was lower than, but in reasonable agreement with, the estimate of about $1 \mathrm{cfs} / \mathrm{mi}$ by Zamora and others (2013)

\section{Map of Simulated Water-Table Elevation}

A contour map of simulated heads representing the water table during March 2000 is shown in figure 37. The simulated contours compare well to those drawn on the basis of measured water levels during spring 2000 (fig. 6), with two notable differences. Simulated heads in the southeast corner of the model, near the Merced River, are higher than those based on measurements; however, measurements were not available in that area for constraining the contours or for calibrating the model. Given the simulated losses from the upper reaches of the Merced River, and the likelihood of losses occurring in that area, adjacent to the large cone of depression, the simulated heads are assumed to be reasonable.

The second notable feature that differed between the contours of simulated head and measured water levels was the position of the cone of depression in the southeastern part of the model area (figs. 6, 37), underlying the Eastside Water District. The center of the simulated cone of depression, which was of similar magnitude as the observed center, was northeast of the cone of depression drawn on the basis of measured data. This shift in location was potentially caused by several model-related factors, including possible perching of groundwater above the regional water table near and east of the city of Turlock, which was not simulated; the simulated distribution of pumpage, which was not well known; the specification of the northeastern no-flow boundary condition; and simulation of reduced reservoir leakage. Perching, which would cause a disconnect between shallow perched water and a deeper water table drawn down by local and Eastside Water District groundwater pumping, would decrease the gradient and quantity of northeastward flow toward the cone of depression and draw the cone southwestward. The distribution of pumpage was simulated evenly throughout Eastside Water District; if, in reality, pumping was concentrated in a smaller area, the cone of depression would be centered near that area. A third factor that could explain the offset between the measured and simulated cones of depression is the no-flow boundary condition specified along the northeastern model boundary. If significant flow were simulated through this boundary, this flow would enter the cone of depression from the east, causing it to move southwestward. Finally, if increased leakage from Turlock Lake and Modesto Reservoir were simulated, this flow would also cause the cone of depression to move southwestward.

Stream-aquifer interactions are also illustrated in the simulated (and observed) contour maps. Where the contours "V" in the upstream direction, the stream was gaining from groundwater inflow; the stream was losing where contours "V" in the downstream direction. 

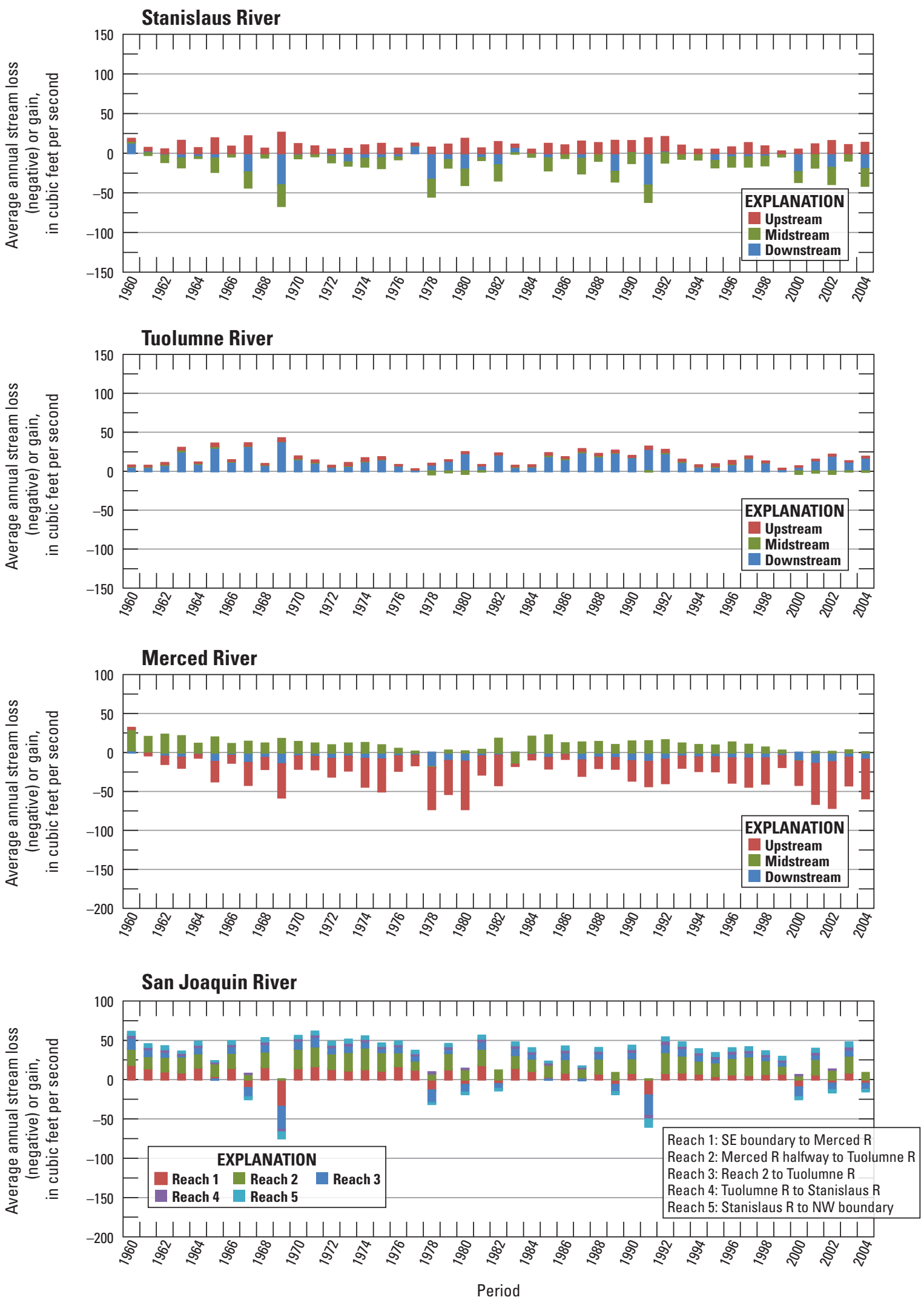

Figure 36. Annual simulated stream loss (negative) or gain for the Stanislaus, Tuolumne, Merced, and San Joaquin Rivers, MERSTAN model, Modesto region, California. Upstream, midstream and downstream reaches are roughly thirds of the river length. 


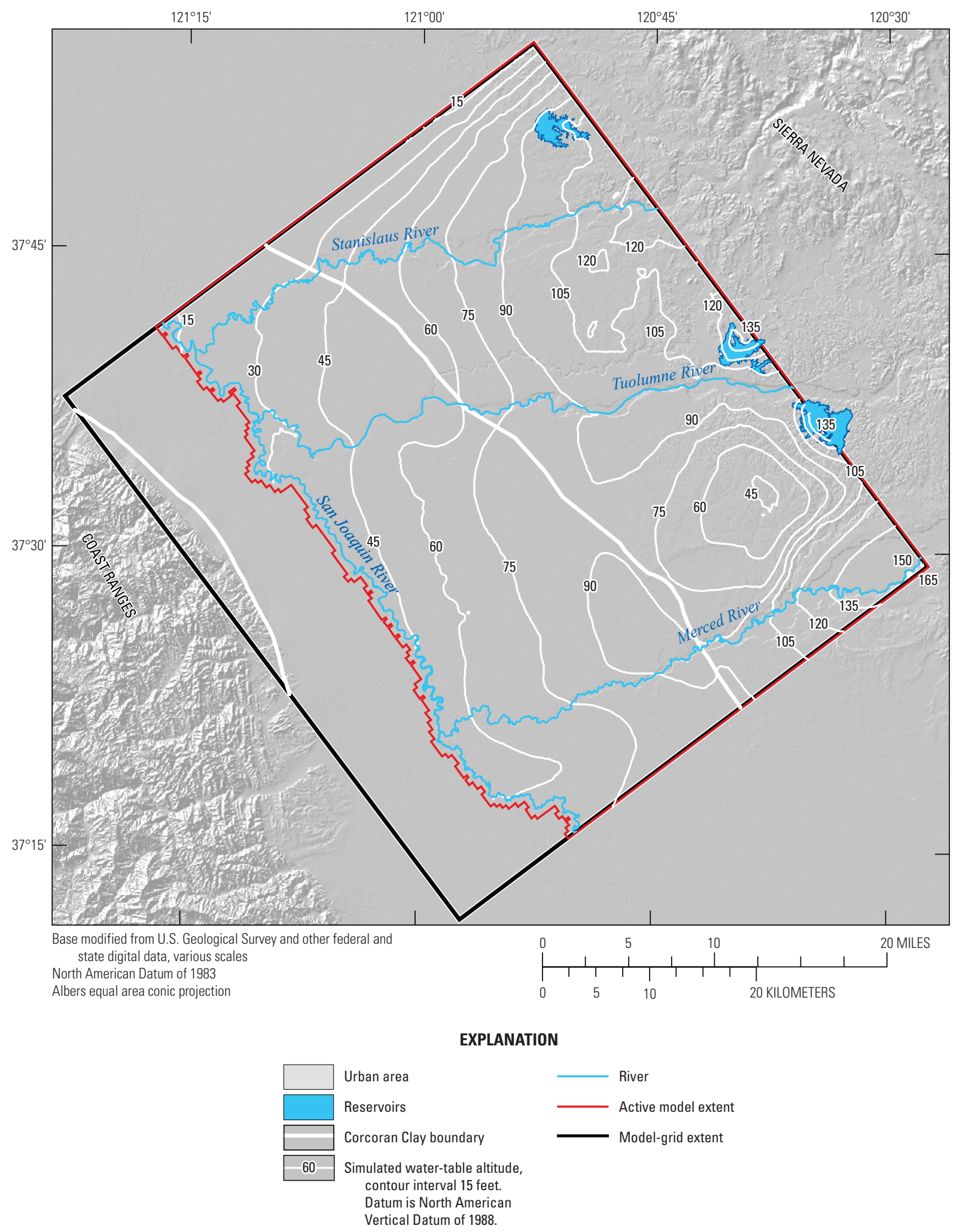

Figure 37. Contour of the simulated water table during March 2000, MERSTAN model, Modesto region, California. 


\section{Limitations and Appropriate use of the Model}

The MERSTAN model was developed for the purpose of evaluating the relative effects of potential water-management actions on a regional scale. Limitations of numerical models, assumptions made during model development, and results of model calibration and sensitivity analysis are factors that constrain the appropriate use of the model.

\section{Limitations}

Approximations in the MERSTAN model related to numerical convergence issues included the simulation of all layers as confined and a 75-percent reduction in the total estimated leakage from the three reservoirs in the model area. Confined simulation of the layer containing the water table, which varied from layers 1 to 8 in the MERSTAN model, did not allow transmissivity, which governs lateral flow, to vary with changes in the position of the water table. Error associated with this approximation is greatest where the ratio of water-level change to specified aquifer thickness is greatest (Sheets and others, 2015), which was in the vicinity of the Eastside Water District (fig. 7). The initial estimate of reservoir leakage was reduced by 75 percent to improve numerical stability prior to the PEST calibration, which requires numerical convergence.

Although the finely-discretized MERSTAN grid and incorporation of aquifer-system heterogeneity made the simulation of some degree of local-scale management actions and associated hydrologic responses possible, it should be recognized that model accuracy associated with local-scale features, such as wells, is limited by the resolution of the model grid. Local model accuracy also can be affected by proximity to the lateral boundary conditions, which could not be set appropriately for the evaluation of a given management action that influences hydraulic head at the model boundary. For example, a scenario involving increased groundwater pumpage near a general-head boundary, for which heads are specified, would yield incorrect results if the pumping affected simulated heads next to the boundary condition.

The accuracy of model results in time and space is strongly related to the availability and accuracy of temporal and spatial input data and calibration criteria (groundwater levels and gaged streamflow) for comparison with simulation results during model calibration. Users of the MERSTAN model should review sections of this report that discuss these aspects.

There are unknowns associated with the lateral boundary conditions. The northeastern boundary was assumed to be no-flow, but flow through that boundary into the model area would improve model fit in the northeastern corner and near the cone of depression in the Eastside Water District. The eastern end of the northwestern boundary and the entire southwestern boundary are poorly constrained (water-level data were not available); the associated assumptions made could be incorrect.

Uncertainty associated with irrigation deliveries and efficiencies (Farm Process input), and closely associated private groundwater pumpage for irrigation (Farm Process output), was substantial for the MERSTAN model. Different assumptions made for these and other types of model input could result in different model output, particularly the estimate of private irrigation pumpage. Monthly crop coefficients, which were not varied annually, can often be offset relative to monthly specified irrigation deliveries because of climatic variability; this could be the primary cause of rejected deliveries. If so, the 10-percent increase in the crop coefficients applied to reduce rejected deliveries, which also caused an increase in groundwater pumpage, would not have been appropriate.

The calibration results showed that streamflow simulated by the MERSTAN model was low compared with observed streamflow. Future inclusion of canal discharge to streams could improve this. The simulated interaction between groundwater and surface water represented a small percentage of streamflow, and limited measurements or estimates of this exchange were available for calibration or comparison. Appropriate caution should be taken by the MERSTAN model user in interpreting results related to streamflow and, particularly, to the interaction of groundwater and surface water.

Note that although land subsidence has not historically been a substantial issue in the study area, recent work showed minor subsidence in a narrow north-south band south of the city of Turlock during 2008-10 (Sneed and others, 2013). As of the writing of this report, the MERSTAN model does not simulate aquifer-system compaction from fluid withdrawal, the process that caused the land subsidence in this region. This capability exists in MODFLOW-OWHM, and simulation of aquifer-system compaction could be a consideration for evaluation of future scenarios that involve head declines below historic low levels.

\section{Appropriate use of the MERSTAN model}

Results from the MERSTAN model should be interpreted generally in time and space, and are more suited for comparative analysis rather than for prediction of absolute changes. A numerical hydrologic model is a means of portraying conceptual views of a hydrologic system. Because these systems are inherently complex, simplifying assumptions are made during the development and application of such model codes (Anderson and Woessner, 1992). Models solve for average conditions in each model cell for which the parameters are interpolated or extrapolated from measured values or values estimated during calibration. As such, ideally, the model represents the general characteristics of the hydrologic system so that the model can be used to simulate potential, realistic hydrologic responses to various proposed management actions. 


\section{Summary}

Strategies for managing water supplies and groundwater quality in the Modesto region of the eastern San Joaquin Valley, California, are being formulated and evaluated by the Stanislaus and Tuolumne Rivers Groundwater Basin Association (STRGBA). Management issues and goals in the basin include: an area in the southwestern part of the basin that requires drainage to sustain agriculture; intra- and interbasin migration of poor-quality groundwater; and efficient management of surface-water and groundwater supplies. To aid in the evaluation of water-management strategies, the U.S. Geological Survey (USGS) and the STRGBA have developed a hydrologic model, MERSTAN, that simulates monthly groundwater and surface-water flow as influenced by aquifer-system properties, annual and seasonal variations in climate, surface-water flow and availability, water use, and land use.

The model area includes the San Joaquin River and three major tributaries, the Stanislaus, Tuolumne, and Merced Rivers. The largely agricultural area has a semi-arid climate and is underlain by a thick, alluvial aquifer system made up of gravel, sand, silt and clay that is partly confined by the regionally extensive Corcoran Clay, a lacustrine (lakebed) deposit. The aquifer system was represented in the model by using 16 wedge-shaped layers that thicken from the foothills of the Sierra Nevada to the San Joaquin River; laterally, the model-grid resolution was about 0.25 -mile square.

Available measurements of groundwater pumped for municipal, irrigation, and drainage purposes, and deliveries of surface water and groundwater, were specified in the model. Private irrigation pumpage values for agricultural use and recharge associated with agricultural and other land uses were estimated by using the Farm Process in MODFLOW-OWHM, which simulates landscape processes associated with irrigated agriculture and other land uses.

The distribution of hydraulic conductivity in the aquifer system was constrained by using data from more than 3,500 drillers' logs, which were the basis of a threedimensional model of sediment texture (Burow and others, 2004).

The model was calibrated to 4,061 measured groundwater levels in 109 wells and 2,739 mean monthly values of streamflow (derived from measurements at 6 streamgages) during 1960-2004 by using a semi-automated method of parameter estimation. The model fit to water levels was good, having an absolute mean residual of 0.8 feet (ft); 74 percent of simulated heads were within $10 \mathrm{ft}$ of measured, and 89 percent were within $20 \mathrm{ft}$. The MERSTAN model underestimated measured streamflow, but the model fit was reasonable overall. The absolute mean residual of streamflow was 780 cubic feet per second (cfs); 68 percent of simulated streamflows were within $500 \mathrm{cfs}$ of observed, and 82 percent were within $1,000 \mathrm{cfs}$. Hydrographs both of groundwater levels and streamflow indicated overall an acceptable fit to observed trends.

The model results showed private agricultural pumpage ranged from about 780,000 to 1,380,000 acre-feet per year (acre-ft/yr) and averaged about 1,000,000 acre-ft/yr from 1960 to 2004; for comparison, the average irrigation deliveries were 1,100,000 acre-ft/yr. Simulated private agricultural pumpage varied spatially, largely with the availability of surface water, and ranged from a linear rate of less than 1 to about 4 feet per year (ft/yr). Simulated deep percolation of irrigation and precipitation, or groundwater recharge, varied with climate and land use from about $1,100,000$ to 1,700,000 acre-ft/yr, averaging 1,360,000 acre-ft/yr. Deep percolation varied spatially from a linear rate of less than 1 to about $3.5 \mathrm{ft} / \mathrm{yr}$. A key limitation of the model with respect to estimating these large components of the water budget was the uncertainty associated with actual deliveries and irrigation efficiencies and the lack of metered data for private agricultural groundwater pumpage. Different assumptions with respect to irrigation deliveries and efficiencies, and other model input, would result in different estimates of private agricultural groundwater use.

The simulated exchange between groundwater and surface water was a small percentage of streamflow, ranging from a loss of about $1.5 \mathrm{cfs}$ per stream cell (approximately four cells per mile) to a gain of about the same, but more typically was within the range of plus or minus $0.5 \mathrm{cfs}$ per stream cell, or about $2 \mathrm{cfs}$ per mile. The simulated exchange compared reasonably with the limited available independent estimates; however, substantial uncertainty is associated with these estimates. 


\section{References Cited}

Anderson, M.P. and Woessner, W.W., 1992, Applied groundwater modeling - Simulation of flow and advective transport: San Diego, Calif., Academic Press, 381 p.

Allen, R.G., Pereira, L.S., Raes, Dirk, and Smith, Martin, 1998, Crop evapotranspiration - Guidelines for computing crop water requirements: Food and Agriculture Organization of the United Nations, Rome, Italy, FAO Irrigation and Drainage Paper 56, http://www.fao.org/docrep/x0490e/x0490e00.htm.

Arkley, R.J., 1962, Soil survey of Merced area, California: U.S. Department of Agriculture, Soil Conservation Service, Soil Survey series 1950, no. 7, 131 p., 101 pls., http://www.nrcs.usda.gov/Internet/FSE_MANUSCRIPTS/ california/mercedCA1962/mercedCA1962.pdf.

Bartow, J.A., 1991, The Cenozoic evolution of the San Joaquin Valley, California: U.S. Geological Survey Professional Paper 1501, 40 p., http://pubs.er.usgs.gov/publication/pp1501.

Belitz, Kenneth, and Phillips, S.P., 1995, Alternative to agricultural drains in California's San Joaquin ValleyResults of a regional-scale hydrogeologic approach: Water Resources Research, v. 31, no. 8, p. 1845-1862, http://dx.doi.org/10.1029/95WR01328.

Brush, C.F., Belitz, Kenneth, and Phillips, S.P., 2004, Estimation of a water budget for 1972-2000 for the Grasslands area, central part of the western San Joaquin Valley, California: U.S. Geological Survey Scientific Investigations Report 2004-5180, 59 p., http://pubs.er.usgs.gov/publication/sir20045180.

Burow, K.R., Shelton, J.L., Hevesi, J.A., and Weissmann, G.S., 2004, Hydrogeologic characterization of the Modesto area, San Joaquin Valley California: U.S. Geological Scientific Investigations Report 2004-5232, 62 p., http://pubs.er.usgs.gov/publication/sir20045232.

Burow, K.R., Jurgens, B.C., Kauffman, L.J., Phillips, S.P., Dalgish, B.A., and Shelton, J.L., 2008, Simulations of ground-water flow and particle pathline analysis in the zone of contribution of a public-supply well in Modesto, eastern San Joaquin Valley, California: U.S. Geological Survey Scientific Investigations Report 2008-5035, 41 p., http://pubs.er.usgs.gov/publication/sir20085035.

California Department of Water Resources, 1968, Municipal and industrial water use: California Department of Water Resources Bulletin 166-1, http:/www.water.ca.gov/waterdatalibrary/docs/historic/ Bulletins/Bulletin_166/Bulletin_166-1_1968.pdf.
California Department of Water Resources, 1975, Urban water use in California: California Department of Water Resources Bulletin 166-2, http://www.water.ca.gov/waterdatalibrary/docs/historic/ Bulletins/Bulletin_166/Bulletin_166_1975.pdf.

California Department of Water Resources, 1983, Urban water use in California: California Department of Water Resources Bulletin 166-3, http://www.water.ca.gov/waterdatalibrary/docs/historic/ Bulletins/Bulletin_166/Bulletin_166_1983.pdf.

California Department of Water Resources, 1994, Urban water use in California: California Department of Water Resources Bulletin 166-4, 48 p., http://www.water.ca.gov/ historicaldocs/irwm/b166-1994/uwundx.html.

California Department of Water Resources, 2001a, Land use for Merced County, California, for 1995 [digital data]: California Department of Water Resources, Division of Planning, Statewide Planning Branch, Land and Water Use, www.water.ca.gov/landwateruse/lusrvymain.cfm.

California Department of Water Resources, 2001b, Land use for San Joaquin and Stanislaus Counties, California, for 1996 [digital data]: California Department of Water Resources, Division of Planning, Statewide Planning Branch, Land and Water Use, www.water.ca.gov/landwateruse/lusrvymain.cfm.

California Division on Mines and Geology, 1966, Geologic map of California, San Jose sheet: California Department of Conservation, scale 1:250,000, 2 sheets, http://ngmdb.usgs.gov/Prodesc/proddesc_453.htm.

Cooley, R.L., and R.L. Naff, 1990, Regression modeling of ground-water flow: U. S. Geological Survey Techniques in Water-Resources Investigations, book 3, chap, B4, 232 p., http://pubs.er.usgs.gov/publication/twri03B4.

Croft, M.G., 1972, Subsurface geology of the late Tertiary and Quaternary water-bearing deposits of the southern part of the San Joaquin Valley, California: U.S. Geological Survey Water-Supply Paper 1999-H, 29 p., http://pubs.er.usgs.gov/publication/wsp1999H.

Davids Engineering, Inc., 2012, South San Joaquin Irrigation District Agricultural Water Management Plan, December 2012, variously paginated, http://www.ssjid.com/ assets/pdf/2012-Ag-Water-Management-Plan.pdf.

Davis, G.H., Green, J.H., Olmsted, F.H., and Brown, D.W., 1959, Ground-water conditions and storage capacity in the San Joaquin Valley, California: U.S. Geological Survey Water-Supply Paper 1469, 287 p., http://pubs.er.usgs.gov/publication/wsp1469. 
Davis, S.N. and Hall, F.R., 1959, Water-quality of eastern Stanislaus and northern Merced counties, California: Palo Alto, Calif., Stanford University Publications, Geological Sciences, v. 6, no. 1, 112 p.

Domagalski, J., Phillips, S., Bayless, R., Zamora, Celia, Kendall, C., Wildman, R., and Hering, J., 2008, Influences of the unsaturated, saturated, and riparian zones on the transport of nitrate near the Merced River, California, USA: Hydrogeology Journal, v. 16, no. 4, p. 675-690, http://dx.doi.org/10.1007/s10040-007-0266-x.

Faunt, C.C., ed., 2009, Groundwater Availability of the Central Valley Aquifer, California: U.S. Geological Survey Professional Paper 1766, 227 p., http://pubs.er.usgs.gov/publication/pp1766.

Faunt, C.C., Belitz, Kenneth, and Hanson, R.T., 2010, Development of a three-dimensional model of sedimentary texture in valley-fill deposits of Central Valley, California, USA: Hydrogeology Journal, v. 18, no. 3, p. 625-649, http://dx.doi.org/10.1007/s10040-009-0539-7.

Gibeault, V.A., Cocker-ham, S., Henry, J.M., and Meyer, J., 1989, California turfgrass: Its use, water requirement, and irrigation: University of California Cooperative Extension, California Turfgrass Culture, v. 39, no. 3 and 4, https://agops.ucr.edu/turf/publications/ctc/ctc39_34.pdf.

Gronberg, J.M., Dubrovsky, N.M., Kratzer, C.R., Domagalski, J.L., Brown, L.R., and Burow, K.R., 1998, Environmental setting of the San Joaquin-Tulare Basins, California: U.S. Geological Survey WaterResources Investigations Report 97-4205, 45 p., http://pubs.er.usgs.gov/publication/wri974205.

Hanson, B.R., and Bendixen, Warren, 2004, Drip irrigation evaluated in Santa Maria Valley strawberries: California Agriculture, v. 58, no. 1, p. 48-53, http://dx.doi.org/10.3733/ca.v058n01p48.

Hanson, R.T., Boyce, S.E., Schmid, Wolfgang, Hughes, J.D., Mehl, S.M., Leake, S.A., Maddock, Thomas, III, and Niswonger, R.G., 2014, One-Water Hydrologic Flow Model (MODFLOW-OWHM): U.S. Geological Survey Techniques and Methods 6-A51, 120 p., http://dx.doi.org/10.3133/tm6A51.

Harbaugh, A.W., 2005, MODFLOW-2005-The U.S. Geological Survey modular ground-water modelThe ground-water flow process: U.S. Geological Survey Techniques and Methods 6-A16, variously paged, http://pubs.er.usgs.gov/publication/tm6A16.

Hargreaves, G.H. and Samani, Z.A., 1982, Estimating potential evapotranspiration: American Society of Civil Engineers, Journal of the Irrigation and Drainage Division, v. 108 , no. 3, p. 225-230, http://cedb.asce.org/cgi/WWWdisplay.cgi?35047.
Hargreaves, G.H. and Samani, Z.A., 1985, Reference crop evapotranspiration from temperature: Applied Engineering in Agricultural, vol. 1, no. 2, p. 96-99, http://dx.doi.org/10.13031/2013.26773.

Hill, M.C., and Tiedeman, C.R., 2007, Effective groundwater model calibration - With analysis of data, sensitivities, predictions, and uncertainty: New Jersey, John Wiley \& Sons, Inc., 480 p.

Jennings, C.W., 1977, Geologic map of California: California Department of Conservation, Division of Mines and Geology, Geologic Data Map No. 2, scale 1:750,000.

Johnson, A.I., 1967, Specific yield-Compilation of specific yields for various materials: U.S. Geological Survey Water-Supply Paper 1662-D, 74 p., http://pubs.er.usgs.gov/publication/wsp1662D.

Johnson, A.I., Moston, R.P., and Morris, D.A., 1968, Physical and hydrologic properties of water-bearing deposits in subsiding areas in central California: U.S. Geological Survey Professional Paper 497-A, 71 p., http://pubs.er.usgs.gov/publication/pp497A.

Laudon, J., and Belitz, Kenneth, 1991, Texture and depositional history of late Pleistocene-Holocene alluvium in the central part of the western San Joaquin Valley, California: Bulletin of the Association of Engineering Geologists, v. 28, no. 1, p. 73-88, http://dx.doi.org/10.2113/gseegeosci.xxviii.1.73.

Londquist, C.J., 1981, Digital model of the unconsolidated aquifer system in the Modesto area, Stanislaus and San Joaquin counties, California: U.S. Geological Survey Water-Resources Investigations Report 81-12, 36 p., http://pubs.er.usgs.gov/publication/wri8112.

Marchand, D.E., and Allwardt, Alan, 1981, Late Cenozoic stratigraphic units, northeastern San Joaquin Valley, California: U.S. Geological Survey Bulletin 1470, 70 p., http://pubs.er.usgs.gov/publication/b1470.

Modesto Irrigation District, 1999, Water management plan for the Modesto Irrigation District: July 13, 1999, variously paginated, http://www.mid.org/water/irrigation/ WaterManagementPlan_1999.pdf.

National Oceanic and Atmospheric Administration, 2005, California precipitation data, accessed November 14, 2005, at http://lwf.ncdc.noaa.gov/oa/pub/data/coop-precip/ california.txt.

Niswonger, R.G. and Prudic, D.E., 2005, Documentation of the Streamflow-Routing (SFR2) package to include unsaturated flow beneath streams-A modification to SFR1: U.S. Geological Survey Techniques and Methods 6-A13, 51 p., http://pubs.er.usgs.gov/publication/tm6A13. 
Page, R.W., 1986, Geology of the fresh groundwater basin of the Central Valley, California, with texture maps and sections: U.S. Geological Survey Professional Paper 1401-C, 54 p., http://pubs.er.usgs.gov/publication/pp1401C.

Page, R.W., and Balding, G.O., 1973, Geology and quality of water in the Modesto-Merced area, San Joaquin Valley, California: U.S. Geological Survey WaterResources Investigations Report 73-6, 98 p., http://pubs.er.usgs.gov/publication/wri736.

Phillips, S.P. and Belitz, Kenneth, 1991, Calibration of a texture-based model of a ground-water flow system, western San Joaquin Valley, California: Ground Water, v. 29 , no. 5, p. 702-715., http://dx.doi.org/10.1111/j.1745-6584.1991.tb00562.x.

Phillips, S.P., Beard, Sherrill, and Gilliom, R.J., 1991, Quantity and quality of ground-water inflow to the San Joaquin River, California: U.S. Geological Survey Water-Resources Investigations Report 91-4019, 64 p., http://pubs.er.usgs.gov/publication/wri914019.

Phillips, S.P., Green, C.T., Burow, K.R., Shelton, J.L., and Rewis, D.L., 2007, Simulation of multiscale groundwater flow in part of the northeastern San Joaquin Valley, California: U.S. Geological Survey Scientific Investigations Report 2007-5009, 43 p., http://pubs.er.usgs.gov/publication/sir20075009.

Piper, A.M., Gale, H.S., Thomas, H.E., and Robinson, T.W., 1939, Geology and ground-water hydrology of the Mokelumne area, California: U.S. Geological Survey Water-Supply Paper 780, 230 p., http://pubs.er.usgs.gov/publication/wsp780.

Schmid, Wolfgang, and Hanson, R.T., 2009, The Farm Process Version 2 (FMP2) for MODFLOW-2005Modifications and upgrades to FMP1: U.S. Geological Survey Techniques and Methods Report 6-A32, http://pubs.er.usgs.gov/publication/tm6A32.

Schmid, Wolfgang, Hanson, R.T., Maddock III, Thomas, and Leake, S.A., 2006, User's guide for the Farm Process (FMP1) for the U.S. Geological Survey's modular three-dimensional finite-difference ground-water flow model, MODFLOW-2000: U.S. Geological Survey Techniques and Methods 6-A17, 127 p., http://pubs.er.usgs.gov/publication/tm6A17.
Sheets, R.A., Hill, M.C., Haitjema, H.M., Provost, A.M., and Masterson, J.P., 2015, Simulation of water-table aquifers using specified saturated thickness: Groundwater, v. 53 no. 1, p. 151-157., http://dx.doi.org/10.1111/gwat.12164.

Sneed, Michelle, Brandt, Justin, and Solt, Mike, 2013, Land subsidence along the Delta-Mendota Canal in the northern part of the San Joaquin Valley, California, 2003-10: U.S. Geological Survey Scientific Investigations Report 2013-5142, 86 p., http://dx.doi.org/10.3133/sir20135142.

Snyder, R.L., Lanini, B.J., Shaw, D.A., and Pruitt, W.O., 1987, Using reference evapotranspiration (ETo) and crop coefficients to estimate crop evapotranspiration $(E T c)$ for agronomic crops, grasses, and vegetable crops: University of California Cooperative Extension Leaflet 21427, 12 p., http://lawr.ucdavis.edu/irrigation/irrigation_leaflets/L21427. html.

Watermark Numerical Computing, 2005, PEST ModelIndependent Parameter Estimation User Manual, 5th Edition, 333 p., retrieved from http://www.pesthomepage. org/getfiles.php?file=pestman.pdf.

Watermark Numerical Computing, 2010, Windows BEOPEST:, 7p., retrieved from http://www.pesthomepage. org/getfiles.php?file=windows_beopest.doc.

Williamson, A.K., Prudic, D.E., and Swain, L.A., 1989, Ground-water flow in the Central Valley, California: U.S. Geological Survey Professional Paper 1401-D, 127 p., http://pubs.er.usgs.gov/publication/pp1401D.

Zamora, Celia, 2006, Estimating rates of exchange across the sediment/water interface in the lower Merced River, CA: California State University, Sacramento, M.S. thesis, 110 p.

Zamora, Celia, Dahlgren, R.A., Kratzer, C.R., Downing, B.D., Russell, A.D., Dileanis, P.D., Bergamaschi, B.A., and Phillips, S.P., 2013, Groundwater contributions of flow, nitrate, and dissolved organic carbon to the lower San Joaquin River, California, 2006-08: U.S. Geological Survey Scientific Investigations Report 2013-5151, 105 p., http://dx.doi.org/10.3133/sir20135151. 
Publishing support provided by the U.S. Geological Survey

Science Publishing Network, Sacramento Publishing Service Center

For more information concerning the research in this report, contact the Director, California Water Science Center

U.S. Geological Survey

6000 J Street, Placer Hall

Sacramento, California 95819

http://ca.water.usgs.gov 



\section{$\frac{\mathbb{2}}{3}$}

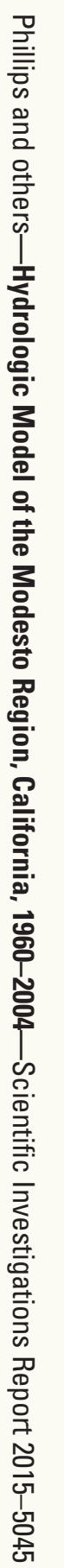

